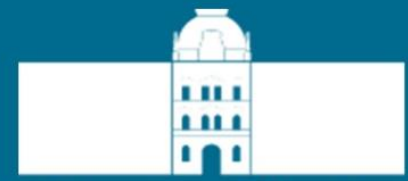

University of Maribor

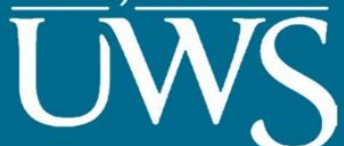

\title{
$10^{\mathrm{TH}}$ International Conference on Sustainable Energy and Environmental Protection:
}

\section{Waste Energy and Management}

\author{
(June 27 ${ }^{\mathrm{TH}}-30^{\mathrm{TH}}, 2017$, Bled, Slovenia)
}

(Conference Proceedings)

Editors:

Emeritus Prof. dr. Jurij Krope

Prof. dr. Abdul Ghani Olabi

Prof. dr. Darko Goričanec

Prof. dr. Stanislav Božičnik 
University of Maribor Press 


\title{
$10^{\mathrm{TH}}$ International Conference on Sustainable Energy and Environmental Protection
}

\author{
Waste Energy and Management \\ (June $27^{\mathrm{TH}}-30^{\mathrm{TH}}, 2017$, Bled, Slovenia) \\ (Conference Proceedings)
}

Editors:

Emeritus Prof. dr. Jurij Krope

Prof. dr. Abdul Ghani Olabi

Prof. dr. Darko Goričanec

Prof. dr. Stanislav Božičnik 
Title: $\quad 10^{\mathrm{TH}}$ International Conference on Sustainable Energy and Environmental Protection (June $27^{\mathrm{TH}}-30^{\mathrm{TH}}, 2017$, Bled, Slovenia) (Conference Proceedings)

Subtitle: Waste Energy and Management

Editors: Emeritus Prof. Jurij Krope, Ph.D. (University of Maribor, Slovenia), Prof. Abdul Ghani Olabi, Ph.D. (University of the West of Scotland, UK), Asso. Prof. Darko Goričanec, Ph.D. (University of Maribor, Slovenia), Asso. Prof. Stanislav Božičnik (University of Maribor, Slovenia).

Review: Prof. Željko Knez, Ph.D. (University of Maribor, Slovenia), Prof. Niko Samec, Ph.D. (University of Maribor, Slovenia).

Tehnical editors : Jan Perša (University of Maribor Press), Armin Turanović (University of Maribor Press).

Design and layout: University of Maribor Press

Conference: $\quad 10^{\mathrm{TH}}$ International Conference on Sustainable Energy and Environmental Protection

Honorary Committee:

Abdul Ghani Olabi, Ph.D. (Honorary President, University of the West of Scotland, United Kingdom), Igor Tičar, Ph.D (Rector of the University of Maribor, Slovenia), Niko Samec $\mathrm{Ph} . D$. (Pro-rector of University of Maribor, Slovenia), Zdravko Kravanja, Ph-D. (Dean of the Faculty of Chemistry and Chemical Engineering, University of Maribor, Slovenia).

Organising Committee:

Jurij Krope, Ph.D. (University of Maribor, Slovenia), Darko Goričanec, Ph.D. (University of Maribor, Slovenia), Stane Božičnik, Ph.D. (University of Maribor, Slovenia), Peter Trop, Ph.D. (University of Maribor, Slovenia), Danijela Urbancl, Ph.D. (University of Maribor, Slovenia), Sonja Roj (University of Maribor, Slovenia), Željko Knez, Ph.D. (University of Maribor, Slovenia), Bojan Štumberger, Ph.D. (University of Maribor, Slovenia), Franci Čuš, Ph.D. (University of Maribor, Slovenia), Miloš Bogataj, Ph.D. (University of Maribor, Slovenia), Janez Žlak, Ph.D (Mine Trbovlje Hrastnik, Slovenia), LL. M. Tina Žagar (Ministry of Economic Development and Technology), Igor Ivanovski, MSc. (IVD Maribor, Slovenia), Nuša Hojnik, Ph.D. (Health Center Maribor).

Programme Committee:

Prof. Abdul Ghani Olabi (UK), Emeritus Prof. Jurij Krope (Slovenia), Prof. Henrik Lund (Denmark), Prof. Brian Norton (Ireland), Prof. Noam Lior (USA), Prof. Zdravko Kravanja (Slovenia), Prof. Jirí Jaromír Klemeš (Hungary), Prof. Stane Božičnik (Slovenia), Prof. Bojan Štumberger (Slovenia), Prof. Soteris Kalogirou (Cyprus), Prof. Stefano Cordiner (Italy), Prof. Jinyue Yan (Sweden), Prof. Umberto Desideri (Italy), Prof. M.S.J. Hashmi (Ireland), Prof. Michele Dassisti (Italy), Prof. Michele Gambino (Italy), Prof. S. Orhan Akansu (Turkey), Dr. David Timoney (Ireland), Prof. David Kennedy (Ireland), Prof. Bekir Sami Yilbas (Saudi Arabia), Dr. Brid Quilty (Ireland), Prof. B. AbuHijleh (UAE), Prof. Vincenc Butala (Slovenia), Prof. Jim McGovern (Ireland), Prof. Socrates Kaplanis (Greece), Dr. Hussam Jouhara (UK), Prof. Igor Tičar (Slovenia), Prof. Darko Goričanec (Slovenia), Dr. Joseph Stokes (Ireland), Prof. Antonio Valero (Spain), Prof. Aristide F. Massardo (Italy), Prof. Ashwani Gupta (USA), Dr. Aoife Foley (UK), Dr. Athanasios Megartis (UK), Prof. Francesco Di Maria (Italy), Prof. George Tsatsaronis (Germany), Prof. Luis M. Serra (Spain), Prof. Savvas Tassou (UK), Prof. Luigi Alloca (Italy), Prof. Faek Diko (Germany), Dr. F. Al-Mansour (Slovenia), Dr. Artur Grunwald (Germany), Dr. Peter Trop (Slovenia), Prof. Philippe Knauth (France), Prof. Paul Borza (Romania), Prof. Roy Douglas (UK), Prof. Dieter Meissner (Austria), Dr. Danijela Urbancl (Slovenia), Prof. Daniel Favrat (Switzerland), Prof. Erik Dahlquist (Sweden), Prof. Eric Leonhardt (USA), Prof. GianLuca Rospi (Italy), Prof. Giuseppe Casalino (Italy), Prof. J. Dawson (USA), Dr. Josè Simoes (Portugal), Prof. Kadir Aydin (Turkey), Dr. Khaled Benyounis (Ireland), Prof. Laszlo Garbai (Hungary), Prof. Mariano Martin (Spain), Prof. Masahiro Ishida (Japan), Prof. Michael Seal (USA), Prof. Marco Spinedi (Italy), Prof. Michio Kitano (Japan), Prof. Milovan Jotanović (BiH), Prof. Nafiz Kahraman (Turkey), Prof. Na Zhang (China), Prof. Naotake Fujita (Japan), Prof. Niko Samec (Slovenia), Prof. Oleksandr Zaporozhets (Ukraine), Prof. Osama Al-Hawaj (Kuwait), Prof. Petar Varbanov (Hungary), Prof. Peter Goethals (Belgium), Prof. Qi Zhang (China), Prof. Rik Baert (The Netherlands), Prof. Rolf Ritz (USA), Dr. Stephen Glover (UK), Prof. Signe Kjelstrup (Norway), Dr. Sumsun Naher (UK), Prof. Sven Andersson (Sweden), Dr. Salah Ibrahim (UK), Prof. Sebahattin Unalan (Turkey), Prof. Sabah Abdul-Wahab Sulaiman (Oman), Prof. Somrat Kerdsuwan (Thailand), Prof. T. Hikmet Karakoç (Turkey), Prof. Tahir Yavuz (Turkey), Prof. Hon Loong Lam (Thailand), LL.M. Tina Žagar (Slovenia), Prof. A.M.Hamoda (Qatar), Prof. Gu Hongchen (China), Prof. Haşmet Turkoglu (Turkey), Dr. Hussam Achour (Ireland), Dr. James Carton (Ireland), Dr. Eivind Johannes (Norway), Prof. Elvis Ahmetović (BiH), Prof. 
D.G.Simeonov (Bulgaria), Prof. Abdelakder Outzourhit (Morocco), Prof. Bilge Albayrak Çeper (Turkey), Prof. Bekir Zühtü Uysal (Turkey), Prof. D. Bradley (UK), Dr. Silvia Tedesco (UK), Dr. Valentin Ivanov (Germany), Dr. Vincent Lawlor (Austria), Prof. Yonghua Cheng (Belgium), Prof. Yasufumi Yoshimoto (Japan), Prof. Yahya Erkan Akansu (Turkey), Prof. Yunus Ali Çengel (Turkey), Prof. Zeljko Knez (Slovenia), Prof. Zoltan Magyar (Hungary), Dr. William Smith (Ireland), Dr. Abed Alaswad (UK).

First published in 2017 by

University of Maribor Press

Slomškov trg 15, 2000 Maribor, Slovenia

tel. +386225042 42, fax +38622523245

http://press.um.si, zalozba@um.si

\section{Co-published by}

University of Maribor, Faculty of Chemistry and Chemical Engineering

Smetanova ulica 17,2000 Maribor, Slovenia

tel. +386 (0)2 2294 400, faks + $386(0) 22527774$

http://www.fkkt.um.si, fkkt@um.si

Published: 5. July 2017

\section{(C) University of Maribor Press}

All rights reserved. No part of this book may be reprinted or reproduced or utilized in any form or by any electronic, mechanical, or other means, now known or hereafter invented, including photocopying and recording, or in any information storage or retrieval system, without permission in writing from the publisher.

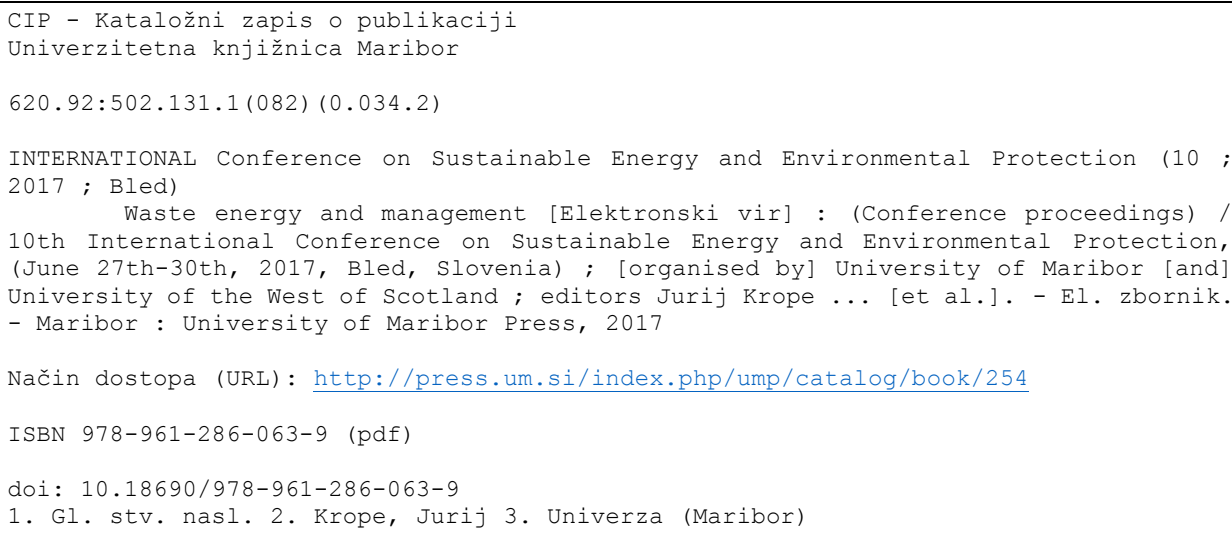

ISBN 978-961-286-063-9

DOI: https://doi.org/10.18690/978-961-286-063-9

Price: Free copy

For publisher: $\quad$ Prof. Igor Tičar, Ph.D., rector (University of Maribor) 
$10^{\mathrm{TH}}$ InTERNATIONAL CONFERENCE ON Sustainable ENERGy AND

EnVironmental Protection (June $27^{\mathrm{TH}}-30^{\mathrm{TH}}$, 2017, Bled,

Slovenia), WASte ENERGY AND MANAGEMENT

J. Krope, A.Ghani Olabi, D. Goričanec \& S. Božičnik

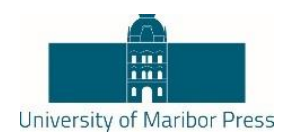

\section{Preface}

The $10^{\text {th }}$ International Conference on Sustainable Energy and environmental Protection SEEP 2017 was organised on June $27^{\text {th }}-30^{\text {th }} 2017$ in Bled, Slovenia, by:

- Faculty of Chemistry and Chemical Engineering, University of Maribor, Slovenia,

- University of the West of Scotland, School of Engineering and

The aim of SEEP2017 is to bring together the researches within the field of sustainable energy and environmental protection from all over the world.

The contributed papers are grouped in 18 sessions in order to provide access to readers out of 300 contributions prepared by authors from 52 countries.

We thank the distinguished plenary and keynote speakers and chairs who have kindly consented to participate at this conference. We are also grateful to all the authors for their papers and to all committee members.

We believe that scientific results and professional debates shall not only be an incentive for development, but also for making new friendships and possible future scientific development projects.

General chair

Emeritus Prof. dr. Jurij Krope
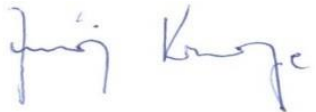
$10^{\mathrm{TH}}$ International CONFERENCE ON Sustainable ENERGY AND Environmental Protection (June $27^{\mathrm{TH}}-30^{\mathrm{TH}}$, 2017, BLed, Slovenia), Waste ENERGy AND Management J. Krope, A.Ghani Olabi, D. Goričanec \& S. Božičnik

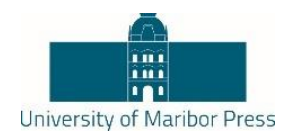

\title{
Plenary Talk on \\ The Relation between Renewable Energy and Circular Economy
}

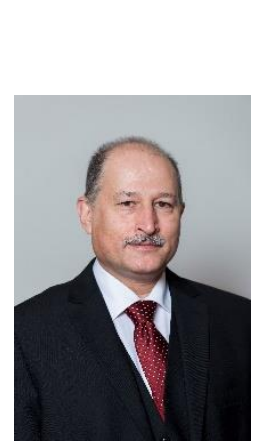

\author{
ABDUL GHANI OLABI - BIBLIOGRAPHY
}

Prof Olabi is director and founding member of the Institute of Engineering and Energy Technologies (www.uws.ac.uklieet) at the University of the West of Scotland. He received his M.Eng and Ph.D. from Dublin City University, since 1984 he worked at SSRC, HIAST, CNR, CRF, DCU and UWS. Prof Olabi has supervised postgraduate research students (10 M.Eng and 30PhD) to successful completion. Prof Olabi has edited 12 proceedings, and has published more than 135 papers in peer-reviewed international journals and about 135 papers in international conferences, in addition to 30 book chapters. In the last 12 months Prof Olabi has patented 2 innovative projects. Prof Olabi is the founder of the International Conference on Sustainable Energy and Environmental Protection SEEP, www.seepconference.co.uk

$\mathrm{He}$ is the Subject Editor of the Elsevier Energy Journal https://www.journals.elsevier.com/energy/editorial-board/abdul-ghani-olabi, also Subject editor of the Reference Module in Materials Science and Materials Engineering http://scitechconnect.elsevier.com/reference-module-material-science/ and board member of a few other journals. Prof Olabi has coordinated different National, EU and International Projects. He has produced different reports to the Irish Gov. regarding: Hydrogen and Fuel Cells and Solar Energy.

Correspondence AdDress: Abdul Ghani Olabi, Ph.D., Professor, University of the West of Scotland, School of Engineering and Computing, D163a, McLachlan Building, Paisley, United Kingdom, e-mail: Abdul.Olabi@uws.ac.uk. 
$10^{\text {TH }}$ InTERNATIONAL CONFERENCE ON Sustainable ENERGy AND

Environmental Protection (June 27 $7^{\mathrm{TH}}-30^{\mathrm{TH}}$, 2017, Bled,

Slovenia), Waste ENERGy AND Management

J. Krope, A.Ghani Olabi, D. Goričanec \& S. Božičnik

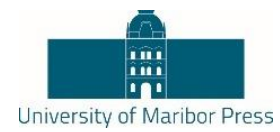

\title{
Plenary Talk on \\ Energy Footprints Reduction and Virtual Footprints Interactions
}

\author{
JIŘí JAROMÍR KLEMEŠ \& PETAR SABEV VARBANOV
}

Increasing efforts and resources have been devoted to research during environmental studies, including the assessment of various harmful impacts from industrial, civic, business, transportation and other economy activities. Environmental impacts are usually quantified through Life Cycle Assessment (LCA). In recent years, footprints have emerged as efficient and useful indicators to use within LCA. The footprint assessment techniques has provided a set of tools enabling the evaluation of Greenhouse Gas (GHG) - including $\mathrm{CO}_{2}$, emissions and the corresponding effective flows on the world scale. From all such indicators, the energy footprint represents the area of forest that would be required to absorb the GHG emissions resulting from the energy consumption required for a certain activity, excluding the proportion absorbed by the oceans, and the area occupied by hydroelectric dams and reservoirs for hydropower.

An overview of the virtual GHG flow trends in the international trade, associating the GHG and water footprints with the consumption of goods and services is performed. Several important indications have been obtained: (a) There are significant GHG gaps between producer's and consumer's emissions - US and EU have high absolute net imports GHG budget. (b) China is an exporting country and increasingly carries a load of GHG emission and virtual water export associated with consumption in the relevant importing countries. (c) International trade can reduce global environmental pressure by redirecting import to products produced with lower intensity of GHG emissions and lower water footprints, or producing them domestically.

To develop self-sufficient regions based on more efficient processes by combining neighbouring countries can be a promising development. A future direction should be focused on two main areas: (1) To provide the self-sufficient regions based on more efficient processes by combining production of surrounding countries. (2) To develop the shared mechanism and market share of virtual carbon between trading partners regionally and internationally.

CORRESPONDENCE ADDRESS: Jiří Jaromír Klemeš, DSc, Professor, Brno University of Technology - VUT Brno, Faculty of Mechanical Engineering, NETME Centre, Sustainable Process Integration Laboratory - SPIL, Technická 2896/2, $616 \quad 69$ Brno, Czech Republic, e-mail: klemes@fme.vutbr.cz. Petar Sabev Varbanov, Ph.D., Associate Professor, Brno University of Technology - VUT Brno, Faculty of Mechanical Engineering, NETME Centre, Sustainable Process Integration Laboratory - SPIL, Technická 2896/2, 61669 Brno, Czech Republic, e-mail: varbanov@fme.vutbr.cz. 
$10^{\mathrm{TH}}$ International CONFERENCE ON Sustainable ENERGY AND Environmental Protection (June 27 $7^{\mathrm{TH}}-30^{\mathrm{TH}}$, 2017, Bled, Slovenia), Waste ENERGy AND Management

J. Krope, A.Ghani Olabi, D. Goričanec \& S. Božičnik

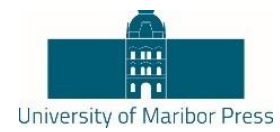

\section{JIŘÍ JAROMÍR KLEMEŠ - BIBLIOGRAPHY}

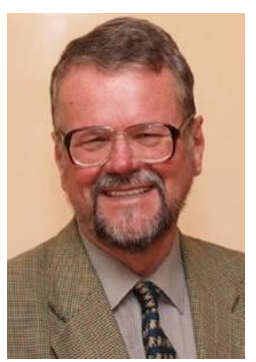

Head of "Sustainable Process Integration Laboratory - SPIL", NETME Centre, Faculty of Mechanical Engineering, Brno University of Technology - VUT Brno, Czech Republic and Emeritus Professor at "Centre for Process Systems Engineering and Sustainability", Pázmány Péter Catholic University, Budapest, Hungary.

Previously the Project Director, Senior Project Officer and Hon Reader at Department of Process Integration at UMIST, The University of Manchester and University of Edinburgh, UK. Founder and a long term Head of the Centre for Process Integration and Intensification - CPI2, University of Pannonia, Veszprém, Hungary. Awarded by the EC with Marie Curies Chair of Excellence (EXC). Track record of managing and coordinating 91 major EC, NATO and UK Know-How projects. Research funding attracted over $21 \mathrm{M€}$.

Co-Editor-in-Chief of Journal of Cleaner Production ( $\mathrm{IF}=4.959)$. The founder and President for 20 $\mathrm{y}$ of PRES (Process Integration for Energy Saving and Pollution Reduction) conferences. Chairperson of CAPE Working Party of EFCE, a member of WP on Process Intensification and of the EFCE Sustainability platform.

He authored nearly 400 papers, h-index 40. A number of books published by McGraw-Hill; Woodhead; Elsevier; Ashgate Publishing Cambridge; Springer; WILEY-VCH; Taylor \& Francis).

Several times Distinguished Visiting Professor for Universiti Teknologi Malaysia, Xi'an Jiaotong University; South China University of Technology, Guangzhou; Tianjin University in China; University of Maribor, Slovenia; University Technology Petronas, Malaysia; Brno University of Technology and the Russian Mendeleev University of Chemical Technology, Moscow. Doctor Honoris Causa of Kharkiv National University "Kharkiv Polytechnic Institute" in Ukraine, the University of Maribor in Slovenia, University POLITEHNICA Bucharest, Romania. "Honorary Doctor of Engineering Universiti Teknologi Malaysia", "Honorary Membership of Czech Society of Chemical Engineering", "European Federation of Chemical Engineering (EFCE) Life-Time Achievements Award" and "Pro Universitaire Pannonica" Gold Medal.

CORRESPONDENCE AdDRESS: Jiří Jaromír Klemeš, DSc, Professor, Brno University of Technology - VUT Brno, Faculty of Mechanical Engineering, NETME Centre, Sustainable Process Integration Laboratory - SPIL, Technická 2896/2, 61669 Brno, Czech Republic, e-mail: klemes@fme.vutbr.cz. 
$10^{\mathrm{TH}}$ InTERNATIONAL CONFERENCE ON Sustainable ENERGy AND

Environmental Protection (June 27 $7^{\mathrm{TH}}-30^{\mathrm{TH}}$, 2017, Bled,

Slovenia), Waste ENERGy AND Management

J. Krope, A.Ghani Olabi, D. Goričanec \& S. Božičnik

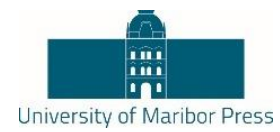

\title{
Plenary Talk on \\ Renewable energy sources for environmental protection
}

\author{
HAKAN SERHAD SOYHAN
}

Development in energy sector, technological advancements, production and consumption amounts in the countries and environmental awareness give shape to industry of energy. When the dependency is taken into account in terms of natural resources and energy, there are many risks for countries having no fossil energy sources. Renewable and clean sources of energy and optimal use of these resources minimize environmental impacts, produce minimum secondary wastes and are sustainable based on current and future economic and social societal needs. Sun is one of the main energy sources in recent years. Light and heat of sun are used in many ways to renewable energy. Other commonly used are biomass and wind energy. To be able to use these sources efficiently national energy and natural resources policies should be evaluated together with the global developments and they should be compatible with technological improvements. Strategic plans with regard to energy are needed more intensively and they must be in the qualification of a road map, taking into account the developments related to natural resources and energy, its specific needs and defining the sources owned by countries. In this presentation, the role of supply security was evaluated in term of energy policies. In this talk, new technologies in renewable energy production will be shown and the importance of supply security in strategic energy plan will be explained.

Correspondence Address: Hakan Serhad Soyhan, Ph.D., Professor, Sakarya University, Engineering Faculty, Esentepe Campus, M7 Building, 54187 - Esentepe /Sakarya, Turkey, e-mail: hsoyhan@sakarya.edu.tr. 
$10^{\mathrm{TH}}$ InTERNATIONAL CONFERENCE ON Sustainable ENERGY AND Environmental Protection (June 27 $7^{\mathrm{TH}}-30^{\mathrm{TH}}$, 2017, Bled, SLOVENia), WASTE ENERGY AND MANAGEMENT

J. Krope, A.Ghani Olabi, D. Goričanec \& S. Božičnik

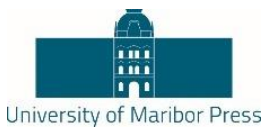

\section{HAKAN SERHAD SOYHAN - BIBLIOGRAPHY}

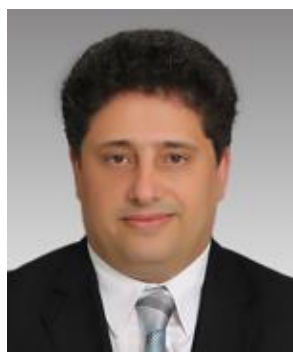

Professor at Sakarya University, Engineering Faculty. $50 \%$ fot teaching and the rest for reasearch activities.

Teaching, courses taught:

Graduate courses:

- Combustion technology;

- Modelling techniques;

Undergraduate courses:

- Combustion techniques;

- Internal combustion engines;

- Fire safety.

Tehnical skills and competences professional societies:

- 25 jurnal papers in SCI Index. 23 conference papers;

- $\quad$ Editor at FCE journal. Co-editor at J of Sakarya University;

- Head of Local Energy Research Society (YETA);

- Member od American Society of Mechanical engineers (ASME);

- Member of Turkish Society of Mechanical Engineers (TSME).

Correspondence AdDress: Hakan Serhad Soyhan, Ph.D., Professor, Sakarya University, Engineering Faculty, Esentepe Campus, M7 Building, 54187 - Esentepe /Sakarya, Turkey, e-mail: hsoyhan@sakarya.edu.tr. 

$10^{\mathrm{TH}}$ InTERnAtional CONFERENCE ON Sustainable ENERGy AND Environmental Protection (June $27^{\mathrm{TH}}-30^{\mathrm{TH}}$, 2017, Bled, Slovenia), WASTE ENERGY AND MANAGEMENT

J. Krope, A.Ghani Olabi, D. Goričanec \& S. Božičnik

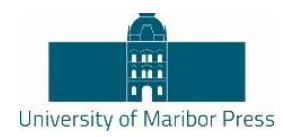

\section{Table of Contents}

\section{CONFERENCE PROCEEDINGS}

Study on the Comprehensive Utilization of City Kitchen Waste as a Resource in China

Hanxi Wang, Jianling Xu \& Lianxi Sheng

Heat Pipe Based Heat Exchanger for Clean Yerba Mate Drying Process

Hussam Jouhara, Theodora Nannou, Bertrand Delpech, Sulaiman Almahmoud, Amisha Chauhan, Mark Boocock, Luiz Wrobel, Ignacio Carrau \& Federico Carrau

Production of Diesel-Like Oil as Potential Fuel from Microwave-Assisted Pyrolysis of Waste Shipping Oil

Wan Adibah Wan Mahari, Nur Fatihah Zainuddin, Nyuk Ling Ma \& Su Shiung Lam

Numerical Simulation of Refuse-Derived Fuel ThermoChemical Conversion in a Waste-to-Energy Plant

Michela Costa, Christian Curcio, Daniele Piazzullo, Vittorio Rocco \& Raffaele Tuccillo

Waste Gasification with an Advanced 100 kW Dual Fluidized Bed Gasifier

Florian Benedikt, Johannes Christian Schmid \& Hermann Hofbauer

Performance Analysis of Heat Recovery System from Exhaust

Gases of Boiler

Mahmoud Khaleda, Mohamad Ramadan, Bakri Abed Alhay, Hisham Elhage \& Ahmad Haddad

Protection Of TEG Module at High Temperature Transient Boundary Condition Using Phase Change Materials, an Experimental Investigation

Saeed Ahmadi Atouei, Alireza Rezaniakolaei, Ali Akbar Ranjbar \& Lasse Aistrup Rosendahl 
ii $\mid 10^{\mathrm{TH}}$ International CONFERENCE ON Sustainable ENERGy and ENVIRONMENTAL Protection (June $27^{\mathrm{TH}}-30^{\mathrm{TH}}, 2017$, Bled, Slovenia), Waste Energy and MANAGEMENT

Table od Contents 
$10^{\mathrm{TH}}$ InTERnational CONFERENCE ON Sustainable ENERgy AND Environmental Protection (June 27 $7^{\mathrm{TH}}-30^{\mathrm{TH}}, 2017$, BLed, Slovenia), WASTE ENERGY AND MANAGEMENT

J. Krope, A.Ghani Olabi, D. Goričanec \& S. Božičnik

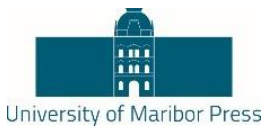

\title{
Study on the Comprehensive Utilization of City Kitchen Waste as a Resource in China
}

\author{
HANXI WANG, JIANLING XU \& LIANXI SHENG
}

\begin{abstract}
The amount of kitchen waste generated in China's cities is very large per capita, and processing technology is simple. Based on a data analysis, field investigation and experimental research, kitchen waste is acidic, has high moisture content, has high organic matter content, and has a high carbon to nitrogen $(\mathrm{C} / \mathrm{N})$ ratio. Complete kitchen waste resource utilization can be achieved through a comprehensive treatment technology consisting of pretreatment, wet solution, oil-water separation and mesophilic fermentation. Grease is extracted in a two-stage, oil-water separation system. Grease is then converted to ester by the two-step esterification reaction of acid-catalyzed pre-esterification and alkalicatalyzed transesterification. Vacuum distillation was used on the resulting ester to produce biodiesel.
\end{abstract}

Keywords: $\cdot$ kitchen waste $\cdot$ biodiesel $\bullet$ anaerobic digestion $\bullet$ biogas, grease •

CoRrespondence AdDRESS: Hanxi Wang, Northeast Normal University, State Environmental Protection Key Laboratory of Wetland Ecology and Vegetation Restoration/School of Environment, 5268 Renmin Street, Changchun, Jilin Province, China, e-mail: wanghanxizs1982@126.com. Jianling Xu, Normal University, State Environmental Protection Key Laboratory of Wetland Ecology and Vegetation Restoration/School of Environment, 5268 Renmin Street, Changchun, Jilin Province, China, e-mail: xujl@foxmail.com. Lianxi Sheng, Northeast Normal University, State Environmental Protection Key Laboratory of Wetland Ecology and Vegetation Restoration/School of Environment, 5268 Renmin Street, Changchun, Jilin Province, China, e-mail: shenglx@ neno.edu.cn. 
$10^{\text {TH }}$ INTERNATIONAL CONFERENCE ON SUSTAINABLE ENERGy AND ENVIRONMENTAL Protection (June $27^{\mathrm{TH}}-30^{\mathrm{TH}}, 2017$, Bled, SLOVEnia), WASte ENERGy AND MANAGEMENT

H. Wang, Jianling Xu \& L. Sheng: Study on the Comprehensive Utilization of City

Kitchen Waste as a Resource in China

Food waste is a mixture of various substances including oil, water, vegetables, rice, meat, plastic, and paper towels. Food waste is high in water, organic matter, oil and salt, and its seasonal composition varies greatly [1]. Kitchen waste is perishable, harbors parasites, eggs and pathogenic microorganisms, mycotoxins, and other harmful substances. Chinese kitchen waste composition is complex, accounting for approximately 30 to $50 \%$ of the total amount of household waste [2,3]. Kitchen waste is used in fuel production, including biodiesel, methane, hydrogen, and fuel ethanol [4].

Approximately 1.3 billion tons of kitchen waste is produced in the food supply chain every year, and this amount grows as the economy and population increase [5]. Analyses of the composition characteristics of food waste have found that kitchen waste has weak acidity with high protein content, is rich in organic matter, and has high utilization value [6]. A survey found that restaurants are the main source of kitchen waste; less than $50 \%$ of the food and beverage portion are separated; and the resource utilization rate is less than $30 \%[7,8]$. Due to the large amount of carbohydrate in the kitchen waste, it can be used to produce sugar and ethanol, which is a more important use than the landfilling, incineration and other disposal methods [9].

The main methods of kitchen waste disposal are landfilling, incineration, anaerobic fermentation, aerobic composting, direct drying as feed, wet solution, and microbial treatment technology. A large amount of kitchen waste is generated every day and is increasing in China. This research was launched to study the effectiveness of comprehensive utilization of kitchen food waste as a natural resource, to ensure food safety and improve the city environment, harmless kitchen waste treatment.

\section{$2 \quad$ Materials and methods}

\subsection{The content and per capita amount of city kitchen waste generated}

The amount of food waste is closely related to residential population; increasing urban population and economic development have increased the amount of food waste. According to our survey, current Chinese urban food waste production is $0.05 \sim 1.63$ $\mathrm{kg} / \mathrm{person} / \mathrm{day}$. According to the survey, China's annual food waste growth rate is 1.2 to $5.6 \%$. China's annual waste removal capacity reached 170.080 million $\mathrm{t}$, and the waste treatment rate reached $84.8 \%$, showing a rising trend [10]. Through the analysis of over 30 components of kitchen waste from a medium-sized Chinese city, the $\mathrm{pH}$ level of kitchen waste was 4.50 6.88, C/N was 15.24 20.12, and organic content (dry basis) was $38.75 \sim 90.08 \%$, as shown in Tables $1[2,4,5,7,8,11,12]$. 
$10^{\mathrm{TH}}$ INTERNATIONAL CONFERENCE ON SUSTAINABLE ENERGY AND ENVIRONMENTAL Protection (June $27^{\mathrm{TH}}-30^{\mathrm{TH}}, 2017$, Bled, Slovenia), WASte ENERGy AND

MANAGEMENT

H. Wang, Jianling Xu \& L. Sheng: Study on the Comprehensive Utilization of City

Kitchen Waste as a Resource in China

Table 1 Characteristics of kitchen waste

\begin{tabular}{|l|l|l|}
\hline Index & Range & Average \\
\hline Moisture Content (\%) & $39.84 \sim 85.35$ & 71.22 \\
\hline Salt content (\%) & $0.50 \sim 3.57$ & 1.56 \\
\hline Total sugar (\%) & $15.24 \sim 69.0$ & 41.15 \\
\hline Starch content (\%) & $13.3 \sim 50.27$ & 30.69 \\
\hline Fat (\%) & $0.90 \sim 32.59$ & 13.91 \\
\hline Protein (\%) & $3.96 \sim 24.10$ & 9.15 \\
\hline
\end{tabular}

\subsection{Research method}

A literature review, field investigations, and experiments were performed. Related information of kitchen waste was collected and analyzed. Kitchen waste in the different parts of current Chinese was sampled and determined.

\section{$3 \quad$ Results and discussion}

\subsection{Kitchen waste conventional treatment method}

\subsubsection{Anaerobic fermentation}

Anaerobic fermentation is a natural organic matter degradation process in an anaerobic environment, where microbial action decomposes organic matter, producing methane and carbon dioxide. Environmental factors include temperature, $\mathrm{pH}$ value and $\mathrm{C} / \mathrm{N}$ ratio. Through the study of anaerobic fermentation of kitchen waste, it was found that the kitchen waste was mixed with pig manure and straw, mixed with cow dung, mixed with fruit/vegetable waste, and the reaction system is stable in the anaerobic fermentation stage, and the amount of methane is higher than that of a single raw material [13-15]. Through the anaerobic fermentation of sludge and kitchen waste, it was found that the addition of residual sludge could adjust the concentration of $\mathrm{pH}$, ammonia nitrogen and VFA; regulation of the alkaline agent and the further fermentation of hydrogen production could increase methane production [16].

Considering a variety of factors, the medium temperature anaerobic fermentation is used more frequently. The main products of anaerobic fermentation are divided into biogas, biogas slurry, and biogas residue; and these are all used for the preparation of fuel, biological pesticides or liquid fertilizer, and fertilizer, respectively.

\subsubsection{Composting and feed processing technology}

The process of high-temperature composting means that under aerobic conditions, the microorganisms oxidize part of the absorbed organic matter into simple inorganic matter through their own life metabolic activity. Then, the microorganisms release the energy required for the biological growth activity and convert the other part of the organic matter 

Protection (June $27^{\mathrm{TH}}-30^{\mathrm{TH}}, 2017$, Bled, SLOVEnia), WASte ENERGy AND MANAGEMENT

H. Wang, Jianling Xu \& L. Sheng: Study on the Comprehensive Utilization of City Kitchen Waste as a Resource in China

into new cell material. Feeding treatment technology mainly uses a physical means to cook the kitchen waste through high temperature heating, drying, and an antivirus and salt removal process, finally producing the protein feed additive, recycled water, biogas and so on.

\subsubsection{Microbial biochemical treatment}

Microbial biochemical treatment technology is used to select the natural vitality and proliferation ability of high temperature compound microbial strains. In this processing equipment, and high-temperature fermentation is carried out on kitchen waste. Thus, all types of organic matter can degrade and transform. It was found that the use of mixed bacteria to carry out fermentation of solid food waste, while controlling for the substrate moisture content, fermentation temperature, fermentation time and the number of bacteria added, can significantly improve the crude protein content [17].

\subsection{Study on the comprehensive utilization of kitchen waste}

\subsubsection{Wet solution treatment and oil-water separation}

In the wet solution treatment, kitchen waste is subjected to high pressure and high heat treatment forming. The upper layer is an oil phase composed of vegetable and animal fats; the intermediate layer is an emulsion phase composed mainly of an organic suspension; the lower layer is a heavy matter precipitate phase, mainly dregs. After the wet solution treatment, the material is discharged into the static buffer tank. Then, the oil and water separation, anaerobic digestion and other advanced treatments are carried out according to the different physical characteristics of the oil phase, the emulsified phase and the precipitation phase. The oil water separation system is used to separate the oil, water and slag from the oil phase material after the wet solution and to extract the oil into the biodiesel refining system to produce biodiesel. The use of a two-stage oil and water separation system can extract the oil (Figure 1). 
H. Wang, Jianling Xu \& L. Sheng: Study on the Comprehensive Utilization of City

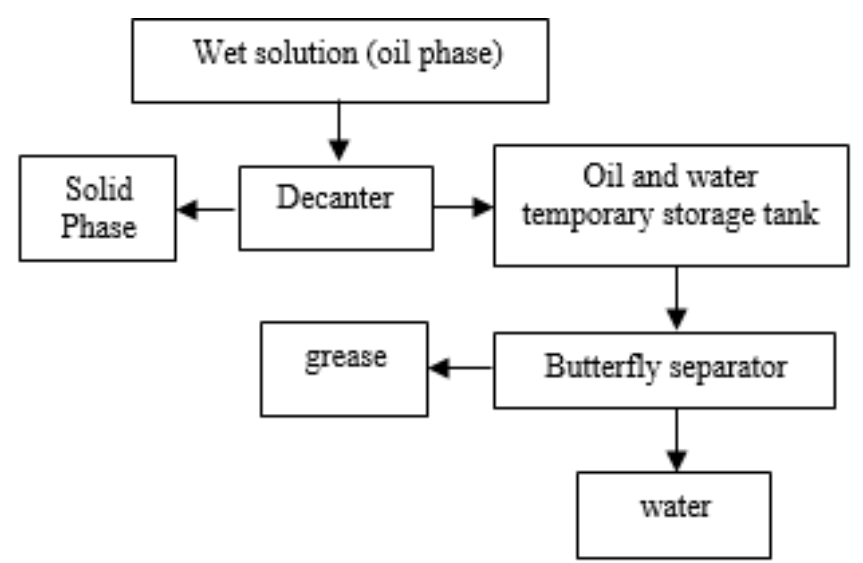

Figure 1 Biodiesel extraction process

\subsubsection{Biodiesel refining}

The esterification reaction is carried out in two steps for waste oil extracted from kitchen waste. The first is an acid catalytic pre-esterification reaction, and the second is an alkaline catalytic ester exchange reaction. Waste oils contain higher free fatty acids. When using alkaline catalysts, these free fatty acids easily form soap substances to prevent the separation of biodiesel from glycerol, and the use of acidic catalysts can avoid the formation of soapy substances. Therefore, for the production of biodiesel from waste oil, the first step is to use the acid catalyst to convert the free fatty acid into ester, and then use the basic catalyst to convert the triglycerides to esters. Biodiesel separation and purification is carried out through the separation of fatty acid methyl ester using gravity sedimentation followed by centrifugal separation.

\subsubsection{Anaerobic fermentation}

The anaerobic fermentation process uses anaerobic microorganisms to degrade the organic matter in kitchen waste under anaerobic conditions to produce methane, water, hydrogen, hydrogen sulfide and some small molecular compounds. Generally, the decomposition process of organic matter is divided into acid-producing stage and methane-producing stage. The acid-producing stage mainly hydrolyzes macromolecule organic matter into small molecule organic matter by the action of microorganism. The methanogenic phase is the substrate produced by acid production or hydrogen reaction to produce methane. The process flow is shown in Figure 2. 
$10^{\mathrm{TH}}$ INTERNATIONAL CONFERENCE ON SUSTAINABLE ENERGy AND ENVIRONMENTAL Protection (June $27^{\mathrm{TH}}-30^{\mathrm{TH}}, 2017$, Bled, SLovenia), WASte ENERGy AND MANAGEMENT

H. Wang, Jianling Xu \& L. Sheng: Study on the Comprehensive Utilization of City Kitchen Waste as a Resource in China

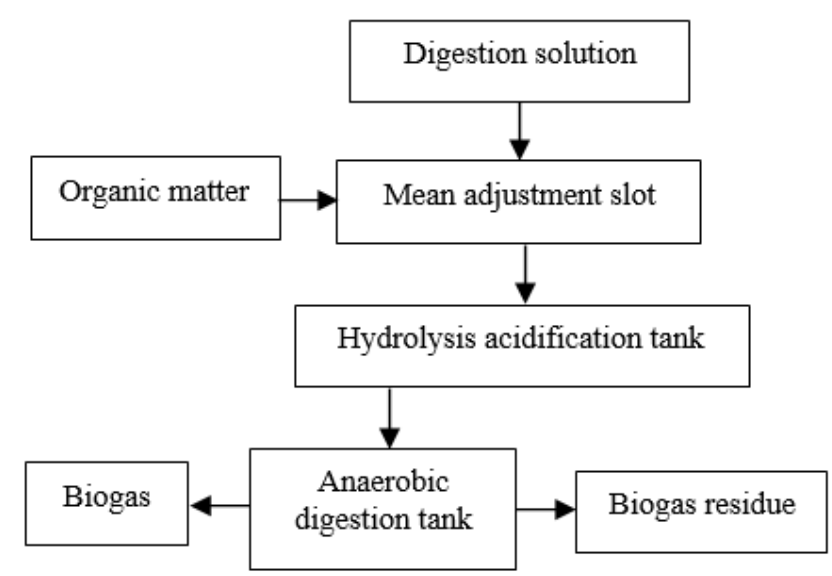

Figure 2. Anaerobic fermentation processes

In the anaerobic fermentation process, the material organic matter slurry first enters the homogeneous adjustment tank for homogeneous regulation, adjusting the solids rate to $8 \sim 12 \%$. Adding part of the reflux anaerobic digestion during homogenization process can ensure that the concentration of materials into the anaerobic fermentation tank remains consistent but can also have a vaccination effect. The homogenized material enters the hydrolytic acidification tank, and the macromolecule and the refractory organic material in the kitchen utensils in the hydrolytic acidification tank are degraded into small molecules and biodegradable organic matter. The hydrolysis acidification tank can play an important role in buffering and adjusting the $\mathrm{pH}$ value of in anaerobic fermentation tanks so that the fermentation material can stabilize the transition into methane production.

\section{Conclusion}

(1) Kitchen waste is acidic, has high water content, high organic matter content, high carbon-nitrogen ratio and is suitable for anaerobic fermentation.

(2) Through the analysis of the commonly used kitchen waste disposal methods, the comprehensive utilization of pretreatment, wet solution, oil-water separation and medium temperature fermentation, full resource utilization of kitchen waste can be achieved.

(3) Oil is converted to grease through the two-step esterification reaction. The first step is an acid catalytic pre-esterification reaction, and the second is an alkaline catalytic transesterification reaction, followed by vacuum distillation to generate biodiesel. 
$10^{\mathrm{TH}}$ INTERNATIONAL CONFERENCE ON SUSTAINABLE ENERGY AND ENVIRONMENTAL Protection (June $27^{\mathrm{TH}}-30^{\mathrm{TH}}, 2017$, Bled, Slovenia), WASte ENERGy AND

MANAGEMENT

H. Wang, Jianling Xu \& L. Sheng: Study on the Comprehensive Utilization of City

Kitchen Waste as a Resource in China

\section{Acknowledgements}

This project was supported by the Project of Changchun city technology bureau (No.16SS06).

\section{References}

[1] Z. K. Lee, P. C. Li, I. C. Chen, Y. M. Tien, Y. J. Huang, C. P. Chuang, et al., Thermophilic bio-energy process study on hydrogen fermentation with vegetable kitchen waste. International Journal of Hydrogen Energy, vol. 35, pp. 13458-13466, Dec. 2010.

[2] H. X. Wang, J. L. Xu, H. X. Yu, X. J. Liu, W. Yin, Y. Y. Liu, et al., Study of the application and methods for the comprehensive treatment of municipal solid waste in northeastern China. Renewable and Sustainable Energy Reviews, vol. 52, pp. 1881-1889, Dec. 2015.

[3] S. J. Bi, X. J. Hong, X. L. Han, Y. M. Gao, L. Yan, W. D. Wang, et al., Status and development of resource processing technologies of food waste. China Biogas, vol. 34, pp. 58-61, Feb. 2016.

[4] X. Y. Huang, J. T. Zhang, F. Wang, W. Z. He, and G. M. Li, Research progress in resource utilization of kitchen waste and its process pollution control. Chemical Industry and Engineering Progress, vol.35, pp. 2945-2951, Sept. 2016.

[5] P. Xu, and X. Z. Mu, Application and development of kitchen waste in energy production. Modern Chemical Industry, vol. 36, pp. 12-16, May. 2016.

[6] Y. P. Su, X. J. You, X. C. Zhan, R. Q. Lin, and L. H. Chen, Analysis of the main components of restaurant and kitchen garbage of Fuzhou city. Journal of Fujian Normal University (Natural Science Edition), vol. 30, pp. 58-64, Jan. 2014.

[7] R. P. Li, S. X. Wu, Z. G. Song, and Q. H. Tian, The impact of restaurant's type on their kitchen waste production. Environment Engineering, vol. 34, pp. 762-764, Aug. 2016.

[8] H. Zhang, Y. X. Chen, and Y. J. Chu, Analysis on food waste recycling and recovery in Suzhou city based on material flow analysis. Ecological Economy, vol. 31, pp. 126-132, Jun. 2015.

[9] H. S. Hafid, N. A. Rahman, U. K. M. Shah, and A. S. Baharudin, Enhanced fermentable sugar production from kitchen waste using various pretreatments. Journal of Environmental Management, vol. 156, pp. 290-298, Jun. 2015.

[10] X. T. Xie, Q. Sun, P. D. Zhang, and J. Y. Zhou, Life cycle assessment of municipal solid waste treatment: a review of impact comparative. Environmental Pollution and Control, vol. 37, pp. 106-110, Apr. 2015.

[11] Y. H. Wang, S. L. Li, I. C. Chen, I. C. Tseng, and S. S. Cheng, A study of the process control and hydrolytic characteristics in a thermophilic hydrogen fermentor fed with starch-rich kitchen waste by using molecular-biological methods and amylase assay. International Journal of Hydrogen Energy, vol. 35, pp. 13004-13012, Apr. 2010.

[12] H. Zou, W. Y. Zhang, L. Jiang, J. J. Yao, J. Liang, and Q. H. Wang, Bt biopesticide produced by semi-solid state fermentation from kitchen waste and its stability. Transactions of the Chinese Society of Agricultural Engineering (Transactions of the CSAE), vol. 32, pp. 268-273, Mar. 2016.

[13] J. Q. Ye, D. Li, Y. M. Sun, G. H. Wang, Z. H. Yuan, F. Zhen, et al., Improved biogas production from rice straw by co-digestion with kitchen waste and pig manure. Waste Management, vol. 33, pp. 2653-2658, May. 2013.

[14] Z. J. Pei, J. Liu, S. Wang, Y. B. Gao, and D. L. Zhang, Anaerobic digestion efficiency of mixed food wastes and cattle manure. China Biogas, vol. 32, pp. 3-7, Aug.2014. 
$10^{\text {TH }}$ INTERNATIONAL CONFERENCE ON SUSTAINABLE ENERGy AND ENVIRONMENTAL Protection (June $27^{\mathrm{TH}}-30^{\mathrm{TH}}, 2017$, Bled, SLOVENIA), WASTE ENERGY AND MANAGEMENT

H. Wang, Jianling Xu \& L. Sheng: Study on the Comprehensive Utilization of City Kitchen Waste as a Resource in China

[15] L. Wang, F. Shen, H. R. Yuan, D. X. Zou, Y. P. Liu, B. N. Zhu, et al., Anaerobic codigestion of kitchen waste and fruit/vegetable waste: Lab-scale and pilot-scale studies. Waste Management, vol. 34, pp. 2627-2633, Sep. 2014.

[16] Y. Y. Zheng, H. Lin, H. X. Luo, Y. F. Yu, and C. Q. Liu, Changes of substrate indices during methanogenesis from residue of fermentative hydrogen production using combined sludge and food waste. Chinese Journal of Environmental Engineering, vol. 9, pp. 425-430, Jan. 2015.

[17] J. Cai, W. W. Zhang, J. M. Yun, and J. Z. Wu, Optimization of microbial fermentation process to produce protein feed from kitchen waste. China Brewing, vol. 34, pp. 114-119, Feb. 2015. 
$10^{\mathrm{TH}}$ INTERNATIONAL CONFERENCE ON Sustainable ENERgy AND ENVIRONMENTAL PRotection (June $27^{\mathrm{TH}}-30^{\mathrm{TH}}$, 2017, Bled, Slovenia), WASTE ENERGY AND MANAGEMENT

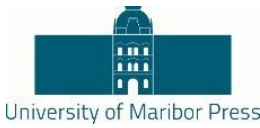

\title{
Heat Pipe Based Heat Exchanger for Clean Yerba Mate Drying Process
}

\author{
Hussam Jouhara, THEOdORA NANNOU, BERTRAND DELPECH, SUlaiman \\ Almahmoud, AMISHA CHAUHAN, MARK BOOCOCK, LUIZ WrOBEL, IGNACIO CARRAU \\ $\&$ FEDERICO CARRAU
}

\begin{abstract}
One major challenge that the Mate tea industry is currently facing is the high levels of Polycyclic Aromatic Hydrocarbons (PAHs) in the final product, due to the processing methods used. High concentrations of PAH in products is associated with an increased risk of various types of cancers. An optimum solution for the industry would be one that facilitates the continued use of biomass as the fuel source but that ensures the production of clean, hot air for drying that is guaranteed to be free of the cross contamination of the products of the combustion process. Heat pipe heat exchangers have the ability to guarantee zero cross contamination between the primary and secondary gases and hence offer a potential solution for the mate tea industry. The paper describes an innovative system that produces clean hot air to dry mate tea using different types of waste fuels, mainly agricultural wastes, transformed into clean fuel with high calorific value.
\end{abstract}

Keywords: $\bullet$ herbal leaves drying $\bullet$ heat pipe based heat exchanger $\bullet$ Yerba Mate $\bullet$ clean exhaust gas heat recovery $\bullet$

CoRResPONDENCE AdDREss: Hussam Jouhara, Ph.D., Reader/Associate Professor, Brunel University London, Institute of Energy Future, RCUK Centre for Sustainable Energy Use in Food Chains (CSEF), College of Engineering, Design and Physical Sciences, Brunel University London, UB8 3PH, UK, email: hussam.jouhara@ brunel.ac.uk. Theodora Nannou, Ph.D researcher, Brunel University London, Institute of Energy Future, RCUK Centre for Sustainable Energy Use in Food Chains (CSEF), College of Engineering, Design and Physical Sciences, Brunel University London, UB8 3PH, UK, e-mail:theodora.nannou@ brunel.ac.uk. Bertrand Delpech, Ph.D researcher, Brunel University London, Institute of Energy Future, RCUK Centre for Sustainable Energy Use in Food Chains (CSEF), College of Engineering, Design and Physical Sciences, Brunel University London, UB8 3PH, UK, e-mail: bertrand.delpech@brunel.ac.uk. Sulaiman Almahmoud, Ph.D researcher, Brunel University London, Institute of Energy Future, RCUK Centre for Sustainable Energy Use in Food Chains (CSEF), College of Engineering, Design and Physical Sciences, Brunel University London, UB8 3PH, UK, e-mail: sulaiman.almahmoud@brunel.ac.uk. Amisha Chauhan, Ph.D researcher, Brunel University London, Institute of Energy Future, RCUK Centre for Sustainable Energy Use in Food Chains (CSEF), College of Engineering, Design and Physical Sciences, Brunel University London, UB8 3PH, UK, e-mail: amisha.chauhan@ brunel.ac.uk. Mark Boocock, CEO, Econotherm(UK)Ltd, an associate company of Spirax SarcoEngineeringplc,F4,Waterton Rd, Bridgend, CF313YY, UK, e-mail: mark.boocock@econotherm.eu. Luiz Wrobel, Ph.D., Professor, Brunel University London, Mechanical Engineering, School of Engineering and Design, UB8 3PH, UK, luiz.wrobel@brunel.ac.uk. Ignacio Carrau, CEO, Sao Mateus do Sul, Rua Theodoro Rutckewiski 439, Cep 83.900.000, Brazil, Federico Carrau, CEO, Sao Mateus do Sul, Rua Theodoro Rutckewiski 439, Cep 83.900.000, Brazil.

https://doi.org/10.18690/978-961-286-063-9.2

ISBN 978-961-286-063-9

(C) 2017 University of Maribor Press

Available at: http://press.um.si. 
$10^{\text {TH }}$ INTERNATIONAL CONFERENCE ON SUSTAINABLE ENERGY AND ENVIRONMENTAL Protection (June $27^{\mathrm{TH}}-30^{\mathrm{TH}}, 2017$, BLED, SLOVENiA), WASTE ENERGY AND MANAGEMENT

H. Jouhara, T. Nannou, B. Delpech, S. Almahmoud, A. Chauhan, M. Boocock, L. Wrobel, I. Carrau \& F. Carrau: Heat Pipe Based Heat Exchanger for Clean Yerba Mate Drying Process

Ilex paraguariensis extracts, also known as mate or yerba, is a herbal beverage rich in caffeine, traditionally consumed in central and southern regions of South America, especially in Brazil and Argentina [1]. The composition of mate includes a variety of polyphenols, xanthines, caffeoyl derivatives, saponins and minerals [2], which gives mate antioxidant [3]-[5], inflammatory [6], antiobesity [7], [8], digestive [9], antidiabetic [10], diuretic [11] and antifungal [12] properties [13]. However, some studies indicate that people who drink large amounts of yerba mate over prolonged periods may be at increased risk of some types of cancer, such as prostate, colorectal, mouth, oesophageal, laryngeal, kidney, bladder, and lung and pancreatic cancers [13]-[21]. One possible explanation is that mate contains polycyclic aromatic hydrocarbons (PAHs), which are known to be carcinogenic. PAHs are a group of substances which comprise fused aromatic rings, formed through incomplete combustion or pyrolysis of any kind of organic matter, such as oil or firewood [22], [23]. Foods processing methods, particular smoking or heat treatments at high temperatures, such as drying, roasting, grilling, frying, etc., create PAHs particulates, which accumulate in the lipid tissue of organic products, such as meat, herbs etc.. On consumption, PAHs can be actively engaged in metabolic activation in human cells and tissues and develop mutations of the genetic material DNA [24]. During the manufacture of yerba mate tea, freshly harvested leaves go through a severe heat treatment. First, they are subjected to direct exposure to flame, followed by a final drying step, where the raw material comes into direct contact with hot air and combustion gases from the burning of biomass, such as wood, wood chips, leaves etc. [22], [25], [26].

\section{$2 \quad$ Processing}

The conditions of processing yerba mate tea are widely varied, depending on the producer and the final objective for the desired style and flavour of tea [25]. Nevertheless, the processing of mate consists of seven steps: harvesting, roasting, drying, milling, aging, grinding and packing [27]. During the first step, harvesting, the raw matter is collected from the cultivation and then carried to the processing plant. The next step is the roasting or 'sapecado', by which the leaves are passing through the flame of a furnace in order to inactivate the oxidising enzymes of the leaves and to preserve their colour, flavour and odour. During this stage the leaves are directly exposed to temperatures between 250 to $550^{\circ} \mathrm{C}$ for a time period of 2 to 4 minutes, and their moisture content is reduced by $25 \%$ approximately [27]. Upon entering the drying system, the leaves receive direct heat by the means of hot air $\left(100-120^{\circ} \mathrm{C}\right)$, until a 2 to $4 \%$ moisture is reached. This prevents the development of fungus. Then, the leaves are ready for milling or 'canheado', a process which crushes and sieves the leaves before being packed for their maturation. Aging is an absolutely necessary process for the yerba mate tea in order to acquire the adequate flavour, aroma and colour. During a period of 6 to 12 months the crushed leaves are placed into bags and stored under natural conditions of temperature and humidity, to 
$10^{\mathrm{TH}}$ INTERNATIONAL CONFERENCE ON SUSTAINABLE ENERGY AND ENVIRONMENTAL Protection (June $27^{\mathrm{TH}}-30^{\mathrm{TH}}, 2017$, Bled, Slovenia), WASte ENERGy AND

MANAGEMENT

H. Jouhara, T. Nannou, B. Delpech, S. Almahmoud, A. Chauhan, M. Boocock, L. Wrobel, I. Carrau \& F. Carrau: Heat Pipe Based Heat Exchanger for Clean Yerba Mate Drying Process

allow the proper process of antioxidation and flavour [28]. The final steps of yerba mate processing are: grinding and packing. The leaves are grounded into different sizes and mixed to produce different blends, before they are packed and distributed worldwide. [27], [28]

The current drying and roasting processes have been suggested as a carcinogenic source as it is believed to cause the high levels of PAHs. The formation of PAHs in a product depends on a number of parameters such as time, heat source, design of the drying device, type of fuel and distance from the heat source [29]-[31]. The most common drying processing techniques are: freeze-drying, hot air drying, oven-drying, spray-drying, vacuum-drying and microwave drying.

\subsection{Exhaust Gas Heat Recovery}

The drying process is the most crucial and energy demanding operation of most industrial processes, accounting of 10 to $25 \%$ of the total energy consumption of the industry [32]. It is claimed that more than 200 dryer types exist, however they can all be described by the same drying features: air velocity, relative humidity, temperature and product retention time [33].

A solution to the problem is to dry the tea leaves with hot clean air rather than smoke exhausted, but this poses the issue of energy cost and increase of $\mathrm{CO}_{2}$ emissions. There is ample evidence within the industry that confirms that clean air drying offers a safer product and that the flavour is not affected since the wood smoke drying process did not previously contribute to the flavour of the product. Using conventional equipment, the production of clean, dry air will require electrical air heaters that have both high capital cost as well as large energy consumption.

Lots of research has been dedicated to improve the energy efficiency of drying processes and the final product's quality. Heat recovery of the exhausted heat from the dryer is one of the many suggested energy-saving solutions, which can reduce the running cost of the production line significantly.

In this paper an innovative solution of a heat pipe based heat exchanger for the recovery of heat from exhaust gases and its further use for the drying process of tea leaves is presented. Although, there is no literature evidence of the use of heat pipe based heat exchangers in the drying process of foodstuff, the systems have been successfully and widely applied in other industries, where clean and contaminant free air is required. One of the first published papers presenting the potentials of waste heat recovery using heat pipe based heat exchangers was prepared by Noie-Baghban and Majideian and it was a study for surgery rooms in hospitals [34]. In their study the characteristic design and heat transfer limitations of single heat pipes for three types of wick and three working fluids were investigated initially through simulations and confirmed by the design of an 
H. Jouhara, T. Nannou, B. Delpech, S. Almahmoud, A. Chauhan, M. Boocock, L. Wrobel, I. Carrau \& F. Carrau: Heat Pipe Based Heat Exchanger for Clean Yerba Mate Drying Process

air-to-air heat pipe heat exchanger operating at low temperature conditions. Their research was a major stepping stone for other researchers focusing on energy recovery with heat pipe based heat exchangers.

A few years later, Yang et al. [35] designed a heat pipe based heat exchanger to provide heating of automobiles using recovered heat from the exhaust gases. Their system consisted of 50 heat pipes with two passages separated by a separation plate and connected through the heat pipes. Their results concluded that they system is performing as expected, and could be potentially used in automobiles, without influencing the engine efficiency.

Tian et al. [36] recently presented their research regarding a new type of waste heat recovery gravity heat pipe exchanger. Their system is an air-to-air heat exchanger, which recovers heat from the exhaust gas dispersed by the dyeing and printing processes, to heat up fresh intake of ambient air and reintroduce it to the process. Their design managed to save up to $15 \%$ of fuel.

\subsection{Type of Fuels}

For the drying of herbal leaves conventional thermal energy sources, such as natural gas, furnace oil and coal have been extensively used [37]. However, the volatile of price and various environmental and health factors associated with the use of fossil fuels has led the industry towards more sustainable energy sources, like biomass. The term 'biomass' refers to energy crops - specific plants grown to be used as fuels - and agricultural or industrial waste, such as forestry residues, sawdust, pulp, municipal waste etc. However, the use of biomass as a fuel for drying processing generates PAHs from the incomplete combustion of the organic matter.

\section{$3 \quad$ System design}

A heat pipe based heat exchanger system has been developed for the drying process of yerba/mate tea industry. The system provides an optimum solution for the yerba/mate tea industry, as it facilitates the continuous use of biomass as the fuel source but ensures the production of clean, hot air for drying that is guaranteed to be free of the harmful byproducts from biomass combustion. The system is installed as a lab scaled prototype unit in the process factory of Ervateira Sao Mateus Ltda., in Sao Mateus Do Sul, Parana, Brazil. The layout of the process factory of Ervateira Sao Mateus Ltda in Brazil and the position of the equipment is shown in Figure 1. 
$10^{\mathrm{TH}}$ INTERNATIONAL CONFERENCE ON SUSTAINABLE ENERGY AND ENVIRONMENTAL Protection (June $27^{\mathrm{TH}}-30^{\mathrm{TH}}, 2017$, Bled, Slovenia), WASte ENERGy AND

MANAGEMENT

H. Jouhara, T. Nannou, B. Delpech, S. Almahmoud, A. Chauhan, M. Boocock, L. Wrobel, I. Carrau \& F. Carrau: Heat Pipe Based Heat Exchanger for Clean Yerba Mate Drying Process

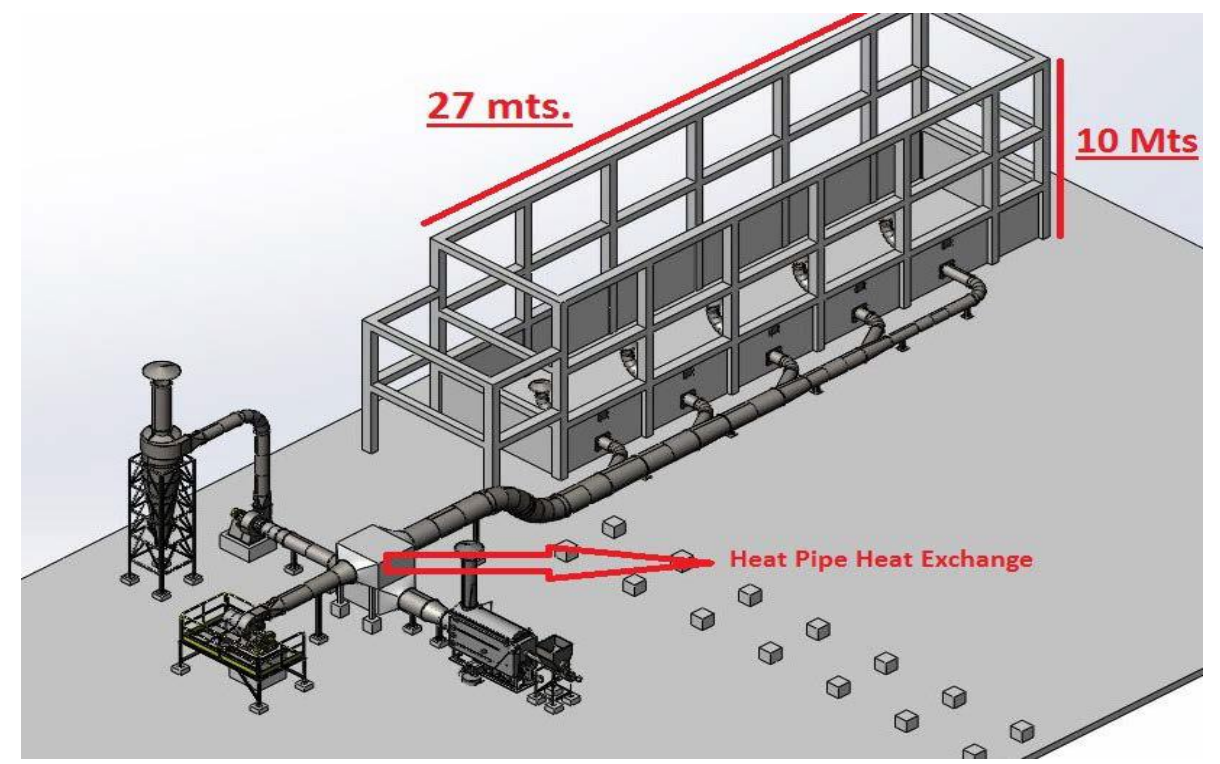

Figure 1: Ervateira Sao Mateus Ltda process factory layout

Figure 2 shows the construction design of the proposed heat pipe based heat exchanger. The device is designed in such way to transfer heat between the hot exhaust gases and a cool fresh air stream, without their direct contact, as the two streams are separated by a solid wall separation plate.

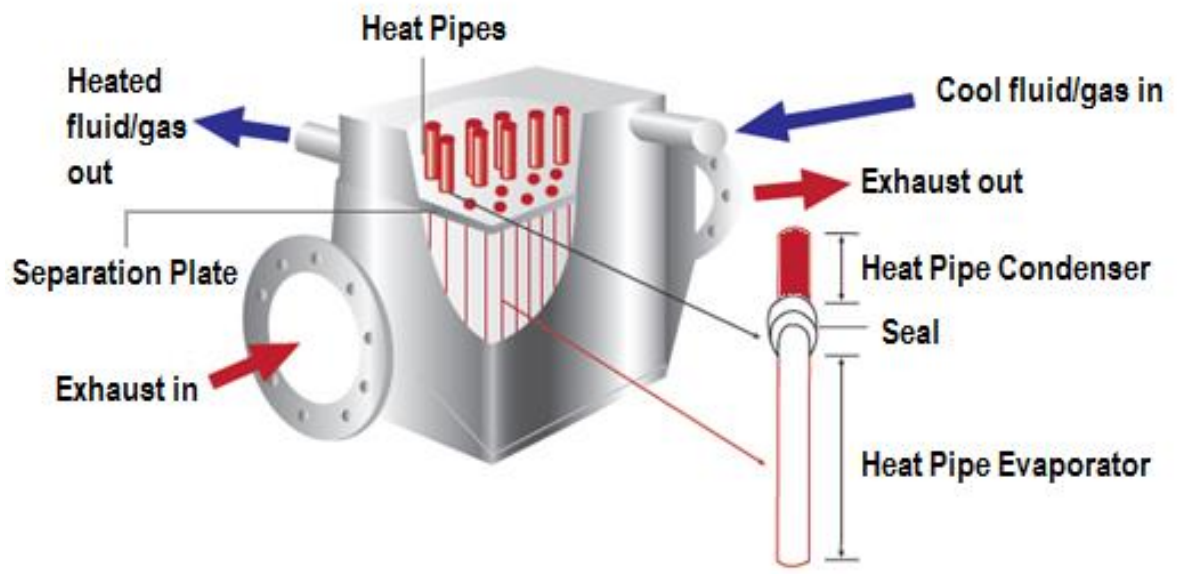

Figure 2: Heat pipe based heat exchanger construction 
$10^{\mathrm{TH}}$ INTERNATIONAL CONFERENCE ON SUSTAINABLE ENERGY AND ENVIRONMENTAL Protection (June $27^{\mathrm{TH}}-30^{\mathrm{TH}}, 2017$, Bled, SLOVEnia), WASte ENERGy AND MANAGEMENT

H. Jouhara, T. Nannou, B. Delpech, S. Almahmoud, A. Chauhan, M. Boocock, L. Wrobel, I. Carrau \& F. Carrau: Heat Pipe Based Heat Exchanger for Clean Yerba Mate Drying Process

Instead of conventional tube rows, the device consists of rows of heat pipes, which allow the indirect heat transfer between the two streams.

A heat pipe is basically a vacuum sealed tube, filled with a small quantity of working fluid. The fluid used depends upon the required working temperature range of the heat pipe. Heat pipes are described by instantaneous response to heat input, isothermal operation, low maintenance requirements and reliable operation.

The heat pipe based heat exchanger encloses 100 heat pipes. The number of heat pipes as tube rows of the heat exchanger was decided based on the maximisation of the operational performance of the system. Greater number of tube rows could recover more heat, but pressure drop and fouling issues would have greater affect in the performance of the pipes after a period of time. The full scale unit of the heat pipe based heat exchanger is shown in Napaka! Vira sklicevanja ni bilo mogoče najti..

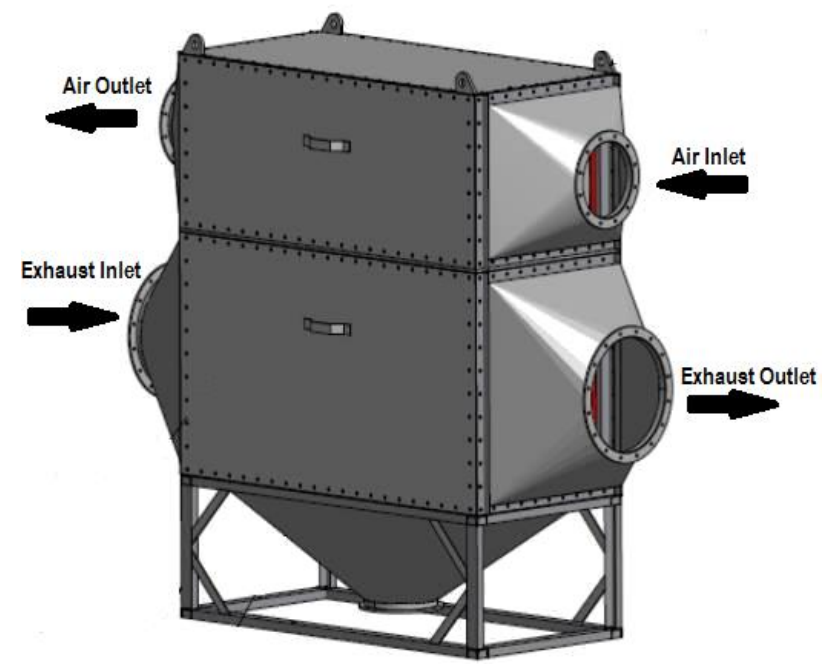

The exhaust gases are passing through the bottom half of the structure, while the upper part is introducing fresh air into the heat exchanger. As the hot exhaust gas stream passes through the bottom part of the heat pipes, the heat supplied to the evaporators of the heat pipes vaporises their enclosed working fluids. As the vapour travels upwards to the condenser, the heat pipe disperse the latent heat of the vapour by liquefying the working fluid, which flows back down to the evaporator, forced by gravitational forces and repeats its cycle. The fresh air stream increases its temperature by the heat dispersed from the heat pipes, providing a $100 \%$ clean hot air, free of any harmful substances, ready to be used for the drying process of tea leaves. 
$10^{\mathrm{TH}}$ INTERNATIONAL CONFERENCE ON SUSTAINABLE ENERGY AND ENVIRONMENTAL Protection (June $27^{\mathrm{TH}}-30^{\mathrm{TH}}, 2017$, Bled, Slovenia), WASte ENERGy AND

MANAGEMENT

H. Jouhara, T. Nannou, B. Delpech, S. Almahmoud, A. Chauhan, M. Boocock, L. Wrobel, I. Carrau \& F. Carrau: Heat Pipe Based Heat Exchanger for Clean Yerba Mate Drying Process

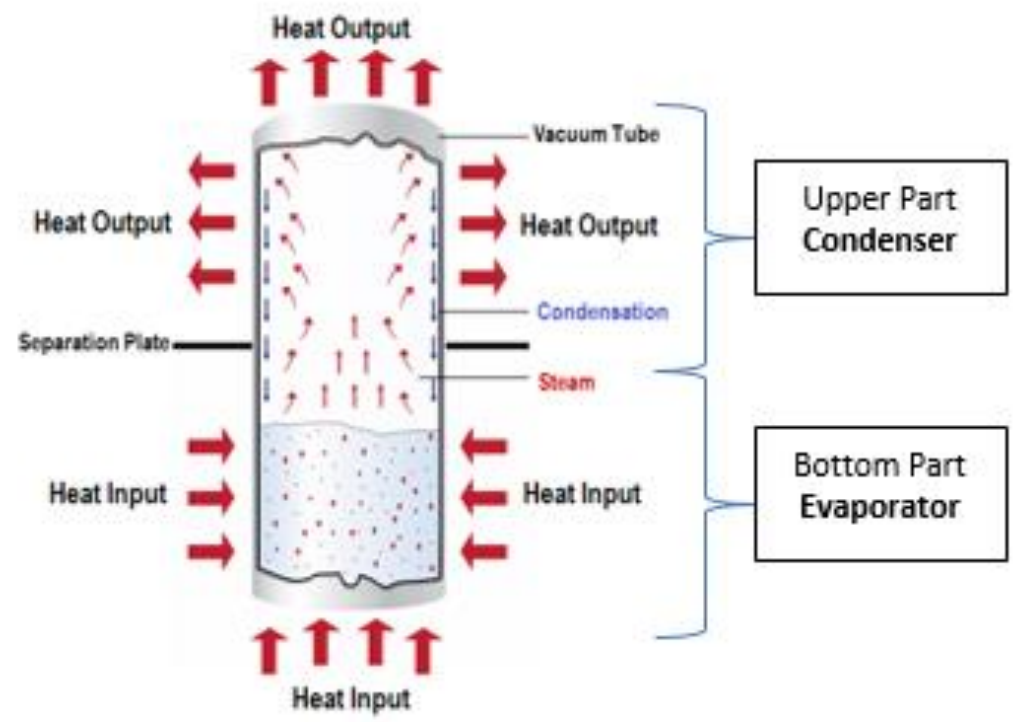

Figure 3: Heat pipe operation

\section{4}

\section{Results}

The experiments showed that the heat pipe based heat exchanger was capable of warming up the $100 \%$ fresh air intake from its ambient temperature $\left(30^{\circ} \mathrm{C}\right)$ to around $150^{\circ} \mathrm{C}$, without the use of any external source. The temperature results for the steady state operation of the exchanger are shown in Figure 4.

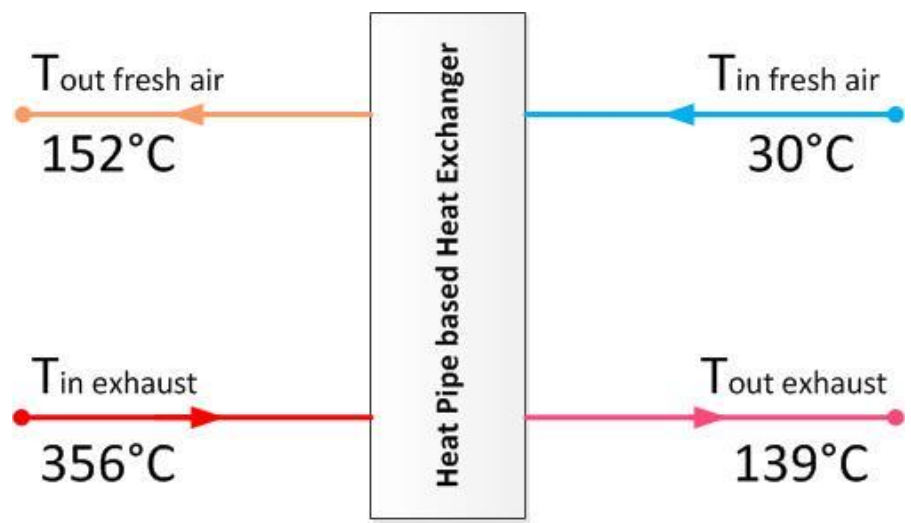

Figure 4: Temperature results achieved from the installation of the heat pipe based heat exchanger 
$10^{\mathrm{TH}}$ INTERNATIONAL CONFERENCE ON SUSTAINABLE ENERGY AND ENVIRONMENTAL Protection (June $27^{\mathrm{TH}}-30^{\mathrm{TH}}, 2017$, Bled, Slovenia), WASte ENERGy AND MANAGEMENT

H. Jouhara, T. Nannou, B. Delpech, S. Almahmoud, A. Chauhan, M. Boocock, L. Wrobel, I. Carrau \& F. Carrau: Heat Pipe Based Heat Exchanger for Clean Yerba Mate Drying Process

From the above data the temperature transfer efficiency of the system can be calculated by the following formula:

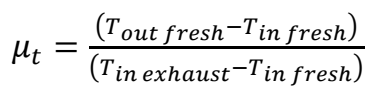

Where:

$\mu_{t}$ is the temperature transfer efficiency

$T_{\text {in fresh }}$ is the temperature of the fresh outside make-up air before the heat exchanger $\left({ }^{\circ} \mathrm{C}\right)$

$T_{\text {out fresh }}$ is the temperature of the fresh outside make-up air after the heat exchanger $\left({ }^{\circ} \mathrm{C}\right)$

$T_{\text {in exhaust }}$ is the temperature of the exhaust gas air stream before enters the heat exchanger $\left({ }^{\circ} \mathrm{C}\right)$

Based on equation (1) the temperature transfer efficiency of the heat pipe based heat exchanger tested on the process factory of Ervateira Sao Mateus Ltda found to be 0.37.

\section{$5 \quad$ Conclusions}

An optimum solution for the yerba/mate tea industry would be one that facilitates the continued use of biomass as the fuel source but that ensures the production of clean, hot air for drying that is guaranteed to be free of the harmful by-products from biomass combustion. There is currently no conventionally available equipment capable of achieving this and hence an innovative solution is required. Heat pipe heat exchangers have the ability to guarantee zero cross contamination between the primary and secondary gases and hence offer a potential solution but have yet to be utilised in this application.

The paper presents the thermal data achieved by an innovative design of heat exchanger, based on heat pipe technology, to recover heat from the exhaust gases of an herbal leaves process factory. As it was presented formerly in the paper, the drying process of the yerba/mate tea leaves require their direct exposure to a hot air stream of a temperature between 100 to $120^{\circ} \mathrm{C}$. Based on the experimental data obtained the heat pipe based heat exchanger managed to provide a $100 \%$ fresh air at a temperature of $150^{\circ} \mathrm{C}$, with no use of external heat sources.

The achieved experimental results are very promising, which may lead to a breakthrough in the yerba/mate tea industry, by eliminating any health risk associated with the production of the specific tea. However, more in depth research should be conducted, analysing samples from the dried yerba/mate leaves to ensure that the final product is free of any harmful by-products, as it is assumed in this stage. 
$10^{\mathrm{TH}}$ INTERNATIONAL CONFERENCE ON SUSTAINABLE ENERGY AND ENVIRONMENTAL Protection (June $27^{\mathrm{TH}}-30^{\mathrm{TH}}, 2017$, Bled, SLOVEnia), WASTE ENERGY AND

MANAGEMENT

H. Jouhara, T. Nannou, B. Delpech, S. Almahmoud, A. Chauhan, M. Boocock, L. Wrobel, I. Carrau \& F. Carrau: Heat Pipe Based Heat Exchanger for Clean Yerba Mate

Drying Process

\section{Acknowledgements}

The project is funded by Innovate UK and operates in partnership with Econotherm UK Ltd, Brunel University London, the Brazilian National Service for Industrial Training (SENAI) and Ervateira Sao Mateus Ltda.

\section{References}

[1] M. C. A. Marcelo, C. A. Martins, D. Pozebon, V. L. Dressler, and M. F. Ferrão, "Classification of yerba mate (Ilex paraguariensis) according to the country of origin based on element concentrations," Microchem. J., vol. 117, pp. 164-171, Nov. 2014.

[2] K. P. Burris, F. M. Harte, P. M. Davidson, C. N. Stewart, and S. Zivanovic, "Composition and bioactive properties of Yerba Mate (Ilex paraguariensis A. St.-Hil.): A review," Chil. J. Agric. Res., vol. 72, no. 2, pp. 268-274, 2012.

[3] M. Bixby, L. Spieler, T. Menini, and A. Gugliucci, "Ilex paraguariensis extracts are potent inhibitors of nitrosative stress: A comparative study with green tea and wines using a protein nitration model and mammalian cell cytotoxicity," Life Sci., vol. 77, no. 3, pp. 345358, Jun. 2005.

[4] B. C. B. Boaventura, P. F. Di Pietro, A. Stefanuto, G. A. Klein, E. C. de Morais, F. de Andrade, E. Wazlawik, and E. L. da Silva, "Association of mate tea (Ilex paraguariensis) intake and dietary intervention and effects on oxidative stress biomarkers of dyslipidemic subjects," Nutrition, vol. 28, no. 6, pp. 657-664, Jun. 2012.

[5] A. Gugliucci and A. J. Stahl, "Low density lipoprotein oxidation is inhibited by extracts of Ilex paraguariensis.," Biochem. Mol. Biol. Int., vol. 35, no. 1, pp. 47-56, Jan. 1995.

[6] K. P. Burris, P. M. Davidson, C. N. Stewart, and F. M. Harte, "Antimicrobial activity of Yerba Mate (Ilex paraguariensis) aqueous extracts against Escherichia coli O157:H7 and Staphylococcus aureus.," J. Food Sci., vol. 76, no. 6, pp. M456-62, Aug. 2011.

[7] D. P. Arçari, W. Bartchewsky, T. W. dos Santos, K. A. Oliveira, A. Funck, J. Pedrazzoli, M. F. F. de Souza, M. J. Saad, D. H. M. Bastos, A. Gambero, P. de O. Carvalho, and M. L. Ribeiro, "Antiobesity Effects of yerba maté Extract (Ilex paraguariensis) in High-fat Dietinduced Obese Mice," Obesity, vol. 17, no. 12, pp. 2127-2133, Dec. 2009.

[8] T. Andersen and J. Fogh, "Weight loss and delayed gastric emptying following a South American herbal preparation in overweight patients.," J. Hum. Nutr. Diet., vol. 14, no. 3, pp. 243-50, Jun. 2001.

[9] S. Gorzalczany, R. Filip, M. R. Alonso, J. Miño, G. E. Ferraro, and C. Acevedo, "Choleretic effect and intestinal propulsion of 'mate' (Ilex paraguariensis) and its substitutes or adulterants.," J. Ethnopharmacol., vol. 75, no. 2-3, pp. 291-4, May 2001.

[10] N. Lunceford and A. Gugliucci, "Ilex paraguariensis extracts inhibit AGE formation more efficiently than green tea.," Fitoterapia, vol. 76, no. 5, pp. 419-27, Jul. 2005.

[11] M. Görgen, K. Turatti, A. R. Medeiros, A. Buffon, C. D. Bonan, J. J. F. Sarkis, and G. S. Pereira, "Aqueous extract of Ilex paraguariensis decreases nucleotide hydrolysis in rat blood serum,” J. Ethnopharmacol., vol. 97, no. 1, pp. 73-77, Feb. 2005.

[12] R. Filip, R. Davicino, and C. Anesini, "Antifungal activity of the aqueous extract of Ilex paraguariensis against Malassezia furfur.," Phytother. Res., vol. 24, no. 5, pp. 715-9, May 2010.

[13] N. Bracesco, A. G. Sanchez, V. Contreras, T. Menini, and A. Gugliucci, "Recent advances on Ilex paraguariensis research: Minireview," J. Ethnopharmacol., vol. 136, no. 3, pp. 378384, Jul. 2011. 
$10^{\text {TH }}$ INTERNATIONAL CONFERENCE ON SUSTAINABLE ENERGY AND ENVIRONMENTAL Protection (June $27^{\mathrm{TH}}-30^{\mathrm{TH}}, 2017$, Bled, Slovenia), WASTE ENERGy AND

MANAGEMENT

H. Jouhara, T. Nannou, B. Delpech, S. Almahmoud, A. Chauhan, M. Boocock, L. Wrobel, I. Carrau \& F. Carrau: Heat Pipe Based Heat Exchanger for Clean Yerba Mate Drying Process

[14] A. Vassallo, P. Correa, E. De Stéfani, M. Cendán, D. Zavala, V. Chen, J. Carzoglio, and H. Deneo-Pellegrini, "Esophageal cancer in Uruguay: a case-control study.," J. Natl. Cancer Inst., vol. 75, no. 6, pp. 1005-9, Dec. 1985.

[15] E. De Stefani, P. Correa, F. Oreggia, H. Deneo-Pellegrini, G. Fernandez, D. Zavala, J. Carzoglio, J. Leiva, E. Fontham, and S. Rivero, "Black tobacco, wine and mate in oropharyngeal cancer. A case-control study from Uruguay.," Rev. Epidemiol. Sante Publique, vol. 36, no. 6, pp. 389-94, 1988.

[16] J. Pintos, E. L. Franco, B. V Oliveira, L. P. Kowalski, M. P. Curado, and R. Dewar, "Maté, coffee, and tea consumption and risk of cancers of the upper aerodigestive tract in southern Brazil.," Epidemiology, vol. 5, no. 6, pp. 583-90, Nov. 1994.

[17] V. Sewram, E. De Stefani, P. Brennan, and P. Boffetta, "Maté consumption and the risk of squamous cell esophageal cancer in uruguay.," Cancer Epidemiol. Biomarkers Prev., vol. 12, no. 6, pp. 508-13, Jun. 2003.

[18] J. H. Lubin, E. De Stefani, C. C. Abnet, G. Acosta, P. Boffetta, C. Victora, B. I. Graubard, N. Munoz, H. Deneo-Pellegrini, S. Franceschi, X. Castellsague, A. L. Ronco, and S. M. Dawsey, "Mate Drinking and Esophageal Squamous Cell Carcinoma in South America: Pooled Results from Two Large Multicenter Case-Control Studies," Cancer Epidemiol. Biomarkers Prev., vol. 23, no. 1, pp. 107-116, Jan. 2014.

[19] I. Al-Dakkak and A. Ternouth, "Maté intake and risk of oral and pharyngeal cancers," Evid. Based. Dent., vol. 13, no. 1, pp. 18-19, Mar. 2012.

[20] A. L. Ronco, E. De Stefani, B. Mendoza, H. Deneo-Pellegrini, A. Vazquez, and E. Abbona, "Mate Intake and Risk of Breast Cancer in Uruguay: a Case-Control Study," Asian Pacific J. Cancer Prev., vol. 17, no. 3, pp. 1453-1461, Apr. 2016.

[21] I. Almog, F. Alawi, and J. M. Laudenbach, "Case report of yerba maté drinking and persistent oral lesions," Oral Surgery, Oral Med. Oral Pathol. Oral Radiol. Endodontology, vol. 102, no. 3, p. 334, Sep. 2006.

[22] A. E. Thea, D. Ferreira, L. A. Brumovsky, and M. E. Schmalko, "Polycyclic aromatic hydrocarbons (PAHs) in yerba maté (Ilex paraguariensis St. Hil) traditional infusions (mate and tereré)," Food Control, vol. 60, pp. 215-220, Feb. 2016.

[23] R. F. de Lima, R. G. Dionello, M. do C. R. Peralba, S. Barrionuevo, L. L. Radunz, and F. W. Reichert Júnior, "PAHs in corn grains submitted to drying with firewood," Food Chem., vol. 215, pp. 165-170, Jan. 2017.

[24] D. H. Phillips, "Polycyclic aromatic hydrocarbons in the diet.," Mutat. Res., vol. 443, no. 1-2, pp. 139-47, Jul. 1999.

[25] C. I. Heck and E. G. de Mejia, "Yerba Mate Tea (Ilex paraguariensis): a comprehensive review on chemistry, health implications, and technological considerations.," J. Food Sci., vol. 72, no. 9, pp. R138-51, Nov. 2007.

[26] M. E. Schmalko and S. M. Alzamora, "COLOR, CHLOROPHYLL, CAFFEINE, AND WATER CONTENT VARIATION DURING YERBA MATÉ PROCESSING," Dry. Technol., vol. 19, no. 3-4, pp. 599-610, Mar. 2001.

[27] S. Isolabella, L. Cogoi, P. López, C. Anesini, G. Ferraro, and R. Filip, "Study of the bioactive compounds variation during yerba mate (Ilex paraguariensis) processing," Food Chem., vol. 122, no. 3, pp. 695-699, Oct. 2010.

[28] E. S. MATEUS, "ERVATEIRA Sao Mateus." .

[29] W. Lijinsky, "The formation and occurrence of polynuclear aromatic hydrocarbons associated with food.," Mutat. Res., vol. 259, no. 3-4, pp. 251-61.

[30] B. Veyrand, A. Brosseaud, L. Sarcher, V. Varlet, F. Monteau, P. Marchand, F. Andre, and B. Le Bizec, "Innovative method for determination of 19 polycyclic aromatic hydrocarbons 
$10^{\mathrm{TH}}$ INTERNATIONAL CONFERENCE ON SUSTAINABLE ENERGY AND ENVIRONMENTAL 19 Protection (June $27^{\mathrm{TH}}-30^{\mathrm{TH}}, 2017$, Bled, SLOVEnia), WASTE ENERGY AND

MANAGEMENT

H. Jouhara, T. Nannou, B. Delpech, S. Almahmoud, A. Chauhan, M. Boocock, L. Wrobel, I. Carrau \& F. Carrau: Heat Pipe Based Heat Exchanger for Clean Yerba Mate Drying Process

in food and oil samples using gas chromatography coupled to tandem mass spectrometry based on an isotope dilution approach," J. Chromatogr. A, vol. 1149, no. 2, pp. 333-344, May 2007.

[31] V. Bansal and K.-H. Kim, "Review of PAH contamination in food products and their health hazards," Environ. Int., vol. 84, pp. 26-38, Nov. 2015.

[32] D. I. Onwude, N. Hashim, and G. Chen, "Recent advances of novel thermal combined hot air drying of agricultural crops," Trends Food Sci. Technol., vol. 57, pp. 132-145, Nov. 2016.

[33] D. I. Onwude, N. Hashim, R. B. Janius, N. M. Nawi, and K. Abdan, "Modeling the ThinLayer Drying of Fruits and Vegetables: A Review," Compr. Rev. Food Sci. Food Saf., vol. 15, no. 3, pp. 599-618, May 2016.

[34] S. H. Noie-Baghban and G. R. Majideian, "Waste heat recovery using heat pipe heat exchanger (HPHE) for surgery rooms in hospitals," Appl. Therm. Eng., vol. 20, no. 14, pp. 1271-1282, Oct. 2000.

[35] F. Yang, X. Yuan, and G. Lin, "Waste heat recovery using heat pipe heat exchanger for heating automobile using exhaust gas," Appl. Therm. Eng., vol. 23, no. 3, pp. 367-372, Feb. 2003.

[36] E. Tian, Y.-L. He, and W.-Q. Tao, "Research on a new type waste heat recovery gravity heat pipe exchanger," Appl. Energy, vol. 188, pp. 586-594, Feb. 2017.

[37] P. P. Dutta and D. C. Baruah, "Gasification of tea (Camellia sinensis (L.) O. Kuntze) shrubs for black tea manufacturing process heat generation in Assam, India," Biomass and Bioenergy, vol. 66, pp. 27-38, Jul. 2014. 
\begin{tabular}{l|l}
20 & $10^{\text {TH }}$ INTERNATIONAL CONFERENCE ON SUSTAINABLE ENERGY AND ENVIRONMENTAL
\end{tabular}

Protection (June $27^{\mathrm{TH}}-30^{\mathrm{TH}}, 2017$, Bled, SLOVENiA), WAste ENERGY AND

MANAGEMENT 
$10^{\mathrm{TH}}$ InTERnational CONFEREnCE ON Sustainable ENERgy AND

ENVIRONMENTAL PRotection (June $27^{\mathrm{TH}}-30^{\mathrm{TH}}$, 2017, Bled, Slovenia), WASTE ENERGY AND MANAGEMENT

J. Krope, A.Ghani Olabi, D. Goričanec \& S. Božičnik

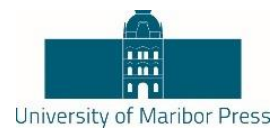

\title{
Production of Diesel-Like Oil as Potential Fuel from Microwave-Assisted Pyrolysis of Waste Shipping Oil
}

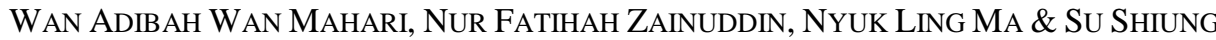 \\ LAM
}

\begin{abstract}
Waste shipping oil derived from ship engine operation was tested for its potential to be converted into a fuel product via an innovative microwave-assisted pyrolysis approach. Higher carbon to waste ratio was found to have beneficial effects in promoting pyrolysis cracking to produce a higher yield of pyrolysis oil, recording a yield of up to $66 \mathrm{wt} \%$. The pyrolysis oil showed a high $\mathrm{H} / \mathrm{C}$ atomic ratio and high calorific value (46 $\mathrm{MJ} / \mathrm{kg}$ ), thus, shows potential to be upgraded to diesel fuel. The oil product was also detected to have lower contents of oxygen $(0.1 \mathrm{wt} \%)$ and sulphur (0.02 wt $\%)$, showing promising features as a 'cleaner' fuel source with potentially reduced formation of tar and low emission of SOx during the use of the oil as fuel in combustion process. The results indicate that microwave-assisted pyrolysis shows potential to transform waste shipping oil into an alternative fuel.
\end{abstract}

Keywords: • pyrolysis $\bullet$ microwave $\bullet$ waste $\bullet$ ship $\bullet$ diesel $\bullet$

Correspondence Address: Wan Adibah Wan Mahari, Ph.D, Pyrolysis Technology Research Group, Eastern Corridor Renewable Energy Group (ECRE), School of Ocean Engineering, Universiti Malaysia Terengganu, 21030 Kuala Nerus, Terengganu, Malaysia, e-mail: adibah.mahari@gmail.com. Nur Fatihah Zainuddin, MSc., Pyrolysis Technology Research Group, Eastern Corridor Renewable Energy Group (ECRE), School of Ocean Engineering, Universiti Malaysia Terengganu, 21030 Kuala Nerus, Terengganu, Malaysia, e-mail: nurfatihah0406@gmail.com. Nyuk Ling Ma, Ph.D, School of Fundamental Sciences, Universiti Malaysia Terengganu, 21030 Kuala Nerus, Terengganu, Malaysia, email: nyukling@umt.edu.my, Su Shiung Lam, Ph.D, Pyrolysis Technology Research Group, Eastern Corridor Renewable Energy Group (ECRE), School of Ocean Engineering, Universiti Malaysia Terengganu, 21030 Kuala Nerus, Terengganu, Malaysia, e-mail: lam@umt.edu.my.

https://doi.org/10.18690/978-961-286-063-9.3

ISBN 978-961-286-063-9

(C) 2017 University of Maribor Press

Available at: http://press.um.si. 
$10^{\text {TH }}$ INTERNATIONAL CONFERENCE ON SUSTAINABLE ENERGy AND ENVIRONMENTAL Protection (June $27^{\mathrm{TH}}-30^{\mathrm{TH}}, 2017$, Bled, SLOVENIA), WASTE ENERGY AND

MANAGEMENT

W.Adibah Wan Mahari, N. Fatihah Zainuddin, N. Ling Ma \& S. Shiung Lam: Production of Diesel-Like Oil as Potential Fuel from Microwave-Assisted Pyrolysis of Waste Shipping Oil

Shipping industry such as maritime transportation and shipping operations often results in emission of sulphur oxides (SOx) to the atmosphere and waterways. This is due to the use of cheaper fuels with low quality and high sulphur content in shipping industry [1]. It has been reported that ships could release 50 times more sulphur to the atmosphere and contribute up to $40 \%$ of air pollution compared to land vehicles [2]. The sulphur may form sulphur oxides during combustion and lead to air pollution such as acid rain and smog.

Waste shipping oil, a mixture of used lubricating oil and seawater derived from ship engine operation, represent a waste that could bring devastating effect to the atmosphere and waterways if the oil is not properly handled. The shipping oil is used to maintain a good engine performance during shipping operation and avoids corrosion between the moving parts in the engine. However, the oil becomes unsuitable for further use after certain time of operation due to the deterioration of the oil quality, thus transforming into waste shipping oil. Waste shipping oil contains constituents such as polycyclic aromatic hydrocarbon $(\mathrm{PAH})$, metallic debris, sulphur, degraded additives and soot that are hazardous to the environment and human health [3]. It could also contain contaminants such as unburned fuel, water and chlorinated solvents derived from activities during the storage.

Recently, microwave pyrolysis technology has been developed to convert waste materials such as waste engine oil, waste cooking oil and waste lubricating oil into potential fuel source [4-8]. It has drawn considerable attention due to the promising findings from the unique heating characteristics of microwave pyrolysis. Microwave pyrolysis is a thermochemical conversion technique performed in an inert atmosphere at temperature range of 300 to $700{ }^{\circ} \mathrm{C}$ using microwave radiation as the heating source. Nevertheless, microwave radiation can only interact with polar materials to generate heat efficiently. The heat is generated from the rotation of permanent and induce dipoles during their alignment with the electric field [9]. The movement of the molecules from the rotation creates friction and consequently releases energy in the form of heat. Waste shipping oil is a non-polar material and poor in absorbing microwave radiation. Nevertheless, it consists of seawater (a polar material) that can assist in absorbing and converting microwave radiation into heat to pyrolyze the waste oil molecules during microwave heating. However, previous researchers have reported that microwave pyrolysis of waste shipping oil in the absence of microwave absorbent can only be heated up to $114{ }^{\circ} \mathrm{C}$ within 1 hour of reaction time [4]. This suggests that the tiny amount of water content in waste shipping oil was not able to generate heat to reach a high temperature in order for pyrolysis of waste oil to occur. Therefore, a solid material with good microwave absorbency is needed to generate sufficient heat to pyrolyze waste shipping oil during microwave pyrolysis. Carbonaceous materials such as activated carbon and graphite have been reported as a good microwave absorbent due to their ability to be heated rapidly in 
$10^{\mathrm{TH}}$ INTERNATIONAL CONFERENCE ON SUSTAINABLE ENERGY AND ENVIRONMENTAL Protection (June $27^{\mathrm{TH}}-30^{\mathrm{TH}}, 2017$, Bled, Slovenia), WASte ENERGy AND

MANAGEMENT

W.Adibah Wan Mahari, N. Fatihah Zainuddin, N. Ling Ma \& S. Shiung Lam: Production of Diesel-Like Oil as Potential Fuel from Microwave-Assisted Pyrolysis of Waste Shipping Oil

a microwave field. This ability is derived from their dielectric loss tangent, where activated carbon possess higher dielectric loss tangent ( 0.5 to 0.8 ) compared to water $(\sim 0.1)$, which is recognized as an excellent microwave absorbent $[9,10]$.

This study was perform to investigate the potential of using microwave pyrolysis coupled with a reaction bed of activated carbon to transform waste shiping oil into a potentially useful oil product (termed "pyrolysis oil"). The effect from the use of different amounts of activated carbon to form the reaction bed relative to the amount of waste shipping oil (termed "carbon to waste ratio") on the mass yield, energy recovery and characteristics of pyrolysis oil were examined and discussed.

\section{$2 \quad$ Materials and methods}

\subsection{Materials}

Waste shipping oil was collected from the diesel engine of fishing boats operating at South China Sea along the East Coast of Malaysia. Before pyrolysis, the waste oil was filtered through a $100 \mu \mathrm{m}$ filter in order to remove metal particles, carbon soot and other scums so that the remaining particulates were less than $100 \mu \mathrm{m}$. The oil sample was then heated at $110{ }^{\circ} \mathrm{C}$ to eliminate any volatiles and water content. Activated carbon with a size ranging from 0.1 to $0.5 \mathrm{~cm}$ was used as a microwave absorbent to absorb the microwave radiation for conversion into heat to pyrolyze the waste oil.

\subsection{Experimental procedure}

Microwave pyrolysis of waste shipping oil was carried out in a modified $800 \mathrm{~W}$ microwave oven with a frequency of $2.45 \mathrm{GHz}$ as shown in Figure. 1. The pyrolysis system was sealed and nitrogen gas was purged at a flowrate of $200 \mathrm{~mL} / \mathrm{min}$ to maintain an oxygen-free atmosphere. The pyrolysis experiments were performed at $600{ }^{\circ} \mathrm{C}$ using a Type-K thermocouple that is inserted into the middle layer of the waste shipping oil and activated carbon bed. The temperature measured using thermocouple was also validated with the use of an infrared red thermometer, and the results of validation showed good precision with low standard deviations shown in the recorded temperature $\left( \pm 1-3{ }^{\circ} \mathrm{C}\right)$. In addition, the magnetrons of the microwave oven are controlled by an electronic temperature controller that maintains the temperature at the set point within a user-specified tolerance by switching the magnetrons on and off appropriately. $50 \mathrm{~g}$ of waste shipping oil and different amounts of activated carbon (termed as "carbon to waste" or " $\mathrm{C} / \mathrm{W}$ " ratios) were added to a quartz reactor to produce different ratios of $\mathrm{C} / \mathrm{W}$ of $1: 0.5,1: 1,1: 1.5,1: 2$. The volatile products generated in the pyrolysis reaction left the reactor and passed through a condensation system and either condensed into pyrolysis oil or were collected as incondensable pyrolysis gases which can be sampled before being vented from the system, whereas the non-volatile char products were collected after the reactor was cooled to the room temperature. 
$10^{\text {TH }}$ INTERNATIONAL CONFERENCE ON SUSTAINABLE ENERGY AND ENVIRONMENTAL Protection (June $27^{\mathrm{TH}}-30^{\mathrm{TH}}, 2017$, Bled, SLOVEnia), WASte ENERGy AND MANAGEMENT

W.Adibah Wan Mahari, N. Fatihah Zainuddin, N. Ling Ma \& S. Shiung Lam: Production of Diesel-Like Oil as Potential Fuel from Microwave-Assisted Pyrolysis of Waste Shipping Oil

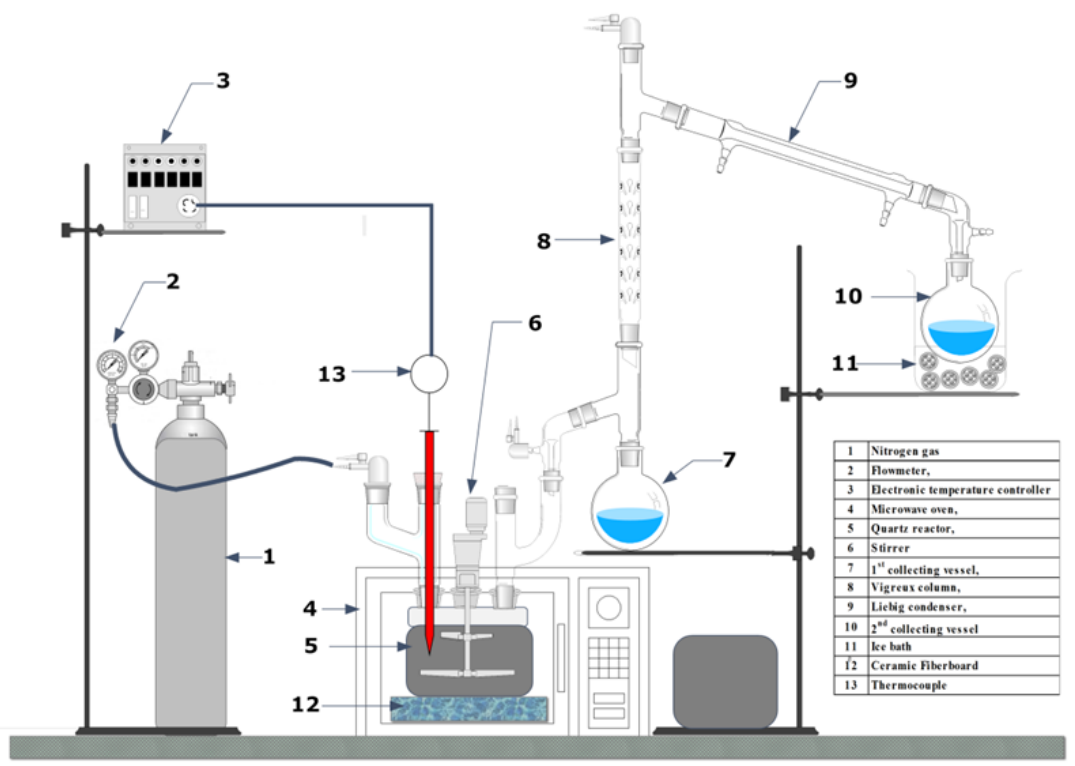

Figure 1. Schematic diagram of microwave pyrolysis system.

The yield of pyrolysis oil was calculated from addition of the weight of the collecting vessels after pyrolysis experiment, and the amount of the char product was determined by measuring the weight change in the reactor and its contents before and after the process. The gas yield was determined by calculating the mass difference.

\subsection{Analytical methods}

The elemental analysis of oil sample was performed to determine the content of carbon, hydrogen, nitrogen, sulphur and oxygen using Vario MACRO Elemental Analyzer (Elementar Analysemsysteme GmbH, Germany). The chemical compositions of oil sample were determined using a 6890 GC-MS instrument (Agilent Technologies, Santa Clara, CA, USA) equipped with a mass spectrometer detector. The column used was a HP-5MS 5\% Phenyl Methyl Siloxane (length $30 \mathrm{~m}$, diameter $250 \mu \mathrm{m}$, film thickness $0.25 \mu \mathrm{m})$. The oven had an initial temperature of $30^{\circ} \mathrm{C}$ with a holding time of $1 \mathrm{~min}$. The oven temperature was then programmed from $30{ }^{\circ} \mathrm{C}$ to $300{ }^{\circ} \mathrm{C}$ at $5{ }^{\circ} \mathrm{C} / \mathrm{min}$. Helium was used as a carrier gas at a constant flow rate of $7 \mathrm{~mL} / \mathrm{min}$. Sample injection volume was 1 $\mu \mathrm{L}$ and $10 \mu \mathrm{L}$ syringe was used to inject the sample into GC instrument. Before injection $0.1 \mathrm{~mL}$ of oil samples were diluted in $0.9 \mathrm{~mL}$ hexane to reduce the viscosity or concentration of oil samples. The compounds were identified by matching their mass spectra to the mass spectra database. Each compound is quantified by the integrated area of the corresponding peak on the mass spectrometer chromatogram. The concentration of each compound was calculated as a percentage of the total area of all peaks in the analysis. 
$10^{\mathrm{TH}}$ INTERNATIONAL CONFERENCE ON SUSTAINABLE ENERGY AND ENVIRONMENTAL 25 Protection (June $27^{\mathrm{TH}}-30^{\mathrm{TH}}, 2017$, Bled, SLOVEnia), WASTE ENERGY AND

MANAGEMENT

W.Adibah Wan Mahari, N. Fatihah Zainuddin, N. Ling Ma \& S. Shiung Lam: Production of Diesel-Like Oil as Potential Fuel from Microwave-Assisted Pyrolysis of Waste Shipping Oil

The calorific value of the oil sample was also determined according to ASTM D240 using a 1341 Plain Jacket bomb calorimeter instrument (Parr Instrument Company, Moline, USA).

\section{$3 \quad$ Results and discussion}

\subsection{Characterization of waste shipping oil as pyrolysis feedstock}

The characteristics of waste shipping oil are examined and shown in Table 1 . The waste oil consisted of high carbon and hydrogen content that also resulted in the high calorific value of the oil, which was found to be $45 \mathrm{MJ} / \mathrm{kg}$. Waste shipping oil primarily comprised of $\mathrm{C}_{11}-\mathrm{C}_{45}$ aliphatic hydrocarbons $(87 \%)$, while the remaining $13 \%$ was unidentified by GCMS analysis. The results suggest that waste shipping oil can be a suitable pyrolysis feedstock since the high energy content with long-chained hydrocarbons could be pyrolyzed and converted into light hydrocarbons for potential use as a fuel.

Table 1. Characteristics of waste shipping oil

\begin{tabular}{|c|c|}
\hline Properties & Waste Shippng Oil \\
\hline \multicolumn{2}{|c|}{ Chemical compositions (peak area \%) ${ }^{\mathrm{a}}$} \\
\hline Alkanes & 81 \\
\hline Cycloalkanes & 1 \\
\hline Alkenes & 5 \\
\hline \multicolumn{2}{|c|}{ Carbon Compounds (peak area $\%)^{\mathrm{a}}$} \\
\hline $\mathrm{C}_{11}-\mathrm{C}_{15}$ & 5 \\
\hline $\mathrm{C}_{16}-\mathrm{C}_{20}$ & 42 \\
\hline $\mathrm{C}_{21}-\mathrm{C}_{30}$ & 27 \\
\hline $\mathrm{C}_{31}-\mathrm{C}_{45}$ & 13 \\
\hline \multicolumn{2}{|c|}{$\begin{array}{l}\text { Polycyclic Aromatic Hydrocarbons (PAH) (peak area } \\
\%)^{\mathrm{a}}\end{array}$} \\
\hline Anthracene & 5 \\
\hline \multicolumn{2}{|l|}{ Elemental analysis (wt\%) } \\
\hline $\mathrm{C}$ & 84.3 \\
\hline $\mathrm{H}$ & 13.6 \\
\hline $\mathrm{N}$ & 0.9 \\
\hline$S$ & 0.13 \\
\hline $\mathrm{O}$ & 1.08 \\
\hline Calorific value $(\mathrm{MJ} / \mathrm{kg})$ & 45 \\
\hline
\end{tabular}

${ }^{a}$ Compound detected in peak area \% of the chromatogram from GCMS analysis 
$10^{\mathrm{TH}}$ INTERNATIONAL CONFERENCE ON SUSTAINABLE ENERGY AND ENVIRONMENTAL Protection (June $27^{\mathrm{TH}}-30^{\mathrm{TH}}, 2017$, Bled, Slovenia), WASte ENERGy AND MANAGEMENT

W.Adibah Wan Mahari, N. Fatihah Zainuddin, N. Ling Ma \& S. Shiung Lam: Production of Diesel-Like Oil as Potential Fuel from Microwave-Assisted Pyrolysis of Waste Shipping Oil

\subsection{Temperature profile of microwave pyrolysis of waste shipping oil}

The temperature profiles of microwave pyrolysis of waste shipping oil at different waste to carbon ratios are demonstrated in Figure. 2 (a). It can be seen that the heating rate increased with the increase of $\mathrm{C} / \mathrm{W}$ ratio. A C/W ratio of 1:0.5 showed the lowest heating rate $\left(8^{\circ} \mathrm{C} / \mathrm{min}\right)$ and the maximum temperature that was achieved within 60 minutes was $430{ }^{\circ} \mathrm{C}$ as shown in Figure. 2(b). C/W ratios of 1:1, 1:1.5, 1:2 showed nearly similar heating rate $\left(11^{\circ} \mathrm{C} / \mathrm{min}\right)$ and the heating achieved the targeted temperature for pyrolysis cracking at $600{ }^{\circ} \mathrm{C}$ within 55 minutes. This shows that the microwave pyrolysis of waste shipping oil required $50 \mathrm{~g}$ or higher amount of activated carbon to achieve the targeted temperature for pyrolysis cracking. Thus, higher $\mathrm{C} / \mathrm{W}$ ratio was found to increase the heating rate during microwave pyrolysis.

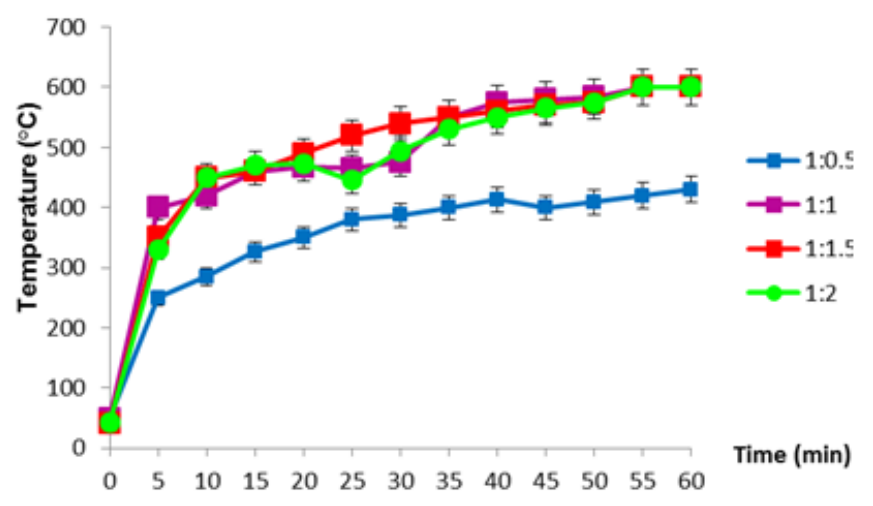

(a)

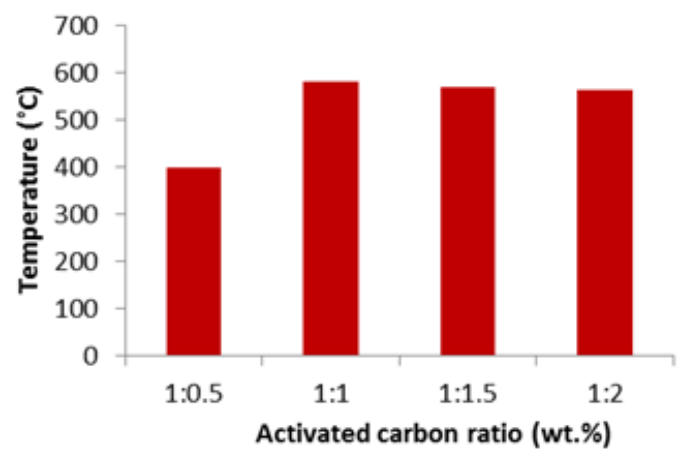

(b)

Figure. 2 Temperature profiles and heating performance of microwave pyrolysis of waste shipping oil(a) $60 \mathrm{~min}$ microwave irradiation time, (b) Maximum temperature recorded at pyrolysis temperature of $600^{\circ} \mathrm{C}$ in 55 to $60 \mathrm{~min}$ microwave irradiation time 
$10^{\mathrm{TH}}$ INTERNATIONAL CONFERENCE ON SUSTAINABLE ENERGY AND ENVIRONMENTAL Protection (June $27^{\mathrm{TH}}-30^{\mathrm{TH}}, 2017$, Bled, SLOVEnia), WASTE ENERGY AND

MANAGEMENT

W.Adibah Wan Mahari, N. Fatihah Zainuddin, N. Ling Ma \& S. Shiung Lam: Production of Diesel-Like Oil as Potential Fuel from Microwave-Assisted Pyrolysis of

Waste Shipping Oil

\subsection{Mass yield and energy recovery of pyrolysis oil}

Figure. 3 shows the product distributions from microwave pyrolysis of waste shipping oil at different $\mathrm{C} / \mathrm{W}$ ratios. Pyrolysis at a $\mathrm{C} / \mathrm{W}$ ratio of 1:0.5 showed the lowest production of gases and pyrolysis oil, which recorded about $5 \mathrm{wt} \%$ and $4 \mathrm{wt} \%$, respectively. A mixture of solid residue and waxy product was formed in a high quantity (up to $91 \mathrm{wt} \%$ ) at this $\mathrm{C} / \mathrm{W}$ ratio. This was probably because incomplete pyrolysis process happened at this C/W ratio where lower amount of activated carbon was used to form the reaction bed. The electron intensity generated by the lower amount of activated carbon was probably not adequate to encourage polarisation among the molecules of activated carbon and waste shipping oil, thus resulting in poor absorbance and conversion of microwave radiation into heat that in turn led to incomplete pyrolysis conversion of waste shipping oil into pyrolysis product $[10,11]$. In addition, the maximum process temperature achieved at a $\mathrm{C} / \mathrm{W}$ ratio of $1: 0.5$ was only $430{ }^{\circ} \mathrm{C}$ compared to $600{ }^{\circ} \mathrm{C}$ obtained by higher $\mathrm{C} / \mathrm{W}$ ratio as presented in Section 3.2. This suggests that higher amount of activated carbon and process temperatures were required to produce higher conversion of waste shipping oil into pyrolysis oil and gases.

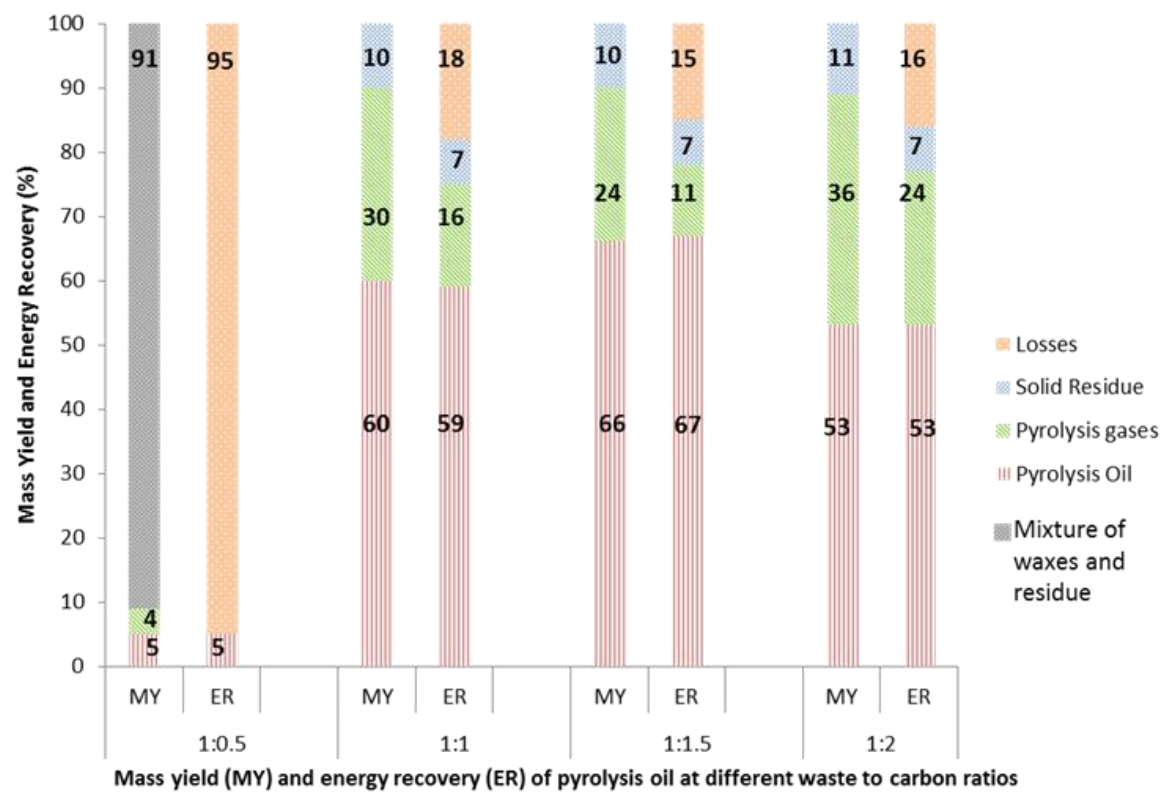

Figure. 3 Mass yield and energy recovery of pyrolysis oil at different C/W ratios.

The highest yield of pyrolysis oil product (up to $66 \mathrm{wt} \%$ ) was observed at 1:1.5 of C/W ratio. This could be attributed to the extensive pyrolysis cracking of waste shipping oil 
$10^{\mathrm{TH}}$ INTERNATIONAL CONFERENCE ON SUSTAINABLE ENERGY AND ENVIRONMENTAL Protection (June $27^{\mathrm{TH}}-30^{\mathrm{TH}}, 2017$, Bled, SLOVEnia), WASte ENERGy AND MANAGEMENT

W.Adibah Wan Mahari, N. Fatihah Zainuddin, N. Ling Ma \& S. Shiung Lam: Production of Diesel-Like Oil as Potential Fuel from Microwave-Assisted Pyrolysis of Waste Shipping Oil

occurred at this $\mathrm{C} / \mathrm{W}$ ratio, which produced volatiles compunds that was condensed into pyrolysis oil products. At higher $\mathrm{C} / \mathrm{W}$ ratio, the higher electron intensity derived from the presence of higher amount of activated carbon was likely to have promoted the cracking of the heavier hydrocarbons in the waste shipping oil into lighter hydrocarbons that are condensable to form pyrolysis oil. As a result, more pyrolysis oil was formed and the gases yield and solid residue were decreased to $24 \mathrm{wt} \%$ and $10 \mathrm{wt} \%$, respectively.

The yield of pyrolysis oil was decreased to $53 \mathrm{wt} \%$ at a C/W ratio of 1:2, while the yield of pyrolysis gases and solid residue was increased up to $35 \mathrm{wt} \%$ and $11 \mathrm{wt} \%$, respectively. The reduction of pyrolysis oil product could be explained by the formation of more hot spots during the pyrolysis reaction, which promoted secondary cracking reactions to form higher amount of pyrolysis gases [12-16]. The increment of solid residue could be explained by carbonization of waste shipping oil which was normally occurred at high process temperature.

Figure. 3 also presents the energy recovery of the pyrolysis products. The energy recovery was estimated based on the formula used in previous studies [5, 17]. Pyrolysis performed at $1: 1.5$ of $\mathrm{C} / \mathrm{W}$ ratio showed the highest energy recovery $(\sim 85 \%)$, followed by $1: 2$ of $\mathrm{C} / \mathrm{W}$ ratio $(\sim 84 \%)$ and 1:1 of $\mathrm{C} / \mathrm{W}$ ratio $(\sim 82 \%)$. Pyrolysis performed at 1:0.5 of $\mathrm{C} / \mathrm{W}$ ratio showed poor energy recovery and recorded the highest energy losses ( 95\%). This was because incomplete pyrolysis occurred at this condition which led to the production of waxy compounds and unwanted residues.

\subsection{Elemental composition of pyrolysis oil}

The results from elemental analysis have shown that carbon and hydrogen represent the main element present in the pyrolysis oil (Table 3). This contributed to a high $\mathrm{H} / \mathrm{C}$ atomic ratio ( $>2)$, which indicated an abundant presence of aliphatic hydrocarbons in the pyrolysis oil. As the $\mathrm{C} / \mathrm{W}$ ratio increased (1:1 to $1: 2)$, the concentration of sulphur $(<0.08$ wt.\%) and oxygen $(<0.7 \mathrm{wt} . \%)$ in the pyrolysis oil were lower than that present in the original waste shipping oil (Table 3 ). This suggests the effective role of activated carbon as a reductant during pyrolysis cracking to remove the sulphur and oxygenated compunds in waste shipping oil. 
$10^{\mathrm{TH}}$ INTERNATIONAL CONFERENCE ON SUSTAINABLE ENERGY AND ENVIRONMENTAL Protection (June $27^{\mathrm{TH}}-30^{\mathrm{TH}}, 2017$, Bled, SLOVEnia), WASTE ENERGY AND

MANAGEMENT

W.Adibah Wan Mahari, N. Fatihah Zainuddin, N. Ling Ma \& S. Shiung Lam: Production of Diesel-Like Oil as Potential Fuel from Microwave-Assisted Pyrolysis of

Waste Shipping Oil

Table 3. Properties of pyrolysis oil obtained at different $\mathrm{C} / \mathrm{W}$ ratio

\begin{tabular}{|l|l|l|l|l|l|}
\hline $\begin{array}{l}\text { Elemental } \\
\text { composition } \\
\text { (wt\%) }\end{array}$ & $\mathbf{W S O}^{\mathbf{a}}$ & \multicolumn{4}{|c|}{ Carbon to waste ratios } \\
\cline { 3 - 6 } & & $1: 0.5$ & $1: 1$ & $1: 1.5$ & $1: 2$ \\
\hline $\mathrm{C}$ & 84.3 & 82.2 & 83.8 & 84.5 & 84.2 \\
\hline $\mathrm{H}$ & 13.6 & 14.6 & 15.0 & 14.3 & 14.2 \\
\hline $\mathrm{N}$ & 0.91 & 1.14 & 1.08 & 1.03 & 0.93 \\
\hline $\mathrm{S}$ & 0.13 & 0.16 & 0.08 & 0.02 & 0.04 \\
\hline $\mathrm{O}$ & 1.08 & 2.00 & 0.13 & 0.15 & 0.70 \\
\hline $\mathrm{H} / \mathrm{C}(\mathrm{mol} / \mathrm{mol})$ & 1.93 & 2.12 & 2.13 & 2.20 & 2.02 \\
\hline $\mathrm{H} / \mathrm{O}(\mathrm{mol} / \mathrm{mol})$ & 201 & 117 & 1878 & 1486 & 322 \\
\hline $\mathrm{O} / \mathrm{C}(\mathrm{mol} / \mathrm{mol})$ & 0.012 & 0.012 & 0.0011 & 0.0014 & 0.006 \\
\hline $\begin{array}{l}\text { Calorific } \\
\text { value } \\
\text { (MJ/Kg) }\end{array}$ & 45 & 42 & 44 & 46 & 45 \\
\hline
\end{tabular}

${ }^{a}$ Waste shipping oil

However, higher concentration of nitrogen was detected in the pyrolysis oil compared with the original waste shipping oil. It can therefore be assumed that some nitrogen content in the activated carbon may have reacted with the waste shipping oil during pyrolysis cracking and generated nitrogen-containing components in pyrolysis oil. The pyrolysis oil can be upgraded through refinery such as hydrotreating or catalytic cracking to transform the pyrolysis oil into a high quality fuel.

Pyrolysis oil obtained at the $\mathrm{C} / \mathrm{W}$ ratio of 1:1.5 showed the most favourable properties to be upgraded to a diesel fuel. The pyrolysis oil was detected to have a calorific value (46 $\mathrm{MJ} / \mathrm{kg}$ ) nearly comparable to diesel and low contents of oxygen $(0.15 \mathrm{wt} \%)$ and sulphur $(0.02 \mathrm{wt} \%)$, thus showing promising features as a 'cleaner' fuel source with potentially reduced formation of tar (an oxygenated byproduct) and low emission of SOx during the use of the oil as fuel in combustion process.

\section{$4 \quad$ Conclusions}

Higher $\mathrm{C} / \mathrm{W}$ ratio promoted pyrolysis cracking of waste shipping oil to produce a yield of up to $66 \mathrm{wt} \%$ of pyrolysis oil. The pyrolysis oil showed a high $\mathrm{H} / \mathrm{C}$ atomic ratio and comprised of $\mathrm{C}_{5}-\mathrm{C}_{15}$ hydrocarbons which shows the potential to be used as fuel. The pyrolysis oil produced at $\mathrm{C} / \mathrm{W}$ ratios of 1:1.5 and 1:2 showed high calorific value (44-46 $\mathrm{MJ} / \mathrm{kg}$ ) nearly comparable to diesel fuel. The oil was also detected to have low contents of oxygen $(<0.7 \mathrm{wt} \%)$ and sulphur $(<0.08 \mathrm{wt} \%)$, thus showing promising features as a 
$10^{\text {TH }}$ INTERNATIONAL CONFERENCE ON SUSTAINABLE ENERGY AND ENVIRONMENTAL Protection (June $27^{\mathrm{TH}}-30^{\mathrm{TH}}, 2017$, Bled, SLOVENIA), WASTE ENERGY AND

MANAGEMENT

W.Adibah Wan Mahari, N. Fatihah Zainuddin, N. Ling Ma \& S. Shiung Lam: Production of Diesel-Like Oil as Potential Fuel from Microwave-Assisted Pyrolysis of Waste Shipping Oil

'cleaner' fuel source. The results indicate that microwave-assisted pyrolysis shows great promise as an alternative to transform waste shipping oil into a fuel source.

\section{Acknowledgements}

The authors acknowledges the financial support by the Ministry of Science, Technology, and Innovation Malaysia (MOSTI), Ministry of Higher Education Malaysia (MOHE), and University Malaysia Terengganu for the conduct of the research under the E-Science fund (UMT/RMC/SF/13/52072(5), Vot No: 52072), the Fundamental Research Grant Scheme (Project No: FRGS/1/2013/TK05/UMT/02/2, Vot No: 59296), and the Research Acculturation Grant Scheme (Project No: RAGS/2012/UMT/TK07/3, Vot No: 57085).

\section{References}

[1] Bengtsson S, Fridell E, Andersson K. Environmental assessment of two pathways towards the use of biofuels in shipping. Energy Policy. 2012;44:451-63.

[2] Yang M. Shipping and maritime transport. 2011.

[3] Singh A, Asmath H, Chee CL, Darsan J. Potential oil spill risk from shipping and the implications for management in the Caribbean Sea. Marine Pollution Bulletin. 2015;93(12):217-27.

[4] Wan Mahari W, Zainuddin N, Wan Nik W, Chong C, Lam S. Pyrolysis Recovery of Waste Shipping Oil Using Microwave Heating. Energies. 2016;9(10):780.

[5] Lam SS, Wan Mahari WA, Jusoh A, Chong CT, Lee CL, Chase HA. Pyrolysis using microwave absorbents as reaction bed: An improved approach to transform used frying oil into biofuel product with desirable properties. Journal of Cleaner Production. 2017;147:263-72.

[6] Lam SS, Russell AD, Lee CL, Chase HA. Microwave-heated pyrolysis of waste automotive engine oil: Influence of operation parameters on the yield, composition, and fuel properties of pyrolysis oil. Fuel. 2012;92(1):327-39.

[7] Aboagye D, Banadda N, Kiggundu N, Kabenge I. Assessment of orange peel waste availability in ghana and potential bio-oil yield using fast pyrolysis. Renewable and Sustainable Energy Reviews. 2017;70:814-21.

[8] Kabir G, Hameed BH. Recent progress on catalytic pyrolysis of lignocellulosic biomass to high-grade bio-oil and bio-chemicals. Renewable and Sustainable Energy Reviews. 2017;70:945-67.

[9] Menéndez JA, Arenillas A, Fidalgo B, Fernández Y, Zubizarreta L, Calvo EG, et al. Microwave heating processes involving carbon materials. Fuel Processing Technology. 2010;91(1):1-8.

[10] Lam SS, Chase HA. A Review on Waste to Energy Processes Using Microwave Pyrolysis. Energies. 2012;5(12):4209-32.

[11] Suriapparao DV, Vinu R. Resource recovery from synthetic polymers via microwave pyrolysis using different susceptors. Journal of Analytical and Applied Pyrolysis. 2015;113:701-12.

[12] Huang Y-F, Chiueh P-T, Kuan W-H, Lo S-L. Microwave pyrolysis of lignocellulosic biomass: Heating performance and reaction kinetics. Energy. 2016;100:137-44.

[13] Huang Y-F, Shih C-H, Chiueh P-T, Lo S-L. Microwave co-pyrolysis of sewage sludge and rice straw. Energy. 2015;87:638-44. 
$10^{\mathrm{TH}}$ INTERNATIONAL CONFERENCE ON SUSTAINABLE ENERGY AND ENVIRONMENTAL

W.Adibah Wan Mahari, N. Fatihah Zainuddin, N. Ling Ma \& S. Shiung Lam: Production of Diesel-Like Oil as Potential Fuel from Microwave-Assisted Pyrolysis of Waste Shipping Oil

[14] Li YZ, Wu SX, Yu XL, Bao RM, Wu ZK, Wang W, et al. Optimization of pyrolysis efficiency based on optical property of semicoke in terahertz region. Energy. 2017;126:2027.

[15] Wang N, Chen D, Arena U, He P. Hot char-catalytic reforming of volatiles from MSW pyrolysis. Applied Energy. 2017;191:111-24.

[16] Tian L, Shen B, Xu H, Li F, Wang Y, Singh S. Thermal behavior of waste tea pyrolysis by TG-FTIR analysis. Energy. 2016;103:533-42.

[17] Lam SS, Wan Mahari WA, Cheng CK, Omar R, Chong CT, Chase HA. Recovery of diesellike fuel from waste palm oil by pyrolysis using a microwave heated bed of activated carbon. Energy. 2016;115:791-9. 
$32 \quad 10^{\text {TH }}$ INTERNATIONAL CONFERENCE ON SUSTAINABLE ENERGY AND ENVIRONMENTAL

Protection (June $27^{\mathrm{TH}}-30^{\mathrm{TH}}, 2017$, Bled, SLOVENiA), WAste ENERGY AND

MANAGEMENT 
$10^{\mathrm{TH}}$ InTERnational CONFEREnCE ON Sustainable ENERgy AND

Environmental Protection (June 27 $7^{\mathrm{TH}}-30^{\mathrm{TH}}, 2017$, BLed, Slovenia), WASTE ENERGY AND MANAGEMENT

J. Krope, A.Ghani Olabi, D. Goričanec \& S. Božičnik

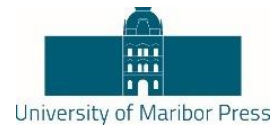

\title{
Numerical Simulation of Refuse-Derived Fuel Thermo- Chemical Conversion in a Waste-to-Energy Plant
}

\author{
Michela Costa, Christian Curcio, Daniele Piazzullo, VitTorio Rocco \& \\ RAFFAELE TUCCILLO
}

\begin{abstract}
Waste management is a major issue resulting in economic costs and environmental impact. Among different waste treatments, incineration is the solution for energy recovery in terms of both electric power and heat generation. Thermo-chemical conversion of organic materials, as biomass or Refuse-Derived Fuel (RDF), is a typical two-phase process with the solid material subjected to concurring sub-processes as drying and release of volatile compounds, and the released syngas undergoing gaseous combustion.

In the present work, a numerical model for the simulation of the RDF thermal treatment in incineration plants is developed. The assessment of the model is achieved on experimental data comparison, and a parametric analysis that studies the influence of different partitions between the drying and gasification zones on the grid and different values of the wall convective heat transfer coefficient is performed. Both a reduced and a detailed kinetic scheme are employed to simulate gaseous combustion.
\end{abstract}

Keywords: • MSW • freeboard $\bullet \mathrm{CFD} \bullet$ gasification $\bullet$ incineration •

Correspondence Address: Michela Costa, CNR - Istituto Motori, Naples, 1 Piazza Barsanti Eugenio E Matteucci Carlo, Napoli, NA 80125, Italy. e-mail: m.costa@im.cnr.it. Christian Curcio, University "Federico II" of Naples, Corso Umberto I, 40, 80138 Napoli, Italy, e-mail: ch.curcio@studenti.unina.it. Daniele Piazzullo, Ph.D. Student, University of Rome "Tor Vergata", Department of Industrial Engineering, Rome, Via Orazio Raimondo, 18, 00173 Roma, Italy, email: daniele.piazzullo@students.uniroma2.eu. Vittorio Rocco, CNR - Istituto Motori, Naples, 1 Piazza Barsanti Eugenio E Matteucci Carlo, Napoli, NA 80125, Italy, e-mail: v.rocco@im.cnr.it, Raffaele Tuccillo, Professor, University of Naples "Federico II", Corso Umberto I, 40, 80138 Napoli, Italy, e-mail: raffaele.tuccillo@unina.it. 
$10^{\mathrm{TH}}$ INTERNATIONAL CONFERENCE ON SUSTAINABLE ENERGY AND ENVIRONMENTAL Protection (June $27^{\mathrm{TH}}-30^{\mathrm{TH}}, 2017$, BLED, SLOVENiA), WASTE ENERGY AND MANAGEMENT

M. Costa, C. Curcio, D. Piazzullo, V. Rocco \& R. Tuccillo: Numerical Simulation of Refuse-Derived Fuel Thermo-Chemical Conversion in a Waste-to-Energy Plant

Municipal Solid Waste (MSW) treatment and disposal is a major issue of our times, as its production is still growing in the last years. Among different waste treatment solutions, fundamental role is played by MSW incineration with energy recovery. This treatment option has the major advantage to allow the combined heat and power (CHP) generation, and to minimize the amount of waste going to landfill, although not completely avoiding it.

The RDF thermal conversion takes place in the plant boiler, where the energy recovery from the flue-gas is also carried out. In moving grate furnaces, which represent the most used technology, a stack of waste is supplied on the grate, where by the effect of the radiation heat transfer from the flame in the freeboard and convective heat transfer from the primary air entering from beneath the grate undergoes to a series of conversion processes, leading to the formation of syngas. A large amount of this combustible is thus released in the freeboard, where its combustion takes place with the supply of a secondary air stream.

The operation of waste-to-energy plants inevitably implies the production of greenhouse gases and the emission of harmful species to the human health. Dioxins are one of the most dangerous of these compounds. The European Directive $[1,2]$ on the incineration plants therefore fixes strict rules concerning the temperature and the residence time of the combustion products within the combustion chamber.

Therefore, the characterization of phenomena occurring in a RDF combustor is strongly demanded for assisting its maintenance and normative compliance.

Nowadays, CFD represents a valuable tool for the characterization of the combustion process at a high level of detail, whose employment in waste-to-energy systems simulation is fairly recent. With reference to grate-fired boilers, some works treat the modelling of combustion in the gas phase with a gross approximation of the process occurring in the solid bed [3,4], while other works only investigate with great detail the thermal conversion of the solid bed [5,6]. Few scientific papers dealing with the coupling of thermo-chemical conversion of the solid fuel and combustion process in the gaseous phase are available in the literature [6,7].

The present work aims at the validation and improvement of a CFD model of a real-scale waste-to-energy plant operating in central Italy, which couples the thermo-chemical conversion process of solid RDF, simulated through a two-zone OD thermodynamic model, with the gaseous combustion of the released syngas, simulated through a 3D CFD model. 
M. Costa, C. Curcio, D. Piazzullo, V. Rocco \& R. Tuccillo: Numerical Simulation of Refuse-Derived Fuel Thermo-Chemical Conversion in a Waste-to-Energy Plant

\section{RDF thermal conversion: the coupled model}

The coupling of the two numerical models has been carried out using an iterative procedure, whose steps are described in the following:

1. a value of the thermal power incident on the solid RDF bed is assumed;

2. the thermal conversion of solid RDF and, subsequently, the gaseous combustion of the syngas are simulated through the respective models;

3. a new value of thermal power is computed through the 3D CFD model;

4. if the computed thermal power coincides with the assumed value, the simulation is stopped, otherwise it starts again from step 2.

The convergence criterion used is that the difference between the computed thermal power and the assumed one must be smaller than $1 \%$.

\subsection{Solid conversion modelling}

The RDF thermo-chemical conversion in the incineration plant in Pozzilli (Italy) is simulated through a 0D model implemented in Matlab ${ }^{\mathrm{TM}}$, where the solid fuel bed on the grate is schematized through an energy open system approach, constituted by two sequential zones, one for drying, one for thermo-chemical conversion (Figure 1).

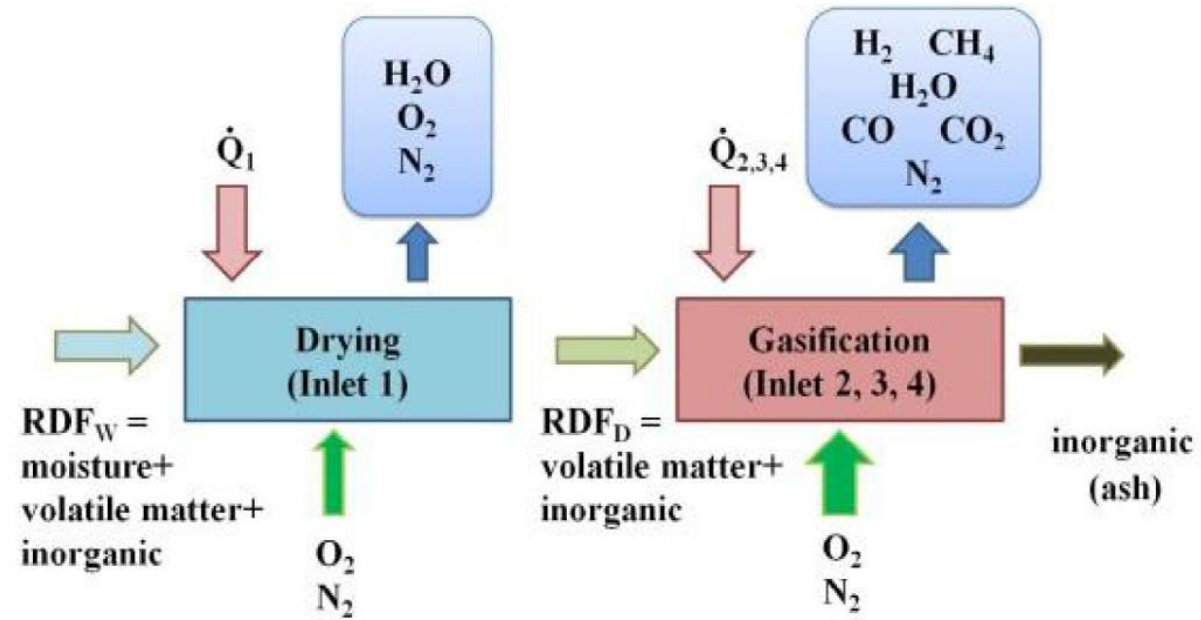

Figure 1. Solid conversion thermodynamic model scheme [8]

The change of parameters along the grate, such as temperature and composition of the released gaseous species, is assumed as reflecting the subdivision of the grate into four parts of the same area, indicated as Inlet 1 to Inlet 4 in Figure 2, the first of which is associated to the drying process while the others to the thermo-chemical conversion. 
According to the grate subdivision described above, which takes also into account the actual distribution of the primary air inflow, it is assumed that the first $25 \%$ of the grate is interested only by drying, while chemical conversion into volatiles occurs on the remaining $75 \%$.

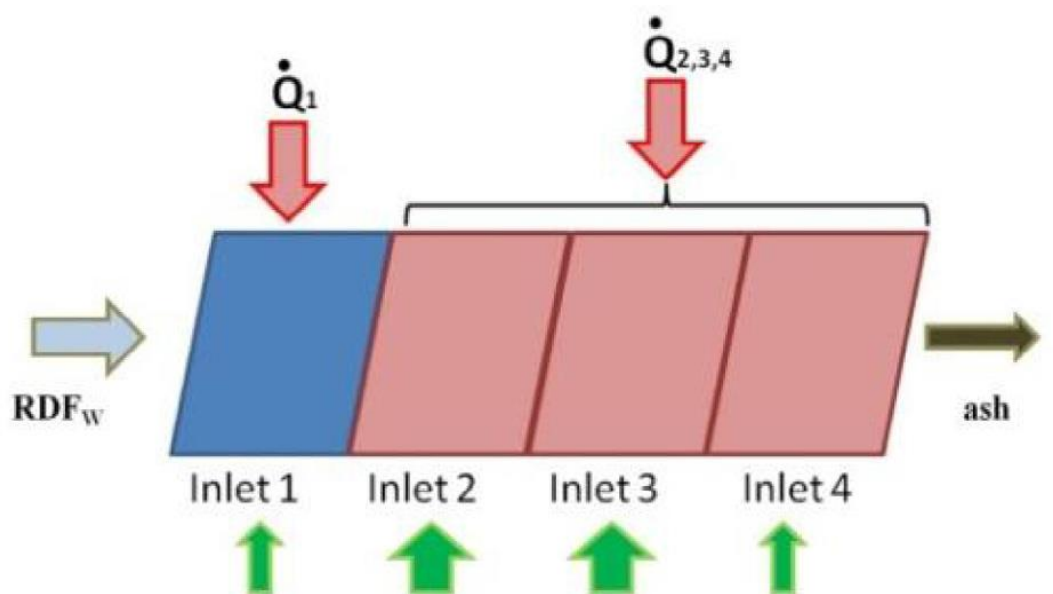

Figure 2. Grate area division between drying and thermo-chemical conversion [8]

In the evaporation region, the model distinguishes between the two cases of partial evaporation and complete evaporation. In the first case, only part of the initial moisture content of the incoming waste is actually converted into vapour in the drying section, while in the second case the RDF comes out of the system as completely dry material. This is clearly visible in Figure 3, which reports the results of a parametric study on the primary air and radiative thermal power amounts, performed on the drying system as a function of the parameter $\beta_{\text {drying }}$, defined as:

$\beta_{\text {drying }}=\frac{\dot{m}_{\text {air }, d}}{\dot{m}_{R D F}}\left[\frac{k g_{\text {air }}}{k g_{R D F}}\right]$

where $\dot{m}_{a i r, d}$ and $\dot{m}_{R D F}$ are the air and RDF mass flow rates entering the system, respectively. 
M. Costa, C. Curcio, D. Piazzullo, V. Rocco \& R. Tuccillo: Numerical Simulation of Refuse-Derived Fuel Thermo-Chemical Conversion in a Waste-to-Energy Plant

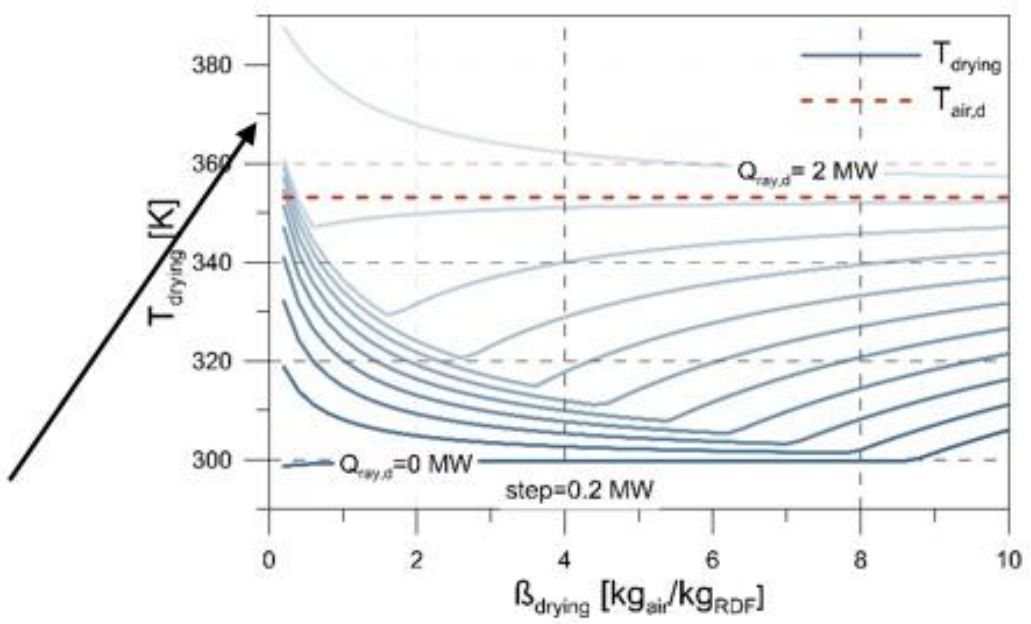

Figure 3. Drying temperature as a function of the parameters $\beta_{\text {drying }}$ and $Q_{\text {ray,d }}$

The diagram shows higher temperatures $\left(\mathrm{T}_{\text {drying }}\right)$ and enhanced evaporation with the growth of the amounts of primary air and radiative thermal power incident on the system $\left(Q_{\text {ray }, d}\right)$.

The RDF thermo-chemical conversion, represented by the red block of Figure 2, is modelled through a specific formulation, analogous to the one presented in the paper by Costa et al. [9]. Gasification is indeed simulated according to the thermo-chemical equilibrium hypothesis between the considered chemical species $\left(\mathrm{H}_{2}, \mathrm{CH}_{4}, \mathrm{CO}, \mathrm{CO}_{2}\right.$, $\mathrm{H}_{2} \mathrm{O}$ and $\mathrm{N}_{2}$ ), with complete oxygen depletion. Steady conditions and a constant atmospheric pressure are assumed. Conservation equations are written for the number of moles of each chemical element $(\mathrm{C}, \mathrm{H}, \mathrm{O}, \mathrm{N})$ together with the equilibrium equations of the chemical reactions of the conversion process, namely water-gas shift, methanation and Boudouard [10]. A parametric study on the primary air amount and the incident radiative thermal power was carried out on the conversion system too, whose results are reported in Figure 4, as a function of the parameter $\beta_{\text {conv }}$, defined as:

$\beta_{\text {conv }}=\frac{\dot{m}_{\text {air,conv }}}{\dot{m}_{R D F, d r y}}\left[\frac{k g_{\text {air }}}{k g_{R D F, d r y}}\right]$

where $\dot{m}_{\text {air,conv }}$ and $\dot{m}_{R D F, d r y}$ are the air and dry RDF mass flow rates entering the system, respectively. 
M. Costa, C. Curcio, D. Piazzullo, V. Rocco \& R. Tuccillo: Numerical Simulation of Refuse-Derived Fuel Thermo-Chemical Conversion in a Waste-to-Energy Plant

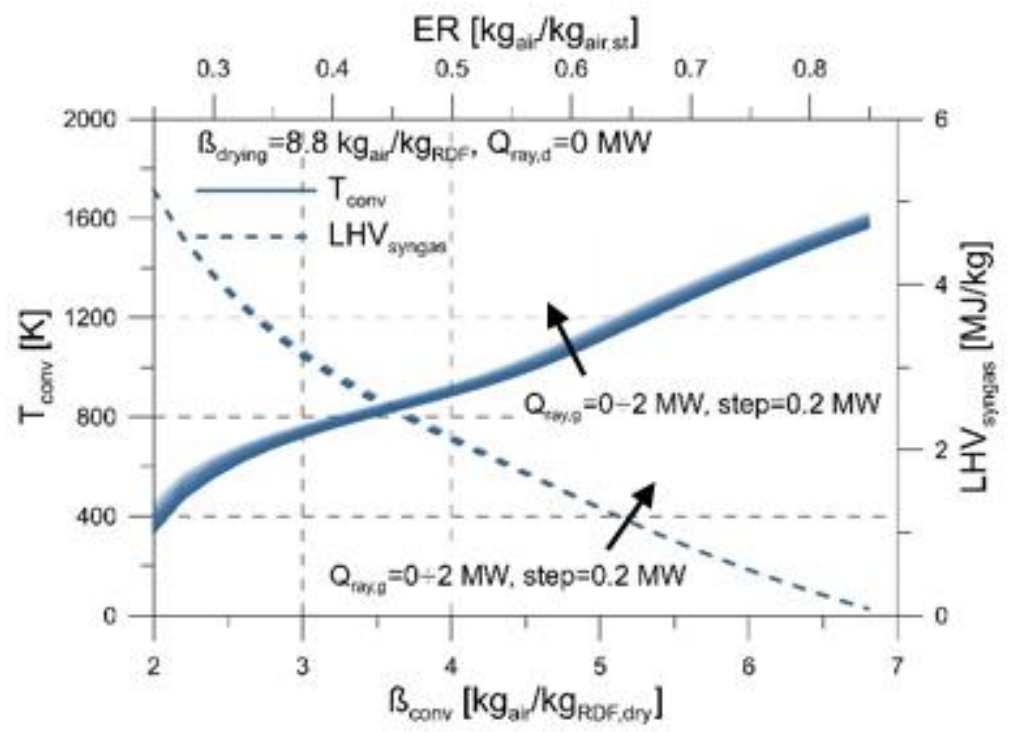

Figure 4. Conversion temperature and lower heating value of the released syngas as a function of the parameters $\beta_{\text {conv }}$ and $Q_{\text {ray,g }}$

The diagram shows a rising trend for the conversion temperatures $\left(\mathrm{T}_{\text {conv }}\right)$ predicted by the model while a descendent trend for the lower heating value of the released syngas ( $\left.\mathrm{LHV}_{\text {syngas }}\right)$ with the growth of the primary air amount. On the other hand, it is evident a slight dependence of both the above-mentioned quantities on the radiative thermal power incident on the system $\left(Q_{\text {ray, }}\right)$, in the investigated range which was chosen around the values employed in the next simulations.

\subsection{Gaseous combustion modelling}

The 3D simulation of the syngas combustion in the freeboard of the combustion chamber is carried out through a properly settled CFD model within Ansys Fluent ${ }^{\mathrm{TM}}$ software environment. 
M. Costa, C. Curcio, D. Piazzullo, V. Rocco \& R. Tuccillo: Numerical Simulation of Refuse-Derived Fuel Thermo-Chemical Conversion in a Waste-to-Energy Plant

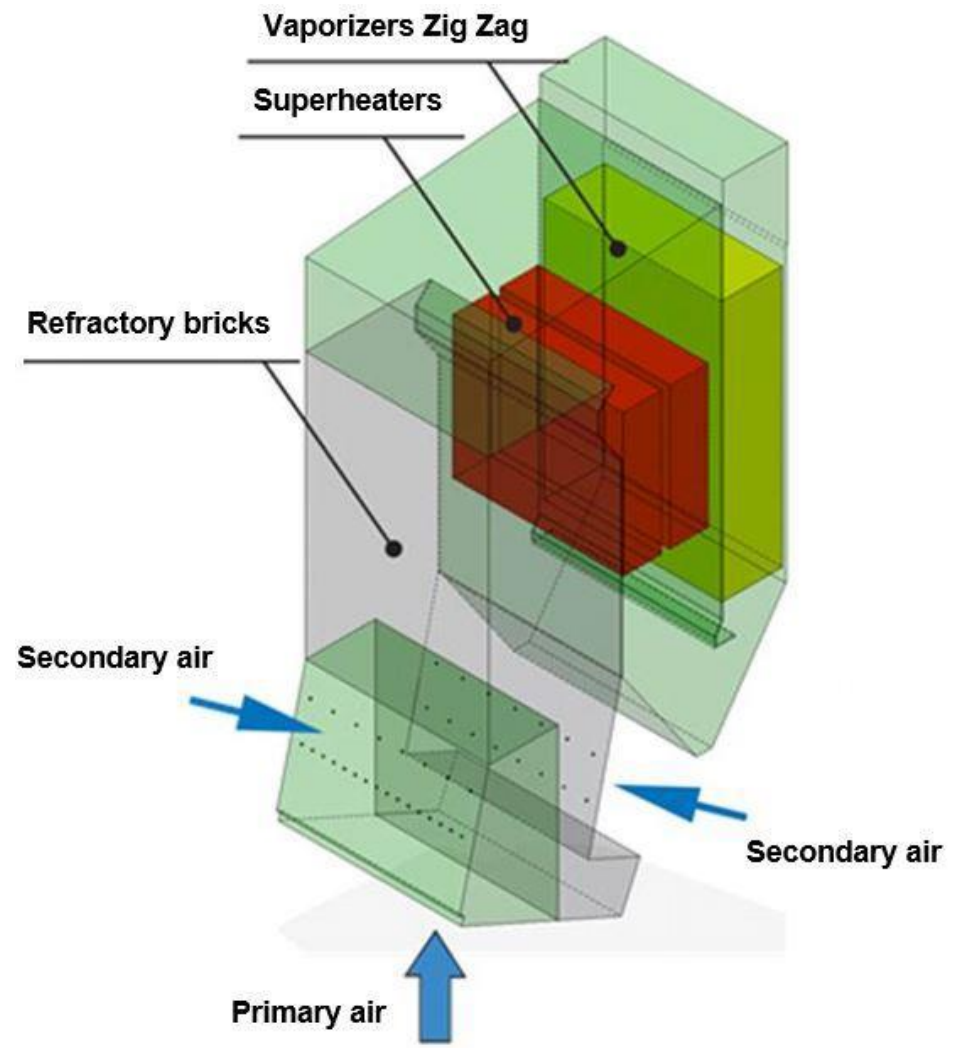

Figure 5. Combustion chamber schematization of the Pozzilli plant [8]

The choice of the computational domain for the simulation of gaseous combustion in the freeboard of Pozzilli plant was made considering the first vertical channel and part of the second one and exploiting the vertical symmetry of the system, whose scheme is reported in Figure 5. 


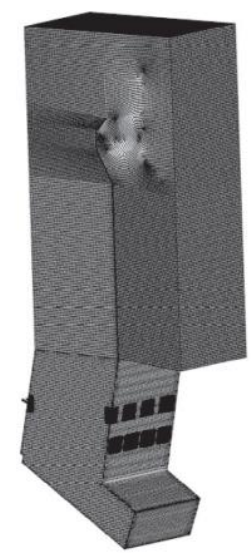

Figure 6. Mesh adopted for the computational domain discretization (2,052,853 cells)

[8]

The discretization of the domain under study assumes a fundamental importance in such numerical models, in terms of accuracy of the solution and of computational time. A compromise solution between these two conflicting objectives was found with the discretization approach described in ref. [8] which led to consider the mesh reported in Figure 6.

The SST (Shear Stress Transport) $k-\omega$ sub-model for turbulence closure [11] in a RANS simulation, considered a good compromise solution between the standard $k-\varepsilon$ and $k-\omega$ models, and the EDC (Eddy Dissipation Concept) approach for combustion [12] are adopted.

Chemical kinetics of syngas reactions, due to its composition, is assumed to follow a twostep reduced kinetic scheme as a first kind of approach, according to the following reactions of oxidation:

$\mathrm{H}_{2}+1 / 2 \mathrm{O}_{2} \rightarrow \mathrm{H}_{2} \mathrm{O}$

$\mathrm{CO}+1 / 2 \mathrm{O}_{2} \rightarrow \mathrm{CO}_{2}$

In all the simulations, in fact, the methane combustion has been neglected, as the heat release associated with its oxidation was verified to be much lower than that of $\mathrm{CO}$ and $\mathrm{H}_{2}$.

In a second phase, a more detailed chemical kinetics is considered, based on the mechanism developed by Jachimowsky [13], for $\mathrm{H}_{2}$ oxidation, and on the one developed by Novosselov [14,15], for CO oxidation. In total, the mechanism is composed by 12 species and 17 reactions. 
M. Costa, C. Curcio, D. Piazzullo, V. Rocco \& R. Tuccillo: Numerical Simulation of Refuse-Derived Fuel Thermo-Chemical Conversion in a Waste-to-Energy Plant

The global heat transfer coefficient, $U\left[W /\left(\mathrm{m}^{2} \mathrm{~K}\right)\right]$, whose value can be defined as boundary condition on the walls of the combustion chamber in the two zones covered and uncovered by refractory material, is estimated through additional numerical simulations according to the methodology presented by the authors in ref. [9]. The calculated values are $17.5 \mathrm{~W} /\left(\mathrm{m}^{2} \mathrm{~K}\right)$ and $1844 \mathrm{~W} /\left(\mathrm{m}^{2} \mathrm{~K}\right)$ in correspondence of the walls with and without refractory, respectively.

\section{$3 \quad$ Results}

In the following, the results obtained through different analysis carried out on the model will be presented and discussed.

\subsection{Drying section extension influence}

The assumption of considering the drying process occurring on a grate section corresponding to the $25 \%$ of the total RDF bed extension is not actually in line with other assumption made in the literature under similar conditions and plant configurations, such as in ref. [16]. Therefore, a parametric analysis was carried out by varying the extension of the drying zone, namely by also considering the drying section varying between the $15 \%$ and $35 \%$ of the bed.

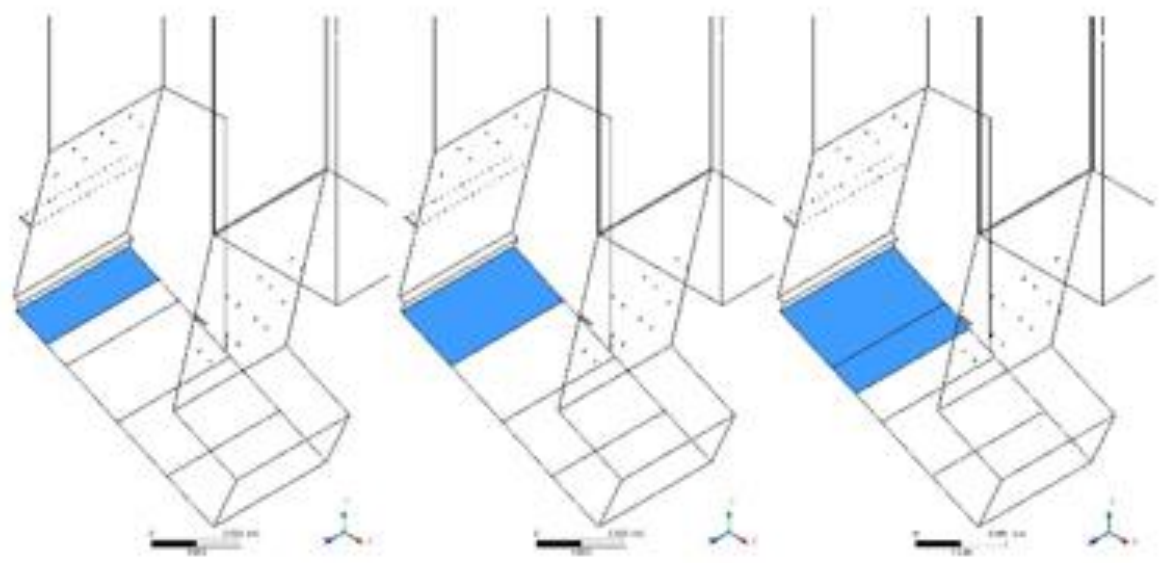

Figure 7. Drying inlet surfaces for the three considered configurations

In Figure 7 the drying inlet surfaces corresponding to the three cases analysed are shown, the middle one being the reference configuration.

A first fundamental result of the simulations is the growing trend of the evaporated fraction of the initial RDF moisture content as a function of the drying section extension, 
as shown in Figure 8. This trend is related to the increase of both $\beta_{\text {drying }}$ and $\dot{Q}_{r a y, d}$ with the drying surface size.

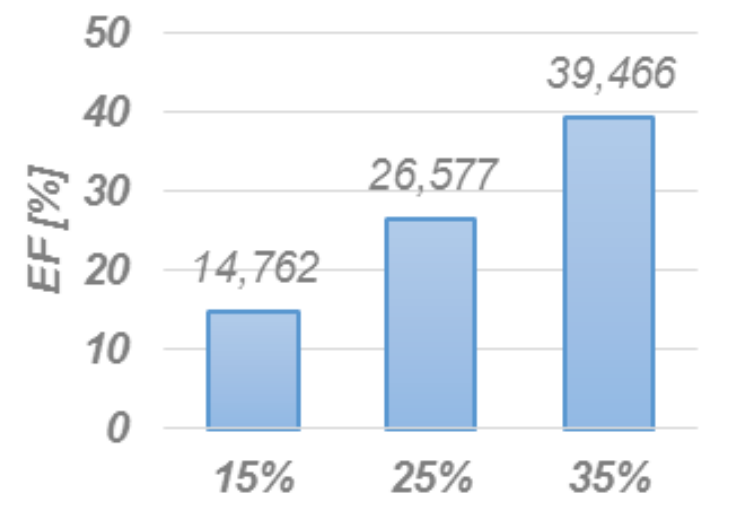

Figure 8. Evaporated fraction of the initial RDF moisture content in the drying section for the three considered sizes
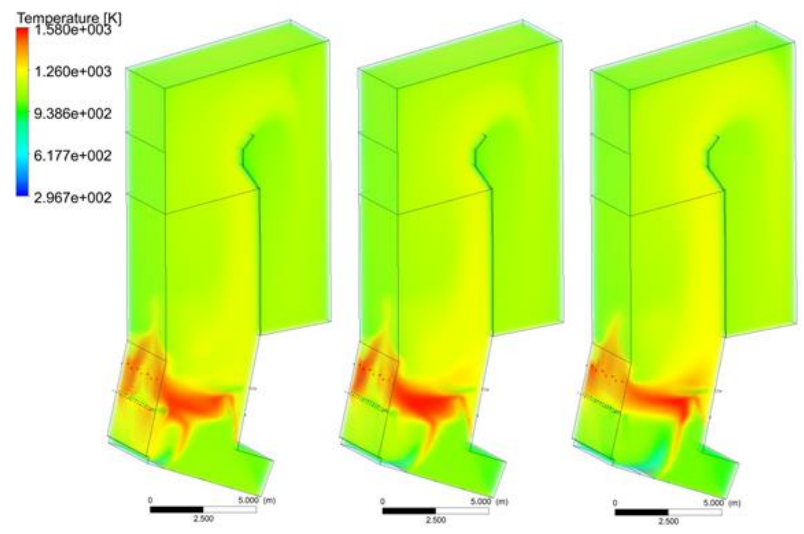

\section{$A_{d} / A_{\text {bed }}=15 \% \quad A_{d} / A_{\text {bed }}=25 \% \quad A_{d} / A_{\text {bed }}=35 \%$}

Figure 9. Temperature contours on the computational domain for the three drying inlet surface sizes

As regards the variables distribution in the $3 \mathrm{D}$ computational domain, the temperature contours on the whole computational domain and the $\mathrm{H}_{2}$ mass fraction on the symmetry plane are reported in Figure 9 and 10. 
M. Costa, C. Curcio, D. Piazzullo, V. Rocco \& R. Tuccillo: Numerical Simulation of Refuse-Derived Fuel Thermo-Chemical Conversion in a Waste-to-Energy Plant
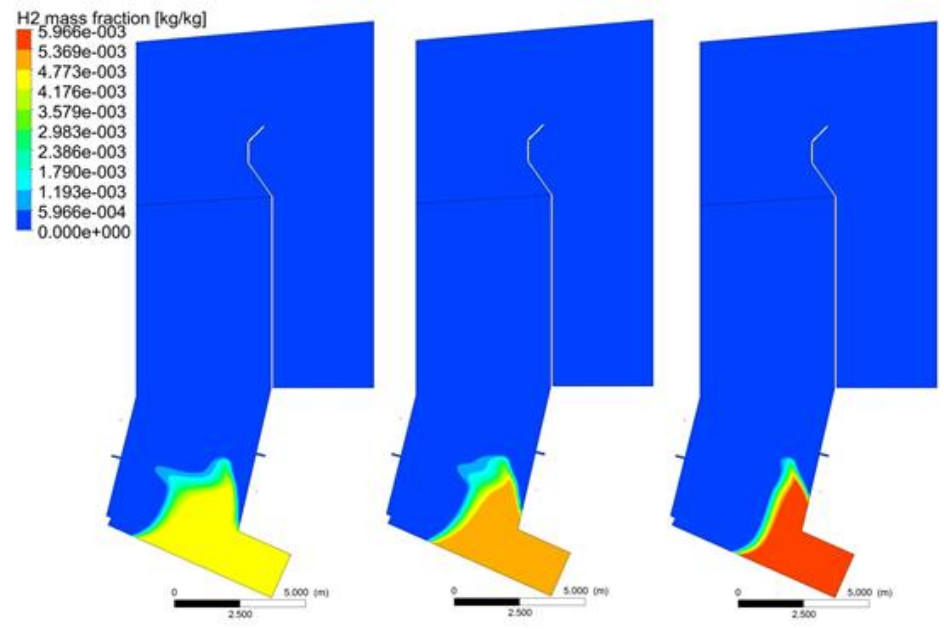

\section{$A_{d} / A_{\text {bed }}=15 \% \quad A_{d} / A_{\text {bed }}=25 \% \quad A_{d} / A_{\text {bed }}=35 \%$}

Figure $10 . \mathrm{H}_{2}$ mass fraction contours on the symmetry plane of the domain for the three drying inlet surface sizes

In order to demonstrate the good predictive capability of the model, even in operative conditions different from those of validation, a parametric study on the heat transfer coefficient imposed on the furnace refractory walls is also performed. Beside the calculated $17.5 \mathrm{~W} / \mathrm{m}^{2} \mathrm{~K}$ one, two more values are considered for the study, reported in Table 1.

Table 1. Values of convective heat transfer coefficient investigated

\begin{tabular}{|c|c|c|}
\hline \multicolumn{3}{|c|}{ 3D CFD model- $A_{\text {drying }}=25 \%\left(A_{\text {bed }}\right)$} \\
\hline \multicolumn{3}{|c|}{$U\left[W /\left(\mathrm{m}^{2} \cdot K\right)\right]$} \\
\hline 10 & $\mathbf{1 7 . 5}$ & 75 \\
\hline
\end{tabular}


M. Costa, C. Curcio, D. Piazzullo, V. Rocco \& R. Tuccillo: Numerical Simulation of Refuse-Derived Fuel Thermo-Chemical Conversion in a Waste-to-Energy Plant

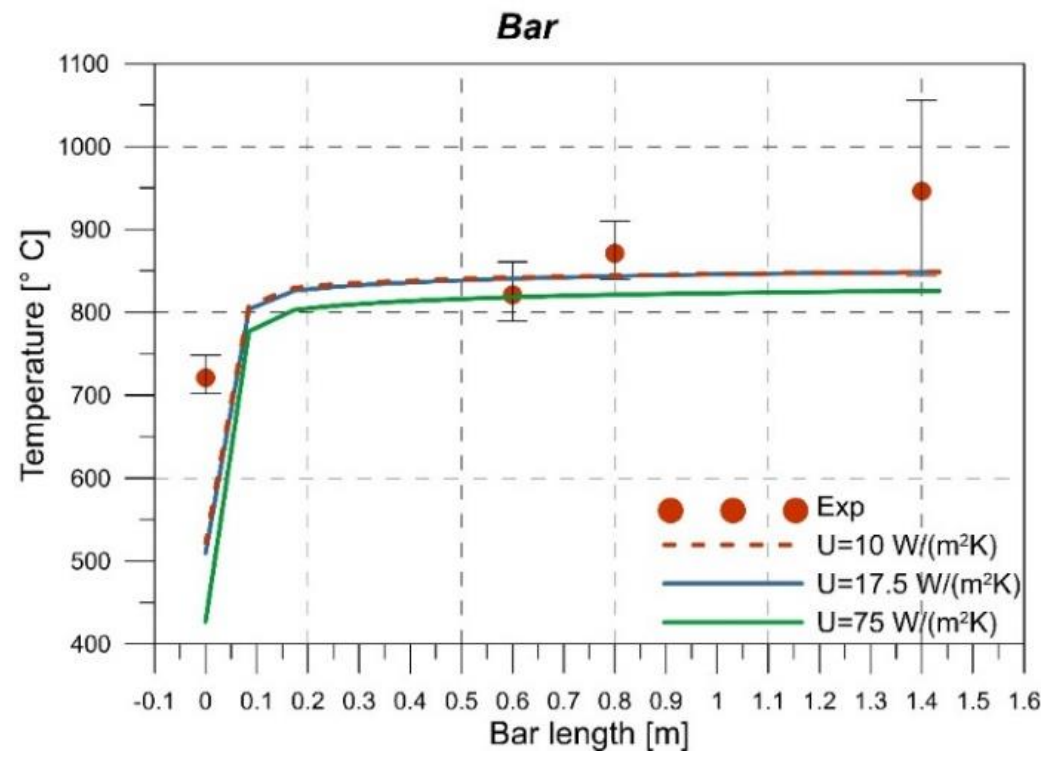

Figure 11. Temperature profiles along the line passing through the measurement points computed with the three values of $U$

Temperature profiles along the lines passing through the measurement points [8] show higher computed temperatures with low values of the heat transfer coefficient, which can simulate operative conditions characterized by the fouling phenomenon. On the other hand, temperatures are lower when the heat exchange is more effective, condition that can be representative of what happens in the real plant after cleaning operations.

\section{$4 \quad$ Detailed kinetics implementation}

The implementation of the detailed kinetic mechanism was carried out on the reference configuration of the system, namely the one with the drying process occurring on the $25 \%$ of the grate extension. 
M. Costa, C. Curcio, D. Piazzullo, V. Rocco \& R. Tuccillo: Numerical Simulation of Refuse-Derived Fuel Thermo-Chemical Conversion in a Waste-to-Energy Plant
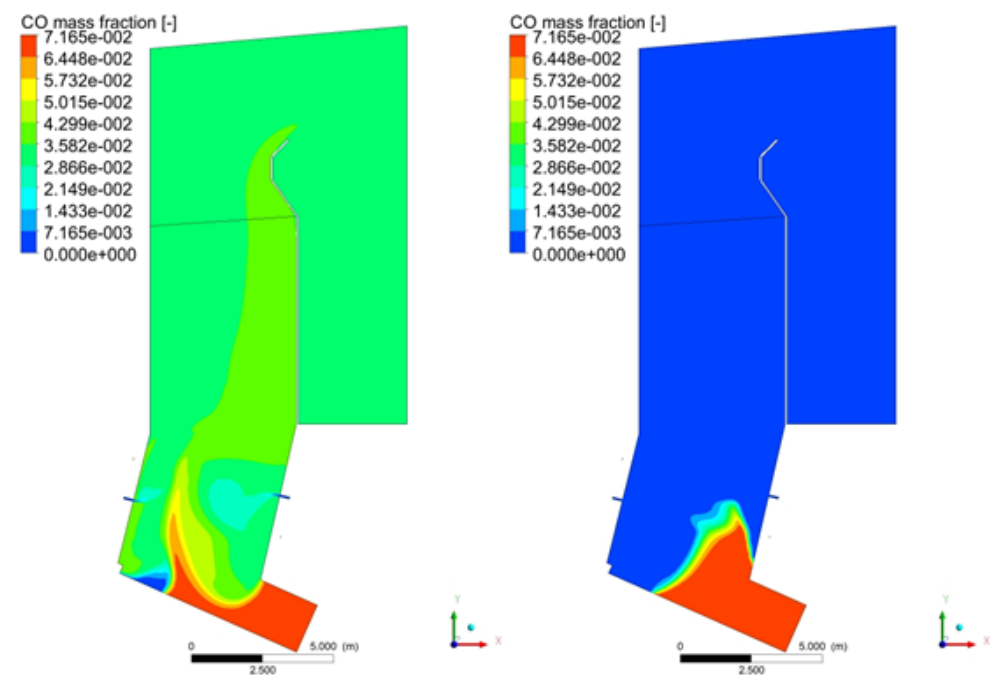

\section{Jachimowski mechanism Two-reaction mechanism}

Figure 12. CO mass fraction contours on the symmetry plane of the domain for the two considered kinetics

The results obtained through this kinetic scheme, compared to the ones with the tworeaction scheme, put into evidence that the reaction zone shape and position are different, the $\mathrm{H}_{2}$ consumption is still complete while $\mathrm{CO}$ reduces only at half of the entering amount (Figure 12).
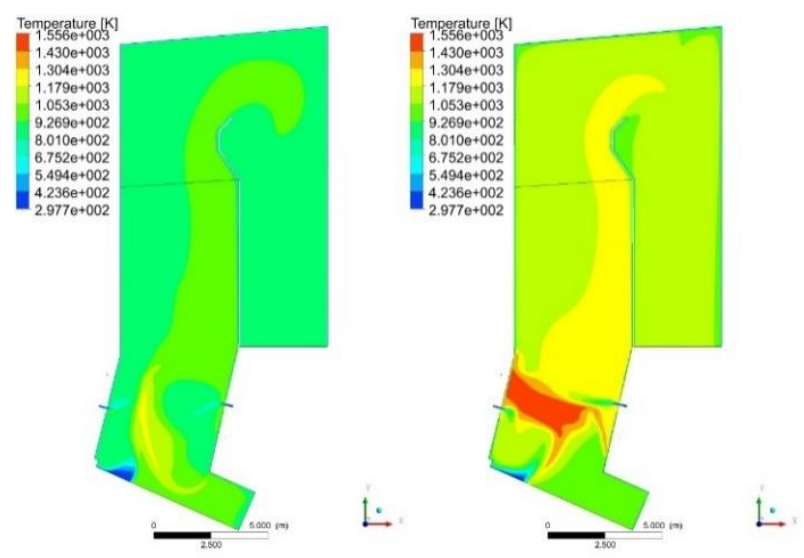

\section{Jachimowski mechanism Two-reaction mechanism}

Figure 13. Temperature contours on the symmetry plane of the domain for the two considered kinetics 
$10^{\text {TH }}$ INTERNATIONAL CONFERENCE ON SUSTAINABLE ENERGY AND ENVIRONMENTAL Protection (June $27^{\mathrm{TH}}-30^{\mathrm{TH}}, 2017$, Bled, Slovenia), WASte ENERGy AND MANAGEMENT

M. Costa, C. Curcio, D. Piazzullo, V. Rocco \& R. Tuccillo: Numerical Simulation of Refuse-Derived Fuel Thermo-Chemical Conversion in a Waste-to-Energy Plant

As a consequence, the amount of molecular oxygen at the outlet of the domain results higher than the measured value (6\%). The temperature field downstream of the reaction zone shows a reduction of about $200 \mathrm{~K}$ (Figure 13), strictly connected to the not full CO oxidation.

The significant deviation between the results and the available experimental data leads to consider a proper tuning of the new employed reaction mechanism, or changes to the turbulence-chemistry interaction model.

\section{$5 \quad$ Conclusions}

The parametric analysis operated on the solid conversion model has shown that, even under several simplifying assumptions, it presents good predictive capability in a wide range of the input parameters.

The parametric study on the drying section size has allowed to establish that the weight of the hypothesis linked to the value of this parameter on the results of the overall system is not so high.

The results obtained with different values of the heat transfer coefficient on the wall of the combustion chamber have shown the capability of the model to predict in the right way the characteristic quantities of the flow, with boundary conditions different those of validation.

The implementation of a detailed chemical kinetics in the 3D CFD model has shown a non-negligible deviation from the experimental data but also a slower oxidation process for the CO. This suggest a better tuning of this mechanism or the use of more complex kinetic schemes to describe the early oxidation stages.

\section{References}

[1] European Environmental Bureau, "New features under the Industrial Emissions Directive", European Environmental Bureau, 2011.

[2] Waste Incineration Directive, "Directive 2000/76/EC of the European Parliament and of the Council of the Incineration of Waste", European Commission, 2000.

[3] C. K. Ryu and S. Choi, "3-Dimensional simulation of air mixing in the MSW incinerators", Combust. Sci. Technolog., vol. 110, pp. 155-170, 1996.

[4] W. Dong and W. Blasiac, "CFD modelling of ecotube in coal and waste grate combustion", Energ. Convers. Manage., vol. 42, pp. 1887-1896, 2001.

[5] Y. B. Yang, V. N. Sharifi and J. Swithenbank, "Effect of air flow rate and fuel moisture on the burning behaviours of biomass and simulated municipal solid wastes in packed beds", Fuel, vol. 83, pp. 1553-1562, 2004.

[6] D. Shin and S. Choi, "The combustion of simulated waste particles in a bed", Combust. Flame, vol. 80, pp. 121-167, 2000. 
M. Costa, C. Curcio, D. Piazzullo, V. Rocco \& R. Tuccillo: Numerical Simulation of Refuse-Derived Fuel Thermo-Chemical Conversion in a Waste-to-Energy Plant

[7] H. H. Frey,, B. Peters, H. Hunsinger and J. Vehlow, "Characterization of municipal solid waste combustion in a grate furnace, Waste Manage., vol. 23, pp. 689-701, 2003.

[8] M. Costa, N. Massarotti, A. Mauro, F. Arpino and V. Rocco, "CFD modelling of a RDF incineration plant", Applied Thermal Engineering, vol. 101, pp. 710-719, 2016.

[9] M. Costa, V. Indrizzi, N. Massarotti and A. Mauro, "Modelling and optimization of an incinerator plant for the reduction of the environmental impact", Int. J. Num. Method H., vol. 25, pp. 1463-1487, 2015.

[10] S. Jarungthammachote and A. Dutta, "Thermodynamic equilibrium model and second law analysis of downdraft waste gasifier", Energy, vo. 32, pp. 1660-1669, 2007.

[11] F. R. Menter, "Zonal two equation k- $\omega$ models for aerodynamic flows", AIAA paper, pp. 93-2996, 1993.

[12] B. F. Magnussen, "On the structure of turbulence and a generalised eddy dissipation concept for chemical reaction in turbulent flow", Proceedings of the $19^{\text {th }}$ ALAA Meeting, 1981.

[13] C. J. Jachimowsky, "An analytical study of hydrogen-air reaction mechanism with application to scramjet combustion", NASA-TP-2791, 1988.

[14] I. V. Novosselov and P. C. Malte, "Development and application of an eight-step global mechanism for CFD and CRN simulation of lean-premixed combustors, ASME, 2007.

[15] M. C. Cameretti and R. Tuccillo, "Combustion features of a bio-fuelled micro-gas turbine", Applied Thermal Engineering, vol. 89, pp. 280-290, 2015.

[16] M. Costa, V. Indrizzi, N. Massarotti, B. Rajh, C. Yin and N. Samec, "Engineering bed models for solid fuel conversion process in grate-fired boilers", Energy, vol. 77, pp. 244253, 2014. 
$10^{\mathrm{TH}}$ INTERNATIONAL CONFERENCE ON SUSTAINABLE ENERGY AND ENVIRONMENTAL

Protection (June $27^{\mathrm{TH}}-30^{\mathrm{TH}}, 2017$, Bled, Slovenia), WASte ENERGy AND

MANAGEMENT 
$10^{\mathrm{TH}}$ InTERnational CONFERENCE ON Sustainable ENERgy AND Environmental Protection (June $27^{\mathrm{TH}}-30^{\mathrm{TH}}$, 2017, Bled, Slovenia), WASTE ENERGY AND MANAGEMENT

J. Krope, A.Ghani Olabi, D. Goričanec \& S. Božičnik

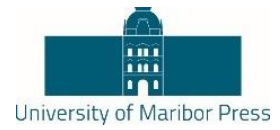

\title{
Waste Gasification with an Advanced 100 kW Dual Fluidized Bed Gasifier
}

\author{
FLORIAN BENEDIKT, JOHANNES CHRISTIAN SCHMID \& HERMANN HOFBAUER
}

\begin{abstract}
Steam gasification enables conversion of heterogeneous solid fuels into a homogeneous gaseous energy carrier. The utilization of residues and waste fractions as fuel for this technology offers a sustainable waste management solution to produce heat and power, secondary fuels and valuable chemicals after several cleaning and upgrading steps of the product gas. However, residues and waste fuels show unfavorable properties for gasification and, therefore, cause technical challenges. Test runs with two different waste fractions, carried out at a fuel flexible 100 $\mathrm{kW}$ gasification pilot plant at TU Wien, are presented: a municipal solid waste fraction and a shredder light fraction. Additionally, the municipal solid waste fraction was mixed with $25 \%$ of lignite - based on the lower heating value - to improve the product gas quality. The product gas compositions and tar, char and dust contents are presented. Performance indicating key figures describe the gasification processes of the test runs.
\end{abstract}

Keywords: • municipal solid waste fraction $\bullet$ shredder light fraction • lignite $\bullet$ calcium oxide $\bullet$ silica sand $\bullet$

CORRESPONDENCE AdDRESS: Florian Benedikt, MSc, Assistant, TU Wien, Faculty of Technical Chemistry, Getreidemarkt 9/166, 1060 Vienna, Austria, e-mail: florian.benedikt@tuwien.ac.at. Johannes Christian Schmid, Ph.D., Assistant, TU Wien, Faculty of Technical Chemistry, Getreidemarkt 9/166, 1060 Vienna, Austria, e-mail: johannes.schmid@tuwien.ac.at. Hermann Hofbauer, Ph.D., Professor, TU Wien, Faculty of Technical Chemistry, Getreidemarkt 9/166, 1060 Vienna, Austria, e-mail: hermann.hofbauer@tuwien.ac.at.

https://doi.org/10.18690/978-961-286-063-9.5

ISBN 978-961-286-063-9

(C) 2017 University of Maribor Press

Available at: http://press.um.si. 
$10^{\mathrm{TH}}$ INTERNATIONAL CONFERENCE ON SUSTAINABLE ENERGY AND ENVIRONMENTAL Protection (June $27^{\mathrm{TH}}-30^{\mathrm{TH}}, 2017$, Bled, SLovenia), WASte ENERGy AND MANAGEMENT

F. Benedikt, J. Christian Schmid \& H. Hofbauer: Waste Gasification with an Advanced $100 \mathrm{~kW}$ Dual Fluidized Bed Gasifier

\section{$1 \quad$ Introduction}

Dual fluidized bed (DFB) steam gasification offers a well-proven technology to produce heat, electricity, secondary liquid or gaseous energy carriers and valuable chemicals from solid fuels. Utilizing residues and waste fractions provides a high potential to produce these goods in a sustainable, eco-friendly way. The technology was demonstrated for the gasification of wood at industrial scale in (i) Güssing, Austria ( $8 \mathrm{MW}_{\text {th }}$ fuel power) [1], (ii) Oberwart, Austria $\left(8.5 \mathrm{MW}_{\text {th }}\right)$ [2], (iii) Senden, Germany (15 $\left.\mathrm{MW}_{\text {th }}\right)$ [3] and (iv) Gothenburg, Sweden (33 $\mathrm{MW}_{\text {th }}$ ) [4]. However, some of these plants suffer from economic weakness if high-grade wood chips are used as solid fuel- especially because the fuel costs increased significantly in the last decade. Thus, fuel flexibility in order to use low-cost fuels is an important issue. However, alternative fuels often show unfavorable properties for gasification and, therefore, cause technical challenges and limitations. At TU Wien, an advanced $100 \mathrm{~kW}_{\text {th }}$ gasification pilot plant was developed to enable detailed investigations on these alternative fuel types [5].

The basic principle of the DFB steam gasification process is shown in Figure 1. Thereby, solid fuels are converted into a nitrogen-free product gas, which mainly consists of hydrogen $\left(\mathrm{H}_{2}\right)$, carbon monoxide $(\mathrm{CO})$, carbon dioxide $\left(\mathrm{CO}_{2}\right)$, methane $\left(\mathrm{CH}_{4}\right)$, ethylene $\left(\mathrm{C}_{2} \mathrm{H}_{4}\right)$, and other hydro-carbons in smaller amounts. The process is based on two interconnected reactors, the gasification reactor (GR) and the combustion reactor (CR).

product gas

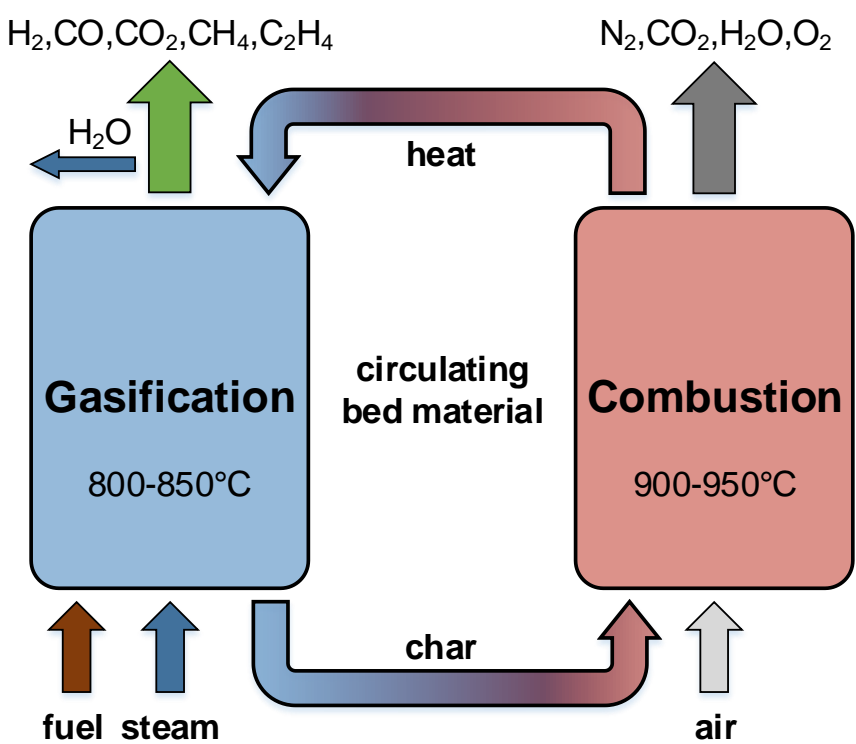

Figure 1. Basic principle of the DFB steam gasification process 
$10^{\mathrm{TH}}$ INTERNATIONAL CONFERENCE ON SUSTAINABLE ENERGY AND ENVIRONMENTAL Protection (June $27^{\mathrm{TH}}-30^{\mathrm{TH}}, 2017$, Bled, Slovenia), WASte ENERGy AND

MANAGEMENT

F. Benedikt, J. Christian Schmid \& H. Hofbauer: Waste Gasification with an Advanced 100 kW Dual Fluidized Bed Gasifier

The circulating bed material is heated up in the combustion reactor and provides the necessary heat for the overall endothermic steam gasification. Unconverted fuel from the gasification reactor, the so-called char, supplies the fuel for the combustion reactor, which is fluidized with air. A flue gas (FG) stream is leaving the combustion reactor and the valuable product gas (PG) stream is leaving the gasification reactor. Thereby, a highcalorific nitrogen-free product gas with a lower heating value (LHV) in the range of 10 to $16 \mathrm{MJ} / \mathrm{Nm}_{\mathrm{db}}^{3}$ is generated.

Olivine sand is typically used as circulating bed material in DFB steam gasification plants. Olivine is a common magnesium iron silicate based mineral in the subsurface of the earth and after some time of operation in a DFB gasification plant, it forms calciumrich layers on its surface caused by interactions with biomass ash. At high temperatures these outer layers form calcium oxide and lead to an increased catalytic activity with respect to an enhanced water gas shift reaction and tar reduction by steam reforming [6]. Therefore, calcite sand as bed material for DFB steam gasification is a focus of investigations at $\mathrm{TU}$ Wien in the last years. Pure calcite $\left(\mathrm{CaCO}_{3}\right)$ will be calcined to calcium oxide $(\mathrm{CaO})$ in the reactor system at temperatures higher than $800^{\circ} \mathrm{C}$. This type of bed material shows relatively low abrasion resistance in comparison to commercially applied bed materials for fluidized bed applications like olivine or silica sand. Therefore, a gravity separation equipment for the smooth separation of bed material particles at the exit of the gasifier as well as combustor is implemented in the advanced design of the $100 \mathrm{~kW}_{\text {th }}$ pilot plant at TU Wien [7]. It has to be mentioned that the mixture of calcite and silica sand offers an interesting combination because of a higher heating capacity of silica sand than for calcite. This is important for a proper energy (heat) transport from the $\mathrm{CR}$ to the GR. Silica sand serves as main heat carrier and $\mathrm{CaO}$ as catalytic active bed material. Both silica sand and calcite are cheap and available worldwide, in contrast to olivine.

\section{Experimental setup and applied methods}

\section{$2.1 \quad$ The advanced $100 \mathrm{~kW}_{\text {th }}$ DFB steam gasification pilot plant}

Figure 2 shows the advanced design of the $100 \mathrm{~kW}_{\text {th }}$ DFB steam gasification pilot plant at TU Wien. Fuel is fed onto a bubbling fluidized bed in the lower part of the gasification reactor. The upper gasification reactor is designed as countercurrent column with hot bed material flowing down and product gas streaming upwards. An enhanced gas-solid contact and higher residence time in these turbulent fluidized zones promote tar cracking and reforming reactions. The gasification and combustion reactor are equipped with gravity separators for the coarser bed material, which allows for a smooth separation in contrast to cyclones, where higher gas and particle velocities occur. Downstream cyclones separate fine particles for each reactor to obtain a nearly particle-free product gas. 
F. Benedikt, J. Christian Schmid \& H. Hofbauer: Waste Gasification with an Advanced 100 kW Dual Fluidized Bed Gasifier

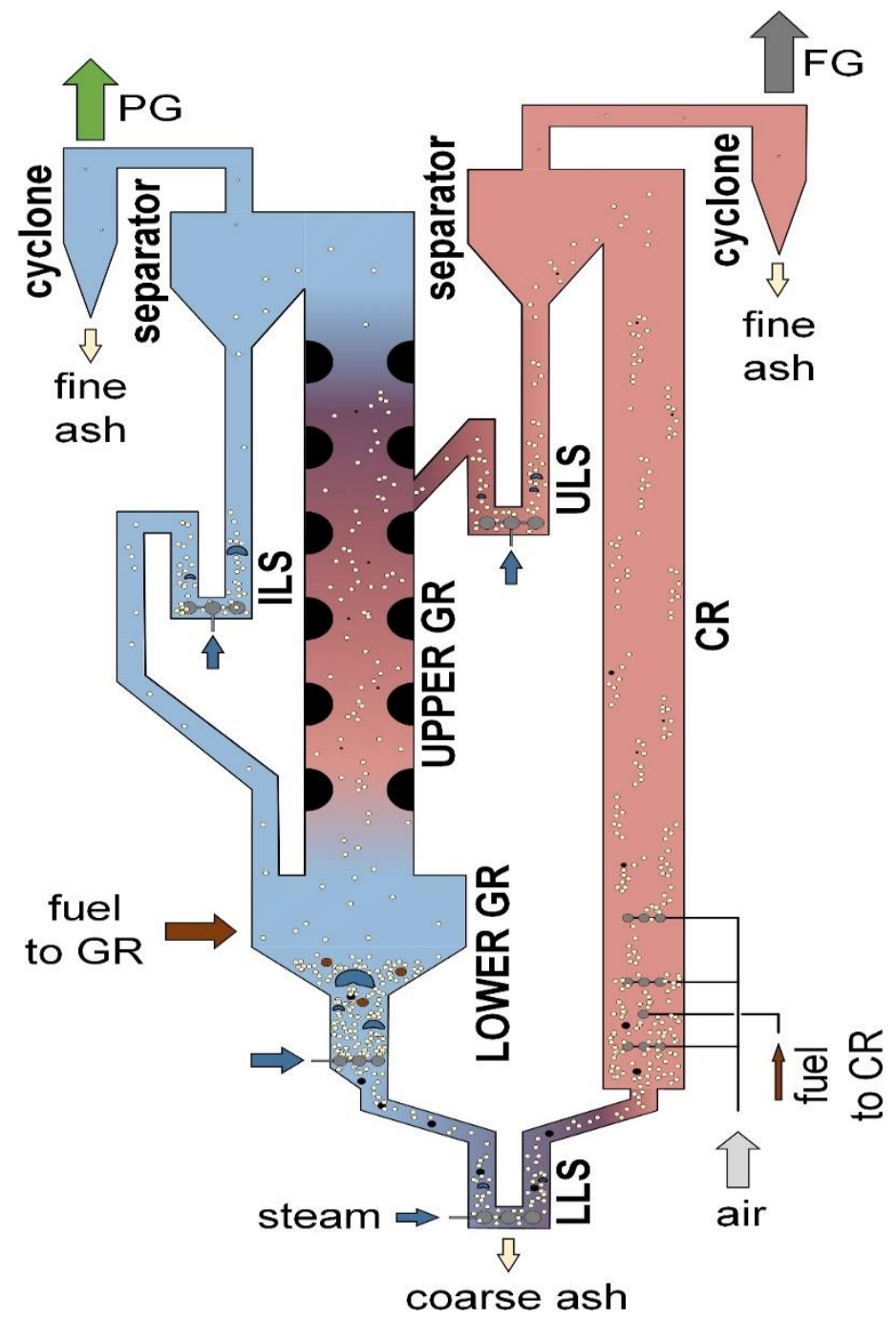

Figure 2. Advanced design of the $100 \mathrm{~kW}_{\text {th }}$ DFB steam gasification pilot plant

The lower loop seal (LLS) and the upper loop seal (ULS) connect the two reactors and close the global circulation of bed material particles. The internal circulation in the gasification reactor is realized through the internal loop seal (ILS). Additional fuel in the combustion reactor compensates for the relatively high specific heat losses in this small pilot plant and enables control of the gasification temperature for the gasification experiments. The fuel flexible pilot plant is in operation since 2014 and experimental results from test runs with different fuels or bed materials so far can be found elsewhere [7]-[10]. 
$10^{\mathrm{TH}}$ INTERNATIONAL CONFERENCE ON SUSTAINABLE ENERGY AND ENVIRONMENTAL 53 Protection (June $27^{\mathrm{TH}}-30^{\mathrm{TH}}, 2017$, Bled, SLOVENIA), WASTE ENERGY AND

MANAGEMENT

F. Benedikt, J. Christian Schmid \& H. Hofbauer: Waste Gasification with an Advanced 100 kW Dual Fluidized Bed Gasifier

\subsection{Bed materials, fuels and measurement equipment}

Table 1 shows the bed materials for the gasification test runs with shredder light fraction (SLF), municipal solid waste fraction (MWF), and lignite (LIG). The experiment with a mixture of MWF and LIG was carried out with $25 \%$ of MWF based on the lower heating value of the total fuel input into the gasification reactor. Due to the high temperature in the reactor system, the calcite in the bed material was calcined to calcium oxide during steady state operation.

Table 1. Bed materials for the gasification test runs

\begin{tabular}{|l|l|l|l|l|}
\hline \multirow{2}{*}{ Bed material } & \multirow{2}{*}{ Unit } & \multicolumn{3}{|l|}{ Experiment } \\
\cline { 3 - 5 } & & SLF & MWF & MWF+LIG \\
\hline Silica Sand & wt.\% & 0 & 0 & 66.7 \\
\hline Calcite & wt.\% & 100 & 100 & 33.3 \\
\hline
\end{tabular}

Table 2 shows the proximate and ultimate analyses of the used fuels. The ash content for SLF was higher compared to the other fuels. The share of volatiles was higher for the waste fractions than for lignite. The waste fractions showed a high energy content compared to biogenic fuels, like wood pellets with similar water contents $(\sim 17 \mathrm{MJ} / \mathrm{kg})$.

Table 2. Proximate and ultimate analyses of feedstock

\begin{tabular}{|c|c|c|c|c|}
\hline Parameter & Unit & SLF & MWF & LIG \\
\hline Water content & wt. $\%$ & 7.05 & 1.55 & 13.0 \\
\hline Ash content & wt. $\%_{\mathrm{db}}$ & 12.0 & 7.8 & 4.2 \\
\hline Carbon $(\mathrm{C})$ & wt. $\%_{\text {daf }}$ & 80.5 & 76.1 & 68.4 \\
\hline Hydrogen $(\mathrm{H})$ & wt. $\%_{\text {daf }}$ & 12.2 & 11.3 & 3.9 \\
\hline Nitrogen $(\mathrm{N})$ & wt. $\%_{\text {daf }}$ & 0.49 & 0.57 & 0.88 \\
\hline Oxygen $(\mathrm{O})^{\mathrm{a}}$ & wt. $\%_{\text {daf }}$ & 4.35 & 10.76 & 26.37 \\
\hline Sulphur (S) & wt. $\%_{\text {daf }}$ & 0.25 & 0.08 & 0.40 \\
\hline Chlorine $(\mathrm{Cl})$ & wt. $\%_{\text {daf }}$ & 2.21 & 1.19 & 0.05 \\
\hline Volatile matter & wt. $\%_{\text {daf }}$ & 91.8 & 93.3 & 54.1 \\
\hline Fixed carbon & wt. $\%_{\text {daf }}$ & 8.2 & 6.7 & 45.9 \\
\hline Lower heating value (LHV), moist & $\mathrm{MJ} / \mathrm{kg}$ & 28.7 & 31.0 & 20.8 \\
\hline
\end{tabular}

a: calculated by difference to $100 \mathrm{wt} . \%_{\text {daf }}$

Table 3 presents the applied online measurement devices or measurement principles of the pilot plant. For a more detailed description see [8]. Additionally, $\mathrm{C}_{2} \mathrm{H}_{4}$ was analyzed every 15 minutes by a gas chromatograph (Perkin Elmer ARNEL - Clarus 500). An adapted standardized arrangement of sampling equipment was used to analyze the content of dust, char and gravimetric tar in the product gas. Single tar components are measured by gas chromatography coupled with mass spectrometry (GCMS). For tar measurements at the advanced pilot plant, toluene is used as solvent instead of isopropanol, because the solubility for tar in toluene is higher and the water content in the PG can be measured 
$10^{\mathrm{TH}}$ INTERNATIONAL CONFERENCE ON SUSTAINABLE ENERGY AND ENVIRONMENTAL Protection (June $27^{\mathrm{TH}}-30^{\mathrm{TH}}, 2017$, Bled, SLOVEnia), WASte ENERGy AND MANAGEMENT

F. Benedikt, J. Christian Schmid \& H. Hofbauer: Waste Gasification with an Advanced $100 \mathrm{~kW}$ Dual Fluidized Bed Gasifier

simultaneously in a simple way. However, toluene itself cannot be detected with this setup as GCMS tar component. A more detailed description of the tar, char and dust measurement procedure is given by Aigner et al. [11]. The tar dew point was calculated via the online calculation tool from the Energy Research Center of the Netherlands [12].

Table 3. Setup of online measurement devices for the gasification test runs

\begin{tabular}{|l|l|l|}
\hline Parameter & Device or principle & Number \\
\hline Temperature & thermocouple (type K) & $100+$ \\
\hline Pressure & pressure sensor (Kalinsky DS2) & $70+$ \\
\hline $\begin{array}{l}\text { Main air and steam } \\
\text { flows }\end{array}$ & Krohne (float-type or vortex) & 8 \\
\hline Fuel input & Scales $^{\mathrm{a}}$ & 2 \\
\hline Main gas composition & Rosemount NGA 2000 $^{\text {ba }}$ & $12^{\mathrm{b}}$ \\
\hline
\end{tabular}

a: additionally through calibration of the feeding system (via dosing screws)

b: number of online measured FG and PG components

\subsection{Process simulation}

For evaluation and validation of the gathered process data, the process simulation software IPSEpro was used. A comprehensive model library for biomass gasification has been developed by Pröll and Hofbauer [13]. It enables the user to calculate important values via mass and energy balances, which cannot be measured directly. Thereby, following performance indicating key figures were calculated:

The steam to carbon ratio $\varphi_{\mathrm{SC}}$ is given in Equation (1). $\varphi_{\mathrm{SC}}$ is used to enable comparison between test runs with different fuels.

$$
\varphi_{\mathrm{SC}}=\frac{\dot{\mathrm{m}}_{\mathrm{steam}, \mathrm{GR}}+\dot{\mathrm{m}}_{\mathrm{H} 2 \mathrm{O}, \mathrm{GR}, \mathrm{fuel}}}{\dot{\mathrm{m}}_{\mathrm{C}, \mathrm{GR}, \mathrm{fuel}}}
$$

The product gas yield PGY is presented in Equation (2) and gives the ratio between dry PG to dry and ash-free fuel introduced into the GR.

$$
\mathrm{PGY}=\frac{\dot{\mathrm{V}}_{\mathrm{PG}}}{\dot{\mathrm{m}}_{\mathrm{GR}, \text { fuel,daf }}}
$$

The steam steam-related water conversion $\mathrm{X}_{\mathrm{H} 2 \mathrm{O}}$ gives the relation of water consumed and water introduced into the GR and is shown in Equation (3).

$$
\mathrm{X}_{\mathrm{H} 2 \mathrm{O}}=\frac{\dot{\mathrm{m}}_{\text {steam,GR }}+\dot{\mathrm{m}}_{\mathrm{H} 2 \mathrm{O}, \mathrm{GR}, \text { fuel }}-\dot{\mathrm{m}}_{\mathrm{H} 2 \mathrm{O}, \mathrm{PG}}}{\dot{\mathrm{m}}_{\text {steam,GR }}+\dot{\mathrm{m}}_{\mathrm{H} 2 \mathrm{O}, \mathrm{GR}, \text { fuel }}}
$$


F. Benedikt, J. Christian Schmid \& H. Hofbauer: Waste Gasification with an Advanced 100 kW Dual Fluidized Bed Gasifier

Equation (4) gives the cold gas efficiency $\eta_{\mathrm{CG}}$, which describes the ratio of chemical energy in the product gas to the chemical energy in the fuel, which is fed into the gasification reactor, based on the LHV.

$$
\eta_{\mathrm{CG}}=\frac{\dot{\mathrm{V}}_{\mathrm{PG}} \cdot \mathrm{LHV}_{\mathrm{PG}}}{\dot{\mathrm{m}}_{\mathrm{GR}, \text { fuel }} \cdot \mathrm{LHV}_{\mathrm{GR} \text {,ful }}} \cdot 100
$$

Equation (5) describes the overall cold gas efficiency $\eta_{\mathrm{CG}, \mathrm{o}}$, which is an extension of the cold gas efficiency. $\eta_{\mathrm{CG}, \mathrm{o}}$ also takes the fuel which is fed into the combustion reactor as well as the relatively high heat losses of the $100 \mathrm{~kW}_{\text {th }}$ pilot plant into account

$$
\eta_{\mathrm{CG}, \mathrm{o}}=\frac{\dot{\mathrm{V}}_{\mathrm{PG}} \cdot \mathrm{LHV}_{\mathrm{PG}}}{\dot{\mathrm{m}}_{\mathrm{GR}, \text { fuel }} \cdot \mathrm{LHV}_{\mathrm{GR}, \text { fuel }}+\dot{\mathrm{m}}_{\mathrm{CR} \text {,fuel }} \cdot \mathrm{LHV}_{\mathrm{CR}, \text { fuel }}-\dot{\mathrm{Q}}_{\text {loss }}} \cdot 100
$$

\section{$3 \quad$ Results and discussion}

Table 4 presents the main operation parameters for the gasification test runs.

Table 4. Main operation parameters

\begin{tabular}{|l|c|c|c|c|}
\hline Parameter & Unit & SLF & MWF & $\begin{array}{c}\text { MWF } \\
\text { +LIG }\end{array}$ \\
\hline$\varphi_{\text {SC }}$ & $\begin{array}{c}\mathrm{kg}_{\text {H2O }} / \\
\mathrm{kg}_{\mathrm{C}}\end{array}$ & 2.1 & 1.9 & 2.2 \\
\hline Fuel input into GR & $\mathrm{kW}$ & 113 & 110 & 123 \\
\hline Fuel input into CR & $\mathrm{kW}$ & 55 & 55 & 65 \\
\hline$\dot{\mathrm{Q}}_{\text {loss }}$ & $\mathrm{kW}$ & 21 & 29 & 22 \\
\hline $\begin{array}{l}\text { Mean temp. in the lower } \\
\text { GR }\end{array}$ & ${ }^{\circ} \mathrm{C}$ & 807 & 754 & 838 \\
\hline Temp. in upper GR & ${ }^{\circ} \mathrm{C}$ & 976 & 965 & 985 \\
\hline Mean temp. in the CR & ${ }^{\circ} \mathrm{C}$ & 995 & 998 & 1008 \\
\hline
\end{tabular}

For all experiments, the steam to carbon ratio was in a narrow range. The mean temperature in the lower gasification reactor at the fuel input is given. Besides, the temperature in the upper countercurrent gasification reactor at the re-entry point of hot bed material coming from the ULS is described as well. The temperature in the CR is a mean value over the height. The different temperature profiles over the reactor system can be explained by two factors: (i) the influence of the fuel composition - with a focus on contents of volatiles (see Table 2), (ii) the use of different bed materials: silica sand has a higher heat capacity than calcium oxide. Figure 3 shows the dry main product gas composition and water content in the product gas for the tested fuels. 
$10^{\text {TH }}$ INTERNATIONAL CONFERENCE ON SUSTAINABLE ENERGY AND ENVIRONMENTAL Protection (June $27^{\mathrm{TH}}-30^{\mathrm{TH}}, 2017$, Bled, SLOVENIA), WASTE ENERGY AND MANAGEMENT

F. Benedikt, J. Christian Schmid \& H. Hofbauer: Waste Gasification with an Advanced 100 kW Dual Fluidized Bed Gasifier
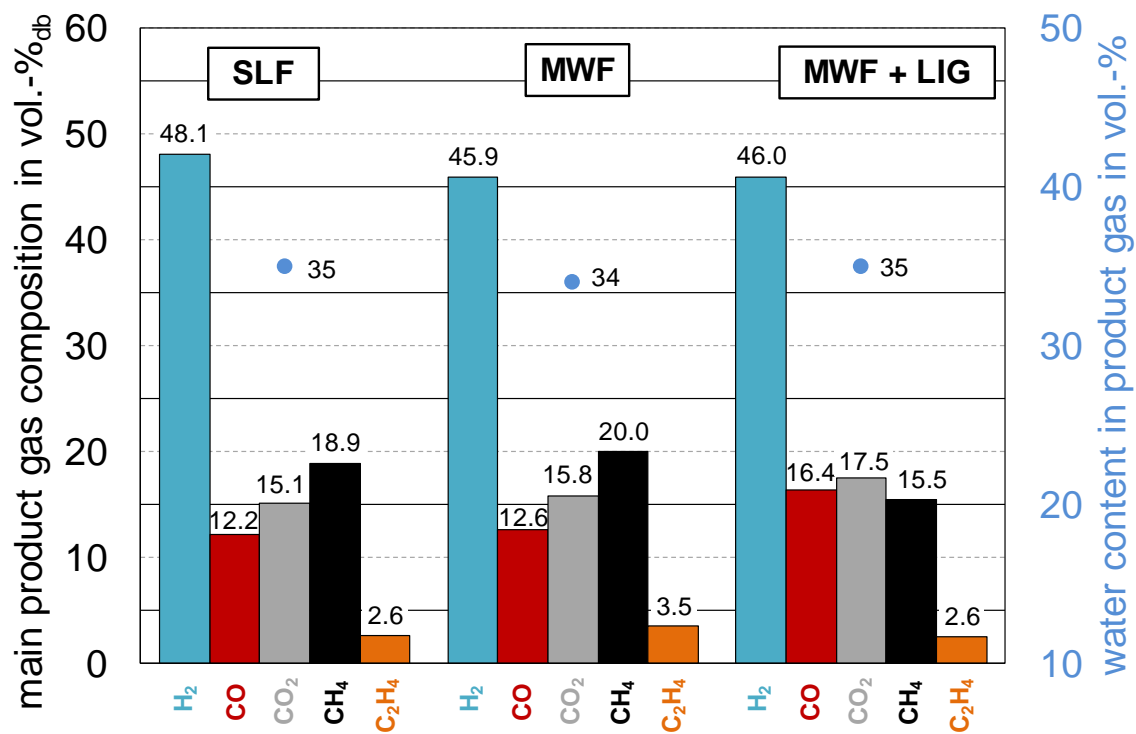

Figure 3. Main product gas compositions

The measured product gas compositions for gasification of SLF and MWF were similar. The $\mathrm{CH}_{4}$ contents in the product gas were higher and the $\mathrm{CO}$ and $\mathrm{CO}_{2}$ lower in comparison to biogenic fuels [9]. This was expected due to the high volatile content of the waste fractions. The product gas composition for the mixture of MWF and LIG shows a different product gas composition in comparison to merely MWF as fuel, due to the increase of fixed carbon in the fuel.

Figure 4 presents the tar contents in the PG as well as calculated tar dew points. The gravimetric tar contents were in a narrow range for the three experiments. As benzene represents the major part of GCMS components, it is visualized separately. A reduction of around $33 \%$ on total GCMS tar content was observed between pure MWF and the mixture of MWF with LIG. This was expected due to the lower amount of volatiles with lignite as fuel blend. Additionally, the share of silica sand in the bed material enabled a higher temperature in the gasification reactor, which generally causes lower GCMS tar contents. However, compared to high-grade wood or lignite as fuel, the presented tar contents and tar dew points show higher values [7].

Figure 5 shows the dust and char contents in the product gas for the gasification test runs with SLF and MWF. The data for the experiment with a mixture of MWF and LIG were not presented due to a clogging that occurred during the dust and char measurement. A higher amount of dust in the product gas was obtained during the gasification of MWF. This was not expected due to the higher amount of ash in the fuel type SLF. The relatively 
$10^{\mathrm{TH}}$ INTERNATIONAL CONFERENCE ON SUSTAINABLE ENERGY AND ENVIRONMENTAL Protection (June $27^{\mathrm{TH}}-30^{\mathrm{TH}}, 2017$, Bled, SLOVEnia), WASTE ENERGY AND

MANAGEMENT

F. Benedikt, J. Christian Schmid \& H. Hofbauer: Waste Gasification with an Advanced 100 kW Dual Fluidized Bed Gasifier

low char contents in both cases are in a typical range for test runs with the advanced pilot plant [7].

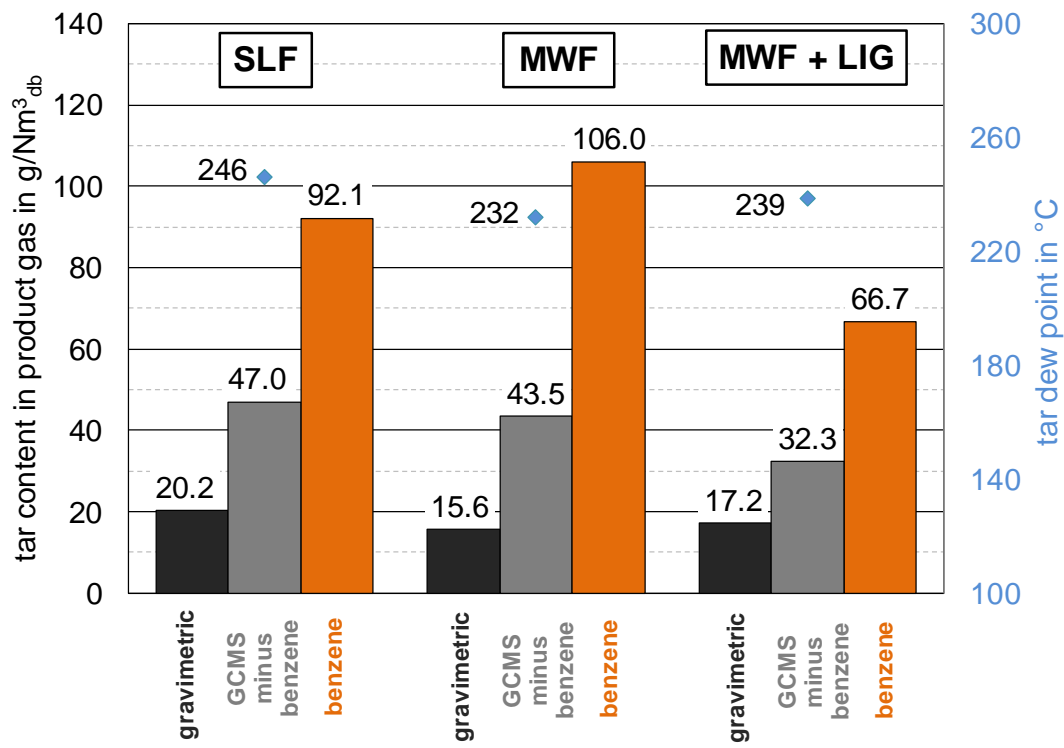

Figure 4. Tar contents and tar dew points of the product gas

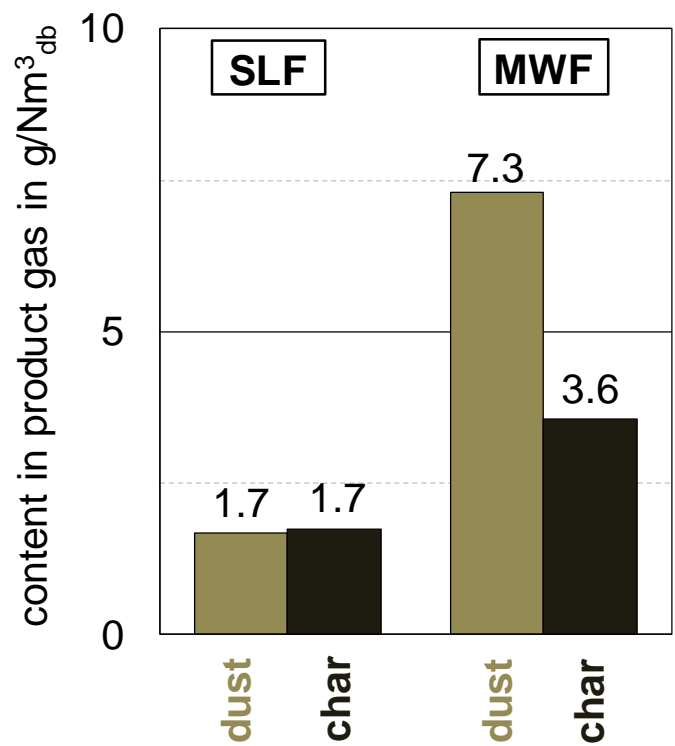

Figure 5. Dust and char contents of the product gas 
$10^{\mathrm{TH}}$ INTERNATIONAL CONFERENCE ON SUSTAINABLE ENERGY AND ENVIRONMENTAL Protection (June $27^{\mathrm{TH}}-30^{\mathrm{TH}}, 2017$, Bled, SLOVEnia), WASte ENERGy AND MANAGEMENT

F. Benedikt, J. Christian Schmid \& H. Hofbauer: Waste Gasification with an Advanced 100 kW Dual Fluidized Bed Gasifier

Table 5 shows the performance indicating key figures for DFB steam gasification.

Table 5. Performance indicating key figures

\begin{tabular}{|l|l|l|l|l|}
\hline Parameter & Unit & SLF & MWF & $\begin{array}{l}\text { MWF } \\
\text { +LIG }\end{array}$ \\
\hline PGY & $\mathrm{Nm}^{3}{ }_{\mathrm{db}} / \mathrm{kg}_{\mathrm{daf}}$ & 2.3 & 2.0 & 2.1 \\
\hline $\mathrm{LHV}_{\mathrm{PG}}$ & $\mathrm{MJ}_{\mathrm{Nm}} \mathrm{db}_{\mathrm{db}}$ & 15.3 & 16.1 & 14.3 \\
\hline $\mathrm{X}_{\mathrm{H} 2 \mathrm{O}}$ & $\mathrm{kg}_{\mathrm{H} 2 \mathrm{O}} / \mathrm{kg}_{\mathrm{H} 2 \mathrm{O}}$ & 0.43 & 0.41 & 0.43 \\
\hline$\eta_{\mathrm{CG}}$ & $\%$ & 92 & 89 & 94 \\
\hline$\eta_{\mathrm{CG}, \mathrm{o}}$ & $\%$ & 71 & 71 & 70 \\
\hline
\end{tabular}

The product gas yield as well as the lower heating value of the product gas show very high values in all cases [7]. Also, the steam-related water conversions as well as cold gas efficiencies were high compared to previous values for the pilot plant operation [8]. Especially, the overall cold gas efficiency of around $70 \%$ shows a great value for all three experiments and offers the basis of an economically promising waste management solution.

\section{$4 \quad$ Conclusion and outlook}

Within this paper, the dual fluidized bed steam gasification with a municipal solid waste fraction and a shredder light fraction was investigated. Additionally, the effect of a fuel blending of $25 \%$ of lignite to the municipal solid waste fraction was evaluated. The waste fractions were gasified with pure calcite as bed material. The mixture of the municipal solid waste fraction and lignite was gasified using a mixture of calcite and silica sand as bed material. Results achieved are summarized as follows:

(i.) Gasification of waste fractions was successfully demonstrated in pilot plant scale. The product gas composition showed relatively high $\mathrm{CH}_{4}$ and low $\mathrm{CO}$ and $\mathrm{CO}_{2}$ contents for the waste fractions as fuel. Thereby, relatively high lower heating values of the product gas were reached: $14-16 \mathrm{MJ} / \mathrm{Nm}_{\mathrm{db}}^{3}$.

(ii.) The gravimetric tar contents of the product gas were in a narrow range of around 15$20 \mathrm{~g} / \mathrm{Nm}^{3} \mathrm{db}$ for all three experiments. The GCMS tar content including benzene was reduced by around 33\% for the fuel blend of municipal solid waste fraction with lignite. (iii.) Despite a high ash content of $12 \mathrm{wt} . \%_{\mathrm{db}}$, the dust content of the product gas for SLF gasification was comparably low.

(iv.) The steam-related water conversion was around 0.4 in all three experiments, which is a high value compared to previous results with biogenic fuels in the pilot plant. This also applies to the cold gas efficiencies (around 90\%) and overall cold gas efficiencies (around 70\%). 
F. Benedikt, J. Christian Schmid \& H. Hofbauer: Waste Gasification with an Advanced 100 kW Dual Fluidized Bed Gasifier

Thereby, the results presented in this paper offer the basis for a sustainable and economically promising waste management solution for the tested municipal solid waste and shredder light fraction. The presentation and discussion of an extensive product gas cleaning, which is necessary for the utilization of the product gas from these fuels, is not part of this paper.

\section{List of abbreviations}

CR

DFB

ECN

GCMS

GR

LHV

LIG

MWF

SLF

temp.

vol.- $\%$

wt.-\% combustion reactor

dual fluidized bed

Energy research Centre of the Netherlands

gas chromatography coupled with mass spectrometry

gasification reactor

lower heating value

lignite

municipal solid waste fraction

shredder light fraction

temperature

volumetric percent

weight percent

\section{List of subscripts}

$\begin{array}{ll}\text { daf } & \text { dry and ash-free } \\ \mathrm{db} & \text { dry basis } \\ \text { th } & \text { thermal }\end{array}$

\section{List of symbols}

\begin{tabular}{|c|c|c|}
\hline $\mathrm{LHV}_{\mathrm{CR}, \text { fuel }}$ & $\begin{array}{l}\text { lower heating value of } \\
\text { fuel into the CR }\end{array}$ & $\mathrm{MJ} / \mathrm{kg}$ \\
\hline $\mathrm{LHV}_{\mathrm{GR}, \text { fuel }}$ & $\begin{array}{l}\text { lower heating value of } \\
\text { fuel into the GR }\end{array}$ & $\mathrm{MJ} / \mathrm{kg}$ \\
\hline $\mathrm{LHV}_{\mathrm{PG}}$ & $\begin{array}{l}\text { lower heating value of PG } \\
\text { on dry basis }\end{array}$ & $\mathrm{MJ} / \mathrm{m}^{3}(25 \mathrm{C}, 1 \mathrm{bar})$ \\
\hline PGY & product gas yield & $\mathrm{Nm}_{\mathrm{db}}^{3} / \mathrm{kg}_{\mathrm{daf}}$ \\
\hline$\dot{\mathrm{m} C, G R, \text { fuel }}$ & $\begin{array}{l}\text { massflow of carbon in the } \\
\text { fuel into the GR }\end{array}$ & $\mathrm{kg}_{\mathrm{C}} / \mathrm{h}$ \\
\hline$\dot{\mathrm{m}}_{\mathrm{CR} \text {,fuel }}$ & $\begin{array}{l}\text { massflow of fuel into the } \\
\text { CR }\end{array}$ & $\mathrm{kg} / \mathrm{h}$ \\
\hline$\dot{\mathrm{m}}_{\mathrm{GR}, \text { fuel }}$ & $\begin{array}{l}\text { massflow of fuel into the } \\
\text { GR }\end{array}$ & $\mathrm{kg} / \mathrm{h}$ \\
\hline$\dot{\mathrm{m}}_{\mathrm{GR}, \text { fuel,daf }}$ & $\begin{array}{l}\text { dry and ash-free massflow } \\
\text { of fuel into the GR }\end{array}$ & $\mathrm{kg} / \mathrm{h}$ \\
\hline$\dot{\mathrm{m}}_{\mathrm{H} 2 \mathrm{O}, \mathrm{GR}, \text { fuel }}$ & $\begin{array}{l}\text { massflow of water in the } \\
\text { fuel into the GR }\end{array}$ & $\mathrm{kg} / \mathrm{h}$ \\
\hline$\dot{\mathrm{m}}_{\mathrm{H} 2 \mathrm{O}, \mathrm{PG}}$ & massflow of water in the & $\mathrm{kg} / \mathrm{h}$ \\
\hline
\end{tabular}


$10^{\mathrm{TH}}$ INTERNATIONAL CONFERENCE ON SUSTAINABLE ENERGY AND ENVIRONMENTAL Protection (June $27^{\mathrm{TH}}-30^{\mathrm{TH}}, 2017$, Bled, SLovenia), WASte ENERGy AND

MANAGEMENT

F. Benedikt, J. Christian Schmid \& H. Hofbauer: Waste Gasification with an Advanced $100 \mathrm{~kW}$ Dual Fluidized Bed Gasifier

\begin{tabular}{|c|c|c|}
\hline \multirow{2}{*}{$\dot{m}_{\text {steam, GR }}$} & \multicolumn{2}{|l|}{ product gas } \\
\hline & $\begin{array}{l}\text { massflow of fluidization } \\
\text { steam into the GR }\end{array}$ & $\mathrm{kg} / \mathrm{h}$ \\
\hline$\dot{Q}_{\text {loss }}$ & $\begin{array}{l}\text { heat losses in the } \\
\text { gasification and } \\
\text { combustion reactor }\end{array}$ & $\mathrm{MJ} / \mathrm{h}($ or $\mathrm{kW})$ \\
\hline$\dot{\mathrm{V}}_{\mathrm{PG}}$ & $\begin{array}{l}\text { volume flow of product } \\
\text { gas on dry basis }\end{array}$ & $\mathrm{m}^{3} / \mathrm{h}(25 \mathrm{C}, 1 \mathrm{bar})$ \\
\hline $\mathrm{X}_{\mathrm{H}_{2} \mathrm{O}}$ & $\begin{array}{l}\text { steam-related water } \\
\text { conversion }\end{array}$ & $\mathrm{kg}_{\mathrm{H} 2 \mathrm{O}} / \mathrm{kg}_{\mathrm{H} 2 \mathrm{O}}$ \\
\hline$\eta_{C G}$ & cold gas efficiency & $\%$ \\
\hline$\eta_{\mathrm{CG}, \mathrm{o}}$ & overall cold gas efficiency & $\%$ \\
\hline$\varphi \mathrm{sC}$ & steam to carbon ratio & $\mathrm{kg}_{\mathrm{H} 2 \mathrm{O}} / \mathrm{kg}_{\mathrm{C}}$ \\
\hline
\end{tabular}

\section{References}

[1] H. Hofbauer, R. Rauch, K. Bosch, R. Koch, and C. Aichernig, "Biomass CHP Plant Güssing - A Success Story," in Expert Meeting on Pyrolysis and Gasification of Biomass and Waste, 2003, pp. 527-536.

[2] V. Wilk and H. Hofbauer, "Analysis of optimization potential in commercial biomass gasification plants using process simulation," Fuel Process. Technol., vol. 141, pp. 138147, Jan. 2016.

[3] F. Kirnbauer, F. Maierhans, M. Kuba, and H. Hofbauer, "State of the art biomass gasification for CHP production - the Ulm plant," Proc. 2nd Int. Conf. Renew. Energy Gas Technol., vol. 1, no. May, pp. 2-5, 2015.

[4] I. Gunnarsson, "The GoBiGas-project - efficient transfer of biomass to bio-SNG of high quality," in Proceedings of the International Seminar on Gasification, 2010, p. 20.

[5] J. C. Schmid, "Development of a novel dual fluidized bed gasification system for increased fuel flexibility," TU Wien, doctoral thesis, 2014.

[6] M. Kuba, F. Havlik, F. Kirnbauer, and H. Hofbauer, "Influence of bed material coatings on the water-gas-shift reaction and steam reforming of toluene as tar model compound of biomass gasification," Biomass and Bioenergy, vol. 89, pp. 40-49, 2016.

[7] F. Benedikt, J. C. Schmid, and H. Hofbauer, "Enhanced Dual Fluidized Bed Gasification Using Calcium Oxide as Bed Material," in 13th Minisymposium Chemical \& Process Engineering, 2017, p. 1.2.1.

[8] M. Kolbitsch, "First Fuel Tests at a Novel $100 \mathrm{kWth}$ Dual Fliuidized Bed Steam Gasification Pilot Plant," TU Wien, doctoral thesis, 2016.

[9] J. C. Schmid, S. Müller, and H. Hofbauer, "First Scientific Results with the Novel Dual Fluidized Bed Gasification Test Facility at TU Wien," in 24th European Biomass Conference and Exhibition, 2016, pp. 2-6.

[10] S. Müller, J. C. Schmid, and H. Hofbauer, "First results with an innovative biomass gasification test plant," 3rd Int. Conf. Renew. Energy Gas Technol., pp. 3-6, 2016.

[11] I. Aigner, C. Pfeifer, and H. Hofbauer, "Co-gasification of coal and wood in a dual fluidized bed gasifier," Fuel, vol. 90, no. 7, pp. 2404-2412, 2011.

[12] ECN, "Thersites the ECN tar dew point site," 2009. [Online]. Available: http://thersites.nl. [Accessed: 15-Sep-2016]. 
$10^{\mathrm{TH}}$ INTERNATIONAL CONFERENCE ON SUSTAINABLE ENERGY AND ENVIRONMENTAL 61 Protection (June $27^{\mathrm{TH}}-30^{\mathrm{TH}}, 2017$, Bled, SLOVENIA), WASTE ENERGY AND

MANAGEMENT

F. Benedikt, J. Christian Schmid \& H. Hofbauer: Waste Gasification with an Advanced 100 kW Dual Fluidized Bed Gasifier

[13] T. Pröll and H. Hofbauer, "Development and Application of a Simulation Tool for Biomass Gasification Based Processe Development and Application of a Simulation Tool for Biomass Gasification Based Processes *," Int. J. Chem. React. Eng., vol. 6, p. Article A89, 2008 
$62 \quad 10^{\text {TH }}$ INTERNATIONAL CONFERENCE ON SUSTAINABLE ENERGY AND ENVIRONMENTAL

Protection (June $27^{\mathrm{TH}}-30^{\mathrm{TH}}, 2017$, BLED, SLOVENiA), WASTE ENERGy AND

MANAGEMENT 
$10^{\mathrm{TH}}$ InTERnational CONFEREnCE ON Sustainable ENERgy AND Environmental Protection (June 27 $7^{\mathrm{TH}}-30^{\mathrm{TH}}, 2017$, BLed, Slovenia), WASTE ENERGY AND MANAGEMENT

J. Krope, A.Ghani Olabi, D. Goričanec \& S. Božičnik

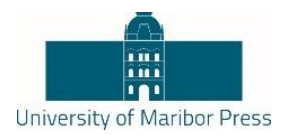

\title{
Performance Analysis of Heat Recovery System from Exhaust Gases of Boiler
}

\author{
MaHmoud Khaleda, MoHamad Ramadan, BAKRi ABED AlHay, Hisham ElHage \& \\ AHMAD HADDAD
}

\begin{abstract}
The present work aims to apply heat recovery concepts to HVAC applications. It particularly uses the energy waste from the exhaust gases of boilers to heat/preheat water. The heat exchanger considered is concentric tube heat exchanger. A thermal modeling of the heat recovery system applied to boilers as well as a corresponding iterative code are developed and presented. Calculations with the code are performed and give magnitude orders of energy saving and management in HVAC applications. It was shown that water can be heated from $20{ }^{\circ} \mathrm{C}(68 \mathrm{~F})$ to up to $100{ }^{\circ} \mathrm{C}(212 \mathrm{~F})$ depending on the mass flow rate.
\end{abstract}

Keywords: • Heat Recovery $\bullet$ Energy Saving $\bullet$ Boiler $\bullet$ Thermal Modelling

- Water Heating •

CORRESPONDENCE ADDRESS: Mahmoud Khaled, Associate Professor, Lebanese International University, School of Engineering, PO Box 146404 Beirut, Lebanon, e-mail: mahmoud.khaled@liu.edu.lb. Mohamad Ramadan, Assistant Professor, Lebanese International University, School of Engineering, PO Box 146404 Beirut, Lebanon, e-mail: mohamad.ramadan@liu.edu.lb. Bakri Abed Alhay, Assistant Professor, Lebanese International University, School of Engineering, PO Box 146404 Beirut, Lebanon, e-mail: bakri.abdulhay@liu.edu.lb. Hisham Elhage, Professor, Lebanese International University, School of Engineering, PO Box 146404 Beirut, Lebanon, e-mail: ahmad.haddad@liu.edu.lb. Ahmad Haddad, Assistant Professor, Lebanese International University, School of Engineering, PO Box 146404 Beirut, Lebanon, e-mail: ahmad.haddad@liu.edu.lb.

https://doi.org/10.18690/978-961-286-063-9.6

ISBN 978-961-286-063-9

(C) 2017 University of Maribor Press

Available at: http://press.um.si. 
$10^{\text {TH }}$ INTERNATIONAL CONFERENCE ON SUSTAINABLE ENERGY AND ENVIRONMENTAL Protection (June $27^{\mathrm{TH}}-30^{\mathrm{TH}}, 2017$, BLED, SLOVENiA), WASTE ENERGY AND MANAGEMENT

M. Khaleda, M. Ramadan, B.i Abed Alhay, H. Elhage \& A. Haddad: Performance Analysis of Heat Recovery System from Exhaust Gases of Boiler

The main concern of science, nowadays, is to find new sources of energy and apply them in life equipment. Recent researches ensure that after 30 year whole world will suffer from the lack of fuel which is the main actual source of energy [1]. Wind, River, Solar, Sea waves, even nuclear are different forms of renewable energy which scientists is trying to benefit from [2-4], in many sectors, by generating electricity and other forms of energy. These renewable energies as well as heat recovery concepts [5-6] are actually the main means towards the reduction of fuel consumption and carbon dioxide emissions.

Heat recovery is defined as the capture of heat contained in fluids or gases of systems and its use in production of other forms of energy and that otherwise would be lost. Depending on the system in which hot fluids or gases are contained, heat recovery has different applications: internal combustion engines, heat pumps, chillers, power generators, chimneys and shower water [6]. On the other hand and depending on the final form of energy captured, the heat recovery is of different types: heat exchanger systems when thermal energy output is required and thermodynamic heat recovery system when electrical power output is desired. Heat exchanger systems are systems based on transferring heat from high temperature stream (exhaust in the present case) into low temperature stream (water pipe in this case) [6].

On the other hand, Heating, Ventilating and Air Conditioning HVAC systems has changed from being luxury to essential need for people and thus involve many energy components which need to be more and more managed. In this context, the present work suggests a new design that permits to couple between the two energy domains described above: energy recovery and HVAC. It particularly uses the energy waste from the exhaust gases of boilers to heat/preheat water. For this purpose, a thermal modeling of the recovery system is presented and iterative procedure is described. The heat exchanger considered is concentric tube heat exchanger. A parametric analysis testing the effect of the exchanger geometry (inlet and outlet diameters) is also performed.

\section{Thermal modeling and iterative procedure}

The heat exchanger considered in the present study is counter flow concentric tube heat exchanger with inner diameter $D_{i}$, outer diameter $D_{o}$ and length $L$. In the thermal modeling presented below and for presentation clarity, the exhaust gases of the boiler are considered flowing in the inner tube of the exchanger and water flowing in the annulus of the exchanger. Later in the calculations, the configurations can be inversed and the governing equations inversed accordingly. In this type of exchanger and neglecting the heat transfer between water in the annulus and the ambient air, the energy balance can be written as [7]: 
M. Khaleda, M. Ramadan, B.i Abed Alhay, H. Elhage \& A. Haddad: Performance Analysis of Heat Recovery System from Exhaust Gases of Boiler

$$
\begin{aligned}
& \dot{m}_{w} C_{p, w}\left(T_{w, \text { out }}-T_{w, \text { in }}\right)=\dot{m}_{g} C_{p, g}\left(T_{i n, \text { gas }}-T_{\text {out }, \text { gas }}\right) \\
& =U A \Delta T_{\mathrm{ln}}
\end{aligned}
$$

Where:

$\dot{m}_{w}$ and $\dot{m}_{g}$ are respectively the water and gas mass flow rates, $C_{p, w}$ and $C_{p, g}$ are respectively the water and gas specific heats, $T_{w, \text { in }}$ and $T_{g, \text { in }}$ are respectively the water and gas inlet temperatures, $T_{w, \text { out }}$ and $T_{g, \text { out }}$ are respectively the water and gas outlet temperatures, $U$ the overall heat transfer coefficient between the two fluids streams, $A$ the area of heat transfer between the two fluids, and $\Delta T_{\text {ln }}$ the logarithmic mean temperature difference between the two fluids calculated from:

$$
\Delta T_{\mathrm{ln}}=\frac{\left(T_{g, \text { out }}-T_{w, \text { in }}\right)-\left(T_{g, \text { in }}-T_{w, \text { out }}\right)}{\ln \left[\frac{\left(T_{g, \text { out }}-T_{w, \text { in }}\right)}{\left(T_{g, \text { in }}-T_{w, \text { out }}\right)}\right]}
$$

In most heat exchanger applications, a thin wall of large conductivity is generally used between the two fluid streams and then the overall heat transfer coefficient and the heat transfer area can be calculated from:

$$
\begin{aligned}
& U=\frac{1}{\frac{1}{h_{w}}+\frac{1}{h_{g}}} \\
& A=\pi D_{i} L
\end{aligned}
$$

Where $h_{w}$ and $h_{g}$ are the convective heat transfer coefficients of respectively the water and gas flows calculated from heat transfer correlations found in [7].

To calculate the heat transfer rate that can be recovered from the exhaust gas, one of the outlet temperatures should be calculated. To proceed, Equations (1) to (4) are rearranged in order to obtain one equation with only one unknown the water outlet temperature $T_{w, \text { out }}$ : 
M. Khaleda, M. Ramadan, B.i Abed Alhay, H. Elhage \& A. Haddad: Performance Analysis of Heat Recovery System from Exhaust Gases of Boiler

$$
\begin{aligned}
& \dot{m}_{w} C_{p, w}\left(T_{w, \text { out }}-T_{w, \text { in }}\right)= \\
& \left.U A \frac{\left[T_{g, \text { in }}-\frac{\dot{m}_{w} C_{p, w}}{\dot{m}_{g} C_{p, g}}\left(T_{w, \text { out }}-T_{w, \text { in }}\right)-T_{w, \text { in }}\right]-\left(T_{g, \text { in }}-T_{w, \text { out }}\right)}{\ln \left[\frac{\left(T_{g, \text { in }}-\frac{\dot{m}_{w} C_{p, w}}{\dot{m}_{g} C_{p, g}}\left(T_{w, \text { out }}-T_{w, \text { in }}\right)-T_{w, \text { in }}\right)}{\left(T_{g, \text { in }}-T_{w, \text { out }}\right)}\right]}\right]
\end{aligned}
$$

Equation (5) is solved by iteration to obtain the water outlet temperature $T_{\text {out }, w}$ for given flow rates, inlet temperatures and specific heats of water and gas. Then, the heat rate recovered from exhaust gases can be determined:

$$
P_{\text {exchanger }}=\dot{m}_{w} C_{p, w}\left(T_{w, \text { out }}-T_{w, \text { in }}\right)
$$

Now, to calculate the gas flow rate $\dot{m}_{g}$ and inlet temperature $T_{g, \text { in }}$ that are input to the heat exchanger calculations presented above, the boiler side is considered. The efficiency of a boiler is defined as the ratio of the heating load provided to the space $\dot{Q}_{\text {heating }}$ (and calculated in HVAC designs) and the heat of combustion $\dot{Q}_{\text {combustion }}$ [8]:

$\eta_{b}=\frac{\dot{Q}_{\text {heating }}}{\dot{Q}_{\text {combustion }}}$

The difference between the heating load $\dot{Q}_{\text {heating }}$ and $\dot{Q}_{\text {combustion is lost in the exhaust }}$ gases and then the energy rate contained in the exhaust gases is:

$$
\dot{Q}_{\text {ex }}=\dot{Q}_{\text {combustion }}-\dot{Q}_{\text {heating }}
$$

Combining equations (7) and (8) yields to:

$$
\dot{Q}_{e x}=\left(\frac{1-\eta_{b}}{\eta_{b}}\right) \dot{Q}_{\text {heating }}
$$


M. Khaleda, M. Ramadan, B.i Abed Alhay, H. Elhage \& A. Haddad: Performance Analysis of Heat Recovery System from Exhaust Gases of Boiler

At the same time, the energy rate of the exhaust gases can be written as:

$$
\dot{Q}_{e x}=\dot{m}_{g} C_{p, g}\left(T_{i n, g}-T_{a m b}\right)
$$

Where $T_{a m b}$ is the ambient temperature.

The fuel (Diesel) flow rate can be calculated from:

$$
\dot{m}_{f}=\frac{\dot{Q}_{\text {combustion }}}{q_{c}}=\frac{\dot{Q}_{\text {heating }}}{\eta_{b} \cdot q_{c}}
$$

Where $q_{c}$ is the heat of combustion of the fuel (Diesel).

Noting $A_{a f}$ the air to fuel ratio, the gas mass flow rate can be written as:

$$
\dot{m}_{g}=\left(A_{a f}+1\right) \dot{m}_{f}=\frac{\left(A_{a f}+1\right) \dot{Q}_{\text {heating }}}{\eta_{b} \cdot q_{c}}
$$

Combining equations (9), (10) and (12), one can write for the gases inlet temperature:

$T_{g, i n}=T_{a m b}+\frac{\left(1-\eta_{b}\right) q_{c}}{\left(A_{a f}+1\right) C_{p, g}}$

The operational mode of the code developed for the present calculations consists on an iterative procedure manipulating the different equations presented in the thermal modelling presented above in order to have a set of input parameters and calculating the main output: the heat exchanger performance. Figure 1 shows a schematic of the overall scheme of the code.

The code solves the problem iteratively using a partitioned algorithm allowing coupling the two physical problems: cooling the condenser by the air and heating the water by the heated air. The inputs of the developed code are: the operational parameters of the HVAC system, the characteristics of the heat exchanger, and the physical properties of air and water.

Figure 1-b shows schematically the operational mode of the code. In the first part of the solver the energy balance equation applied to the boiler side is solved, which gives the value of the exhaust gases mass flow rate and temperature. In the second part the energy 
$10^{\mathrm{TH}}$ INTERNATIONAL CONFERENCE ON SUSTAINABLE ENERGY AND ENVIRONMENTAL Protection (June $27^{\mathrm{TH}}-30^{\mathrm{TH}}, 2017$, Bled, SLOVENIA), WASTE ENERGY AND MANAGEMENT

M. Khaleda, M. Ramadan, B.i Abed Alhay, H. Elhage \& A. Haddad: Performance Analysis of Heat Recovery System from Exhaust Gases of Boiler

balance equation applied to the heat exchanger is solved. The temperature and mass flow rate obtained from the first part are input for the heat exchanger calculation part, whereas the temperature of the water is the inlet cold temperature. The solver iterates until reaching a convergence.

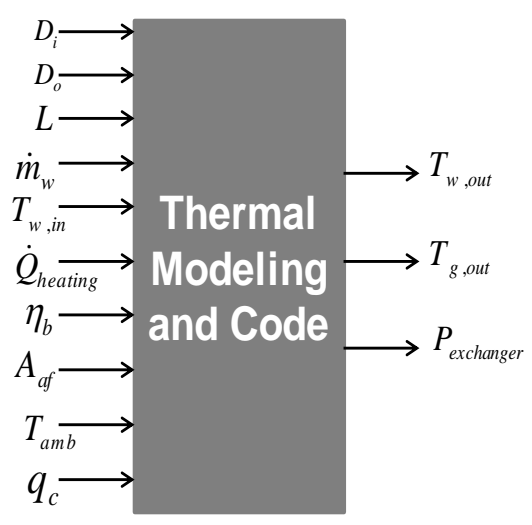

(a)

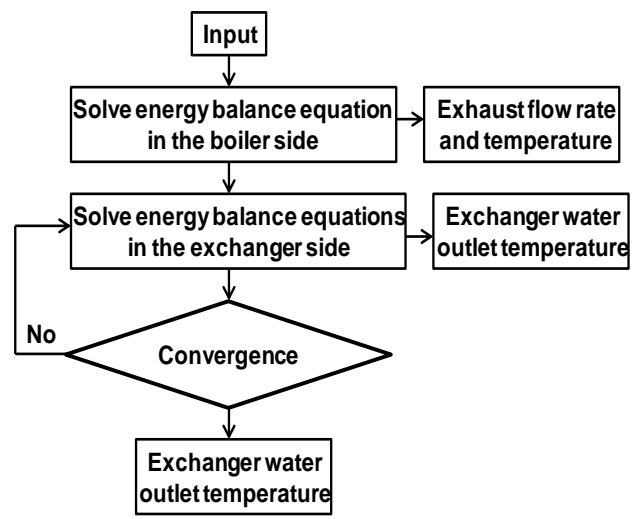

(b)

Figure 1. Schematic of the (a) overall scheme and (b) operational mode of the code developed.

\section{$3 \quad$ Results and Analysis}

The thermal modelling presented in the previous section is employed to perform parametric analysis on the thermal performance of the boiler heat recovery concept proposed. The performance of the heat exchanger of the system is explored when the geometry of the exchanger is varied. A counter-flow concentric tube heat exchanger of three meters length is used to heat water by the exhaust gases is considered. The water inlet temperature is fixed at $20^{\circ} \mathrm{C}(68 \mathrm{~F})$. The heating load is considered equal to $100 \mathrm{~kW}$ (341 $200 \mathrm{Btu} / \mathrm{hr}$ ) (magnitude orders for an apartment of 5 to 8 people) and the boiler efficiency is considered equal to 0.8 . The ambient temperature is equal to $20{ }^{\circ} \mathrm{C}(68 \mathrm{~F})$ and the air-to-fuel ratio is equal to 15 . The exhaust gas is considered flowing in the inner tube and water in the annulus. The three geometrical configurations tested are detailed in Table 1.

Calculations are performed by varying the water flow rate from $0.02 \mathrm{~kg} / \mathrm{s}$ to $0.5 \mathrm{~kg} / \mathrm{s}$ with a step of $0.02 \mathrm{~kg} / \mathrm{s}$. Figure 2 shows the variation of the water outlet temperature and waste power (heat rate) recovered in terms of the water flow rate and for configurations 1 to 3 . 
$10^{\text {TH }}$ INTERNATIONAL CONFERENCE ON SUSTAINABLE ENERGY AND ENVIRONMENTAL Protection (June $27^{\mathrm{TH}}-30^{\mathrm{TH}}, 2017$, Bled, Slovenia), WASte ENERGy AND

MANAGEMENT

M. Khaleda, M. Ramadan, B.i Abed Alhay, H. Elhage \& A. Haddad: Performance Analysis of Heat Recovery System from Exhaust Gases of Boiler

Table 1. Details of the different geometrical configurations tested.

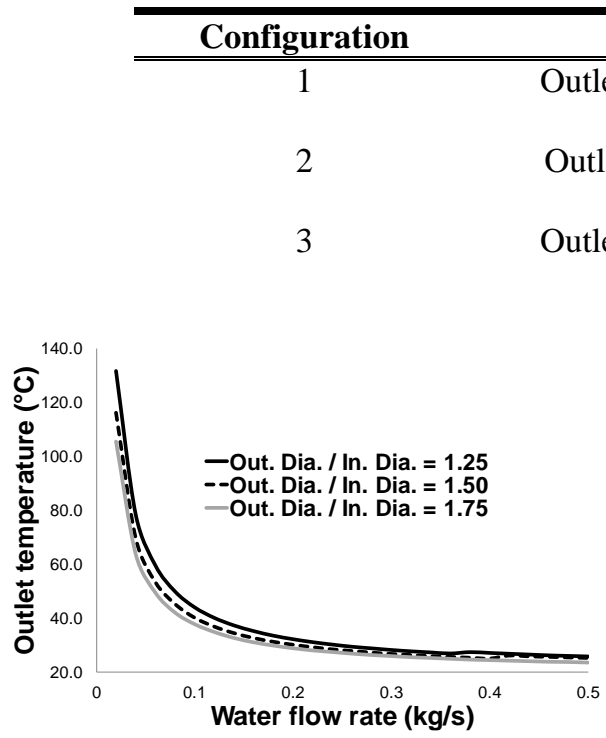

\section{Diameters}

Outlet to inlet diameter ratio $=1.25$

Inner diameter $=0.1 \mathrm{~m}$

Outlet to inlet diameter ratio $=1.5$

Inner diameter $=0.1 \mathrm{~m}$

Outlet to inlet diameter ratio $=1.75$

Inner diameter $=0.1 \mathrm{~m}$ (a)

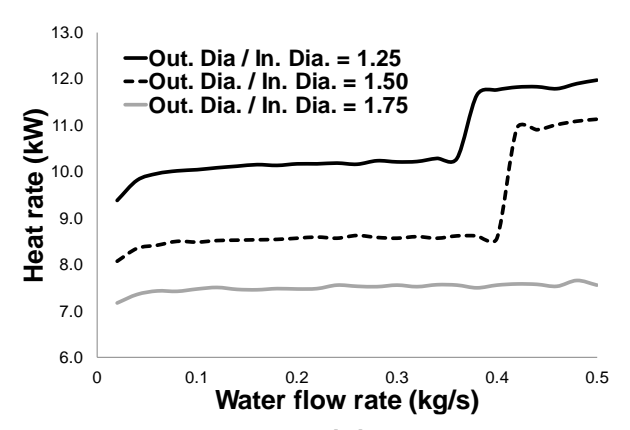

(b)

Figure 2. Variation of (a) the water outlet temperature and (b) waste heat recovered in function of the water mass flow rate for different configurations.

From Figure 2-a, it can be shown that the water outlet temperature decreases exponentially with the water flow rate and decreases with the outer diameter for a fixed inner diameter. As illustration for an outer to inner diameter ratio of 1.25 , by increasing the water flow rate from $0.02 \mathrm{~kg} / \mathrm{s}$ to $0.5 \mathrm{~kg} / \mathrm{s}$ the water outlet temperature decreases from $131.6{ }^{\circ} \mathrm{C}$ to $25.7^{\circ} \mathrm{C}$. For outer/inner diameter ratios of 1.5 and 1.75 , the water outlet temperature decreases from $116.1{ }^{\circ} \mathrm{C}$ to $25.3{ }^{\circ} \mathrm{C}$ and from $105.4{ }^{\circ} \mathrm{C}$ to $23.6{ }^{\circ} \mathrm{C}$ respectively. It should be noted that actually water temperature greater than $100^{\circ} \mathrm{C}$ does not exist and this mean that water will evaporate before travelling the entire length of the exchanger. Values of water temperature higher than $100{ }^{\circ} \mathrm{C}$ will be kept in the calculations only to give magnitude orders on waste heats that can be recovered.

From Figure 2-b, it can be shown that for an outer/inner diameter ratio of 1.75 the heat rate is almost invariant equal to $7.5 \mathrm{~kW}$. For the diameter ratios of 1.25 and 1.5 , sudden increases in the heat rate exchanged occur at given water flow rates. As illustration for an outer/inner diameter ratio of 1.25 , the heat rate is almost constant around $10 \mathrm{~kW}$ up to a water flow rate of $0.36 \mathrm{~kg} / \mathrm{s}$ from which it increases suddenly to $11.7 \mathrm{~kW}$ and continue its increase with an exponential manner. The same trends are noted for the diameter ratio of 1.5 but with different magnitudes and transition for a water flow rate of $0.4 \mathrm{~kg} / \mathrm{s}$. These sudden increases are due to the transition from laminar to turbulent regimes that occur at constant water flow rate and because of the change of the geometry. To illustrate Figure 
$10^{\text {TH }}$ INTERNATIONAL CONFERENCE ON SUSTAINABLE ENERGy AND ENVIRONMENTAL Protection (June $27^{\mathrm{TH}}-30^{\mathrm{TH}}, 2017$, Bled, SLOVEnia), WASte ENERGy AND MANAGEMENT

M. Khaleda, M. Ramadan, B.i Abed Alhay, H. Elhage \& A. Haddad: Performance Analysis of Heat Recovery System from Exhaust Gases of Boiler

3 shows the variation of the Reynolds number of water in terms of the water flow rate for the three configurations tested above. On this figure, the limit of Reynolds number of 2300 for transition to turbulent regime is shown also.

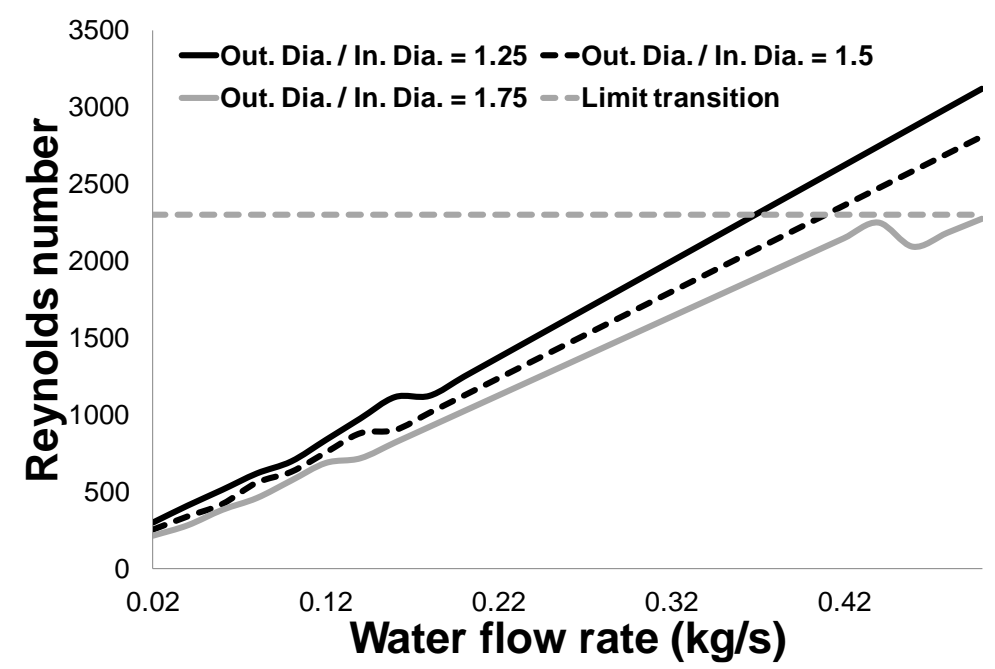

Figure 3. Variation of the Water Reynolds number in terms of the water flow rate for the first three configurations tested.

It can be shown that by varying the water flow rate from $0.02 \mathrm{~kg} / \mathrm{s}$ to $0.5 \mathrm{~kg} / \mathrm{s}$ for an outer/inner diameter ratio of 1.75 , the flow remains laminar with the Reynolds number varying from 212 to 2271 . For an outer/inner diameter ratio of 1.5 , the Reynolds number varies from 252 to 2808 with 2300 reached at a water flow rate around $0.4 \mathrm{~kg} / \mathrm{s}$. For an outer/inner diameter ratio of 1.25 , the Reynolds number increases from 300 to 3120 with 2300 reached at a water flow rate around $0.36 \mathrm{~kg} / \mathrm{s}$. It should be noted that the inner Reynolds number of gases is invariant between the three configurations and with the water flow rate and equals 17 628. This high Reynolds number induces high convective coefficient of the gases flow. In the three configurations and before transition to turbulence, when the water flow rate increases the water convective coefficient increases with magnitude orders remaining negligible compared to the gases convective coefficient yielding to a negligible effect on the overall heat transfer coefficient of equation (3) and then on the rate of waste heat recovered. For the outer/inner diameter ratios of 1.25 and 1.5 , when transition occurs the water convective coefficient increases to a limit that it becomes no longer negligible compared to the gases convective coefficient and its increase induces an increase in the overall heat transfer coefficient and then in the rate of waste heat recovered.

From a practical point of view, the results exposed above can be shown in the form of recommendations. One should use an outer diameter of outer flow the most closer to the inner diameter in order to enhance the heat recovery occurring. By decreasing the outer 
M. Khaleda, M. Ramadan, B.i Abed Alhay, H. Elhage \& A. Haddad: Performance Analysis of Heat Recovery System from Exhaust Gases of Boiler

diameter for a fixed inner diameter, one is fastening the transition to turbulence and thus enhancing the heat transfer rate for the same quantity of water flowing. At the same time for each geometrical configuration, the mass flow rate corresponding to the transition should be calculated preliminary and flow rates higher than this value are recommended.

\section{Conclusion}

The present work concerns a parametric analysis of recovering heat from boiler exhaust through the use of counter flow concentric tube heat exchanger. Different geometrical configurations are tested. A case of a $100 \mathrm{~kW}$ (341 $200 \mathrm{Btu} / \mathrm{hr}$ ) boiler is considered.

It was shown that water temperatures up to $100{ }^{\circ} \mathrm{C}$ can be obtained depending on the mass flow rate. It is more recommended to have the outer diameter the most closely possible to the constant inner diameter.

\section{References}

[1] L.S. Shi, and M. Yit Lin Chew, "A review on sustainable design of renewable energy systems", Renewable and Sustainable Energy Review, Vol 16, pp. 192-207, 2012.

[2] K.H Solangi, M.R Islam, R. Saidur, N.A. Rahim, and H. Fayaz, "A review on global solar energy policy”, Renewable and Sustainable Energy Review, Vol 15, pp. 2149-2163, 2011.

[3] G.M. Joselin Herbert,S. Iniyan, E. Sreevalsan, and S. Rajapandian, "A review of wind energy technologies” Renewable and Sustainable Energy Review, Vol 11, pp. 1117-1145, 2007.

[4] I. Lopez, J. Andreu, S. Ceballos, I. Martinez de Alegria, and I. Kortabarria, "Review of wave energy technologies and the necessary power-equipment", Renewable and Sustainable Energy Review, Vol 27, pp. 413-434, 2013.

[5] N.L. Panwar, S.C. Kaushik, and S. Kothari, "Role of renewable energy sources in environmental protection: A review", Renewable and Sustainable Energy Review, Vol 15, pp. 1753-1766, 2011.

[6] A. Mardiana-Idayu, and S.B. Riffat, "Review on heat recovery technologies for building applications" Renewable and Sustainable Energy Review, Vol 16, pp. 1241-1255, 2012.

[7] Incorpera, F.P. and DeWitt, D.P. 2007. Fundamentals of heat and mass transfer. Sixth Edition. John Wiley \& Sons.

[8] J. Bujak, "Mathematical modeling of a steam boiler room to research thermal efficiency", Energy, Vol 33 (12), pp. 1779-1787, 2008. 
$7210^{\text {TH }}$ INTERNATIONAL CONFERENCE ON SUSTAINABLE ENERGY AND ENVIRONMENTAL

Protection (June $27^{\mathrm{TH}}-30^{\mathrm{TH}}, 2017$, Bled, SLOVENiA), WAste ENERGY AND

MANAGEMENT 
$10^{\mathrm{TH}}$ InTERnational CONFERENCE ON Sustainable ENERgy AND

ENVIRONMENTAL PRotection (June $27^{\mathrm{TH}}-30^{\mathrm{TH}}$, 2017, Bled, Slovenia), WASTE ENERGY AND MANAGEMENT

J. Krope, A.Ghani Olabi, D. Goričanec \& S. Božičnik

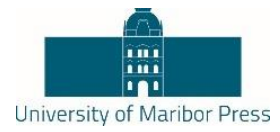

\title{
Protection Of TEG Module at High Temperature Transient Boundary Condition Using Phase Change Materials, an Experimental Investigation
}

\author{
Saeed Ahmadi Atouei, Alireza ReZaniakolaei, Ali Akbar Ranjbar \& LASSE \\ AISTRUP ROSENDAHL
}

\begin{abstract}
Although every thermoelectric module (TEM) has a certain optimum temperature condition, however keeping the constant temperature boundary conditions is not practical in most applications. When a thermoelectric generator works at lower temperature than its optimum condition, reaching the maximum efficiency is not promising. In addition, working at higher temperature than the optimal operation temperature not only reduces the performance of the system but also it may damage the module. In this study, in order to control the temperature of the hot side of the thermoelectric module, some different phase change materials (PCM) in an aluminium box are placed between heat source and the thermoelectric module. The results show when the input heat flux is high, a fraction of the thermal energy is saved in the PCM during the melting process, and when the heat source is off, the saved energy in the PCM release slowly, causing a more stable electrical energy production by the TEM and lower the effect of the heat source temperature fluctuations. This study also shows by design of a proper geometry and selection of efficient PCMs, not only the high temperature pulse by the heat source is damped, also more stable electricity for longer time is possible when the heat source is off.
\end{abstract}

Keywords: • thermoelectric generator $\bullet$ phase change materials $\bullet$ transient condition • experimental study •

CorRespondence AdDress: Saeed Ahmadi Atouei, Ph.D Student, Babol University of Technology, Department of Mechanical Engineering, Shariati Av., Babol, Mazandaran, Iran, email: s.a.atouei@stu.nit.ac.ir. Alireza Rezaniakolaei, Assistant Professor, Aalborg University, Department of Energy Technology, 9220 Aalborg, Denmark, e-mail: alr@et.aau.dk. Ali Akbar Ranjbar, Professor, Babol University of Technology, Department of Mechanical Engineering, Shariati Av., Babol, Mazandaran, Iran, e-mail: ranjbar@nit.ac.ir. Lasse Aistrup Rosendahl, Professor, Aalborg university, Department of Energy Technology, 9220 Aalborg, Denmark, e-mail: lar@et.aau.dk. 
$10^{\text {TH }}$ INTERNATIONAL CONFERENCE ON SUSTAINABLE ENERGY AND ENVIRONMENTAL Protection (June $27^{\mathrm{TH}}-30^{\mathrm{TH}}, 2017$, Bled, SLOVEnia), WASte ENERGy AND MANAGEMENT

S. Ahmadi Atouei, A. Rezaniakolaei, A.Akbar Ranjbar \& L. Aistrup Rosendahl: Protection Of TEG Module at High Temperature Transient Boundary Condition Using Phase Change Materials, an Experimental Investigation

\section{Introduction}

Thermoelectric modules (TEMs) are solid state devices that directly convert heat into electrical energy by temperature difference between hot side and cold side of the TEG module [1].Practically, in the most applications of thermoelectric generators, the hot side temperature of the TEG is not stable. As the temperature stability directly affects the characteristics of the whole system, the performance of TEG is sensitive to the temperature on both sides of the TEMs. On the other hand, an unanticipated rise in temperature more than practical operating temperature could make failure in the TEMs [2].To stabilize the fluctuations of heat input to a TEM at transient boundary conditions, and to protect it from large temperature fluctuations, phase change materials (PCM) are proposed and investigated by various researches $[3,4]$. PCMs can store a large amount of energy as latent heat at a constant phase transition temperature [5]. Applying phase change materials in the thermal system between heat source and TEM, not only can protect the TEM and stabilize the temperature fluctuations, moreover it can save some of the thermal energy at high temperature conditions and release it when the heat source apply lower heat or is off.

In this study, two different types of PCMs with different properties are placed in an aluminium box and installed between the heat source and the TEM. Figure 1, shows schematic of the thermal system. Three different experiments have been tested. Two of the setups includes PCM box, while the results are compared with a thermal system without a PCM box. 
$10^{\mathrm{TH}}$ INTERNATIONAL CONFERENCE ON SUSTAINABLE ENERGY AND ENVIRONMENTAL Protection (June $27^{\mathrm{TH}}-30^{\mathrm{TH}}, 2017$, Bled, SLOVEnia), WASte ENERgy AND

MANAGEMENT

S. Ahmadi Atouei, A. Rezaniakolaei, A.Akbar Ranjbar \& L. Aistrup Rosendahl: Protection Of TEG Module at High Temperature Transient Boundary Condition Using Phase Change Materials, an Experimental Investigation
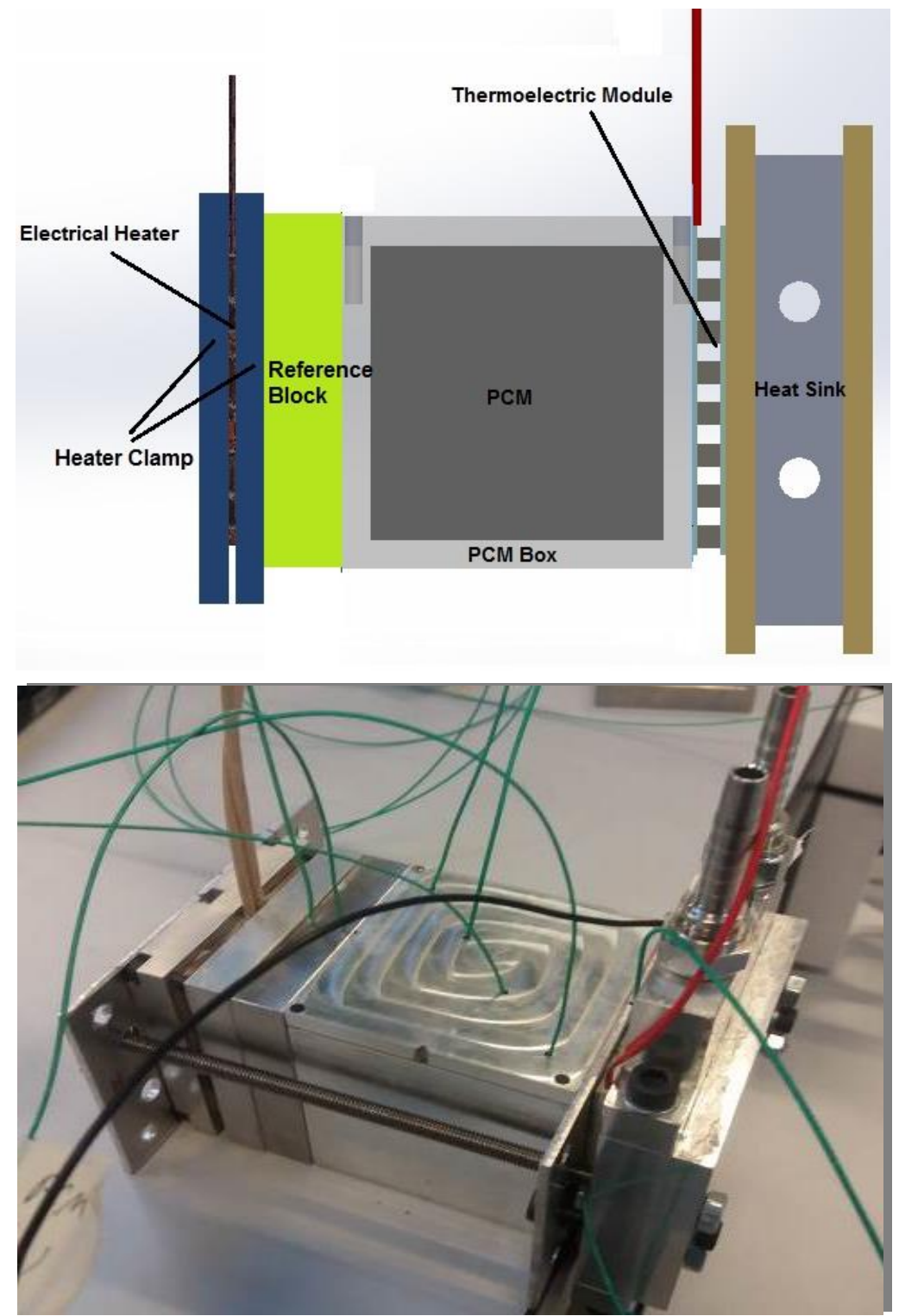

Figure 1. The schematic of the thermal system 
$10^{\mathrm{TH}}$ INTERNATIONAL CONFERENCE ON SUSTAINABLE ENERGY AND ENVIRONMENTAL Protection (June $27^{\mathrm{TH}}-30^{\mathrm{TH}}, 2017$, Bled, SLOVEnia), WASte ENERGy AND MANAGEMENT

S. Ahmadi Atouei, A. Rezaniakolaei, A.Akbar Ranjbar \& L. Aistrup Rosendahl: Protection Of TEG Module at High Temperature Transient Boundary Condition Using Phase Change Materials, an Experimental Investigation

\section{$2 \quad$ Experimental setup}

An experimental thermoelectric generator system including TEM, an aluminium box and a water cooling heat sink has been tested for two different PCMs. The heater is mechanically clamped between two aluminium plates with dimension of $60 \mathrm{~mm} \times 60$ $\mathrm{mm} \times 10 \mathrm{~mm}$. A block of stainless steel-grade 316 with dimension of $60 \mathrm{~mm} \times 60 \mathrm{~mm} \times 12$ $\mathrm{mm}$ including two thermocouples were installed between the heater and PCM box to measure heat flux received by the PCM. The thickness of the aluminium box was $5 \mathrm{~mm}$ with capacity of $125 \mathrm{~cm}^{3}$. The TEM with dimensions of $56 \mathrm{~mm} \times 56 \mathrm{~mm}$ is used for generating the electrical power from the heat source. Two PCMs with different melting temperature are used in this study. Table 1 shows the properties of the materials. All surfaces of the setup exposed to the ambient are thermally insulated. The flow rate and inlet temperature in the heat sink is constant during all the tests. K-type thermocouples were used for temperature measurement. These thermocouples have a measurement range up to $1250{ }^{\circ} \mathrm{C}$ with error of $0.75 \%$. A data acquisition unit (manufacturer: KEYSIGHT TECHNOLOGIES, Part No: 34972A) was used to record the measurements data of voltage, current and temperatures.

Table 1. Properties of phase change materials $[4,6]$

\begin{tabular}{|c|c|c|}
\hline РСМ Туре & PCM133 & PCM164 \\
\hline PCM Name & Urea & d-Mannitol \\
\hline $\begin{array}{l}\text { Phase Change } \\
\text { Temperature }\left[{ }^{\circ} \mathrm{C}\right]\end{array}$ & 133 & 164-168 \\
\hline Density $\left[\mathrm{kg} / \mathrm{m}^{3}\right]$ & 1320 & 1490 \\
\hline $\begin{array}{l}\text { Latent Heat } \\
\text { Capacity }[\mathrm{kJ} / \mathrm{kg}]\end{array}$ & 250 & 294-341 \\
\hline $\begin{array}{lr}\text { Specific } & \text { Heat } \\
\text { Capacity } & {[\mathrm{kJ} / \mathrm{kg}} \\
\mathrm{K}] & \end{array}$ & $1.8(\mathrm{~s})-2.11(\mathrm{l})$ & $1.31(\mathrm{~s})-2.36(\mathrm{l})$ \\
\hline $\begin{array}{l}\text { Thermal } \\
\text { Conductivity } \\
{[\mathrm{W} / \mathrm{m} \mathrm{K}]}\end{array}$ & $0.8(\mathrm{~s})-0.6(1)$ & $0.19(\mathrm{~s})-0.11(\mathrm{l})$ \\
\hline Type & $\begin{array}{c}\text { organic } \\
\text { compounds }\end{array}$ & Sugar alcohol \\
\hline
\end{tabular}

\section{$3 \quad$ Experimental procedure}

This study aims investigation of application of PCMs for TEMs from failure in high temperature fluctuations over practical operation conditions. To create a transient condition, the electrical heater was switched off and switched on every 5 minutes for 3 times. The PCM melted at nearly constant temperature keeping the PCM box under critical temperature. This behaviour of the PCM reasons fluctuation of the boundary 
$10^{\mathrm{TH}}$ INTERNATIONAL CONFERENCE ON SUSTAINABLE ENERGY AND ENVIRONMENTAL Protection (June $27^{\mathrm{TH}}-30^{\mathrm{TH}}, 2017$, Bled, SLOVEnia), WASte ENERgy AND

MANAGEMENT

S. Ahmadi Atouei, A. Rezaniakolaei, A.Akbar Ranjbar \& L. Aistrup Rosendahl: Protection Of TEG Module at High Temperature Transient Boundary Condition Using Phase Change Materials, an Experimental Investigation

conditions has less effect on the TEM. As the temperature difference is created between the hot and cold sides of the TEM, electricity voltage is generated. Three different testes had been investigated at this study. At first, PCM133 was tested. The results were recorded for about 1 hour after switching off of the electrical heater. Then, the results were generated for PCM164. Finally, the PCM box was removed from the setup and the reference block was connected directly to the hot side of the TEM. For all the tests, $480 \mathrm{~W}$ electrical power was imposed to the electrical heater and, the inlet temperature and coolant flow rate in the heat sink were kept constant.

\section{$4 \quad$ Experimental results}

Figure 2 shows the hot side temperature variation of the TEM for the all three tests. As shown in the Figure 2, the effect of using PCM is clearly visible. Results show that using both type of the PCMs could damp most of temperature fluctuations and reduce the pick of temperature in the TEG module. It also shows PCM164 could save more thermal energy when heater is on and release more energy in the longer time after removing the external thermal energy from the heater because of the thermal properties of the PCMs. Furthermore, the rage of temperature fluctuation for the case of without using PCM box is much greater than the cases with using PCMs. Experimental results show that the maximum temperature of the TEM receives about $300^{\circ} \mathrm{C}$ that it is a critical temperature for most BiTe thermoelectric module, and makes the BiTe based TEMs inefficient.

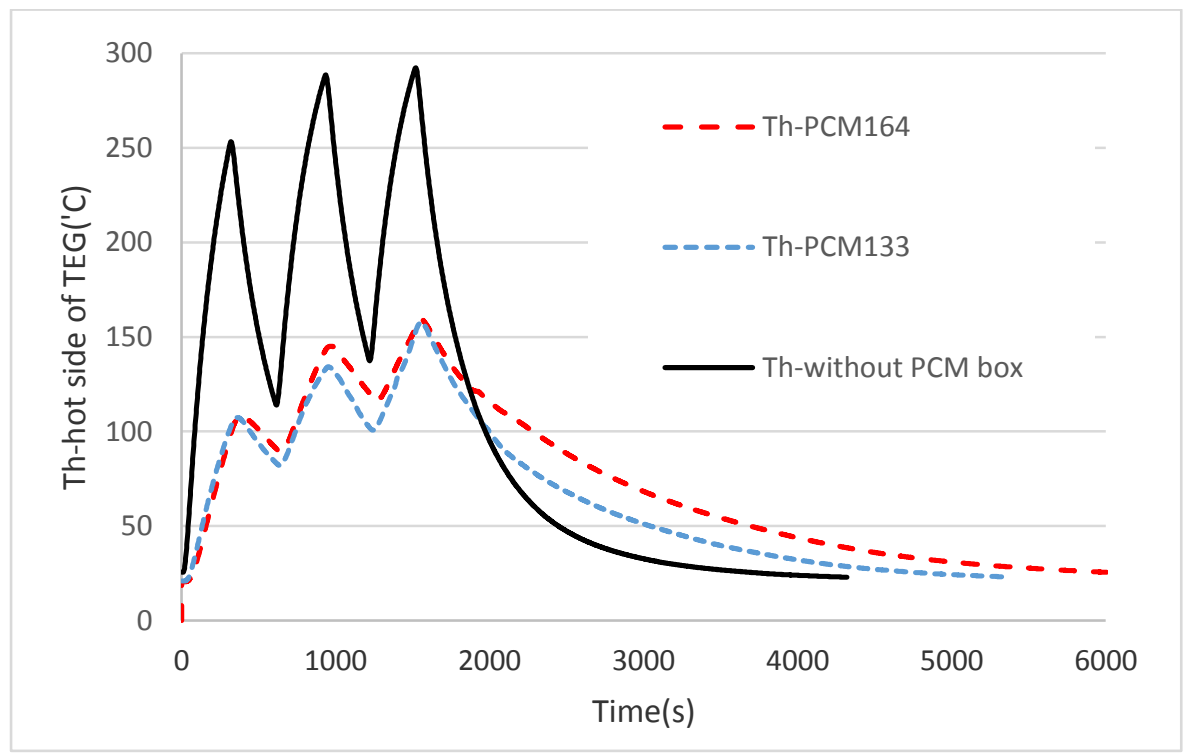

Figure 2. Diagram of hot side temperature of the TEM for three different tests 
$10^{\mathrm{TH}}$ INTERNATIONAL CONFERENCE ON SUSTAINABLE ENERGY AND ENVIRONMENTAL Protection (June $27^{\mathrm{TH}}-30^{\mathrm{TH}}, 2017$, Bled, SLOVENIA), WASTE ENERGY AND MANAGEMENT

S. Ahmadi Atouei, A. Rezaniakolaei, A.Akbar Ranjbar \& L. Aistrup Rosendahl: Protection Of TEG Module at High Temperature Transient Boundary Condition Using Phase Change Materials, an Experimental Investigation

The TEM that was used in the experiments was tuned by the manufacture for optimal hot side operation temperature range of $200-250^{\circ} \mathrm{C}$ and could withstand continuous operating temperatures of $330^{\circ} \mathrm{C}$. With a proper design of PCM box geometry and selection of a suitable PCM, not only it is possible to damp the high temperature fluctuations, it is possible to keep the TEM in range of the optimal operation temperature in the transient boundary conditions.

Figure 3 shows variation of the cold side temperatures of the TEM. Results show that, by using PCM, it is possible to reduce the cooling power and to increase the thermoelectric net power.

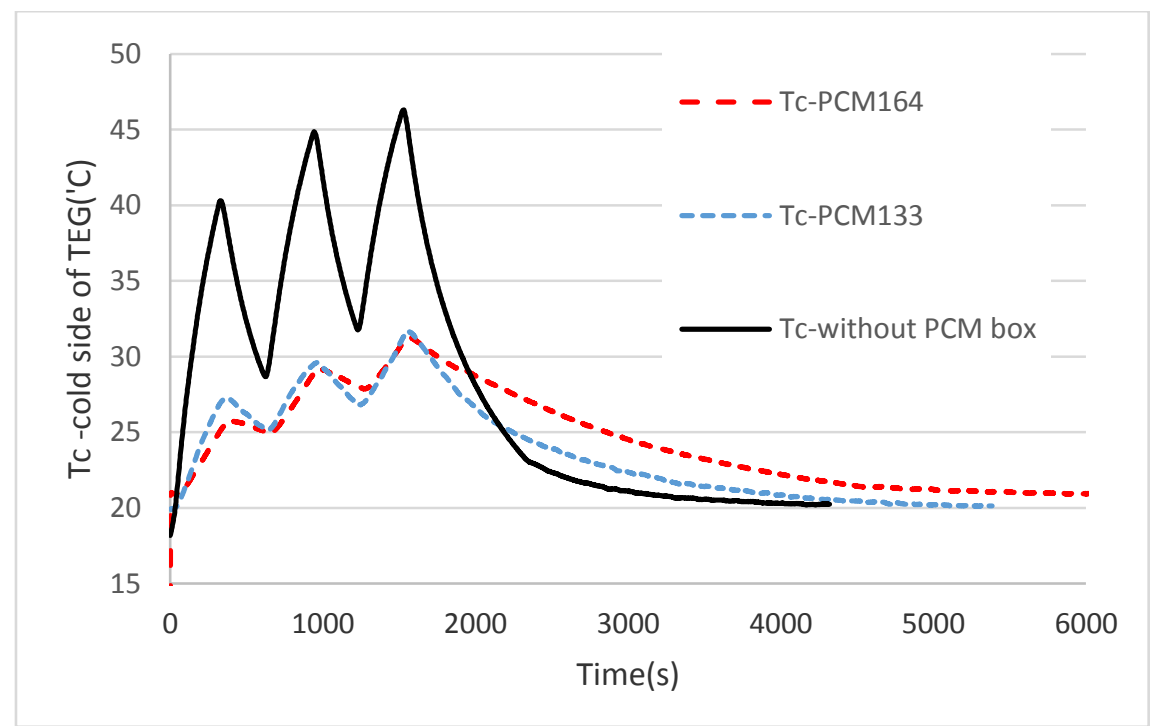

Figure 3. Diagram of cold side temperature of the TEM for three different tests

Open circuit voltage generated by the TEM is shown in the Figure 4. The amount of voltage for the case without the PCM is higher, but with higher fluctuation. It is because of the range of temperature applied to the hot side of the TEM. At this study, design of the system kept the hot side temperature in the range of $100-150^{\circ} \mathrm{C}$ while optimum hot side temperature for the TEG module was between $200-250^{\circ} \mathrm{C}$. Therefore, with a suitable design of the system it is possible to reach the optimum condition and operation in the appropriate range of temperature in the transient condition. The results show that by using PCM in the system it is possible to generate voltage for a longer period after switching off the external heat source. 
S. Ahmadi Atouei, A. Rezaniakolaei, A.Akbar Ranjbar \& L. Aistrup Rosendahl: Protection Of TEG Module at High Temperature Transient Boundary Condition Using Phase Change Materials, an Experimental Investigation

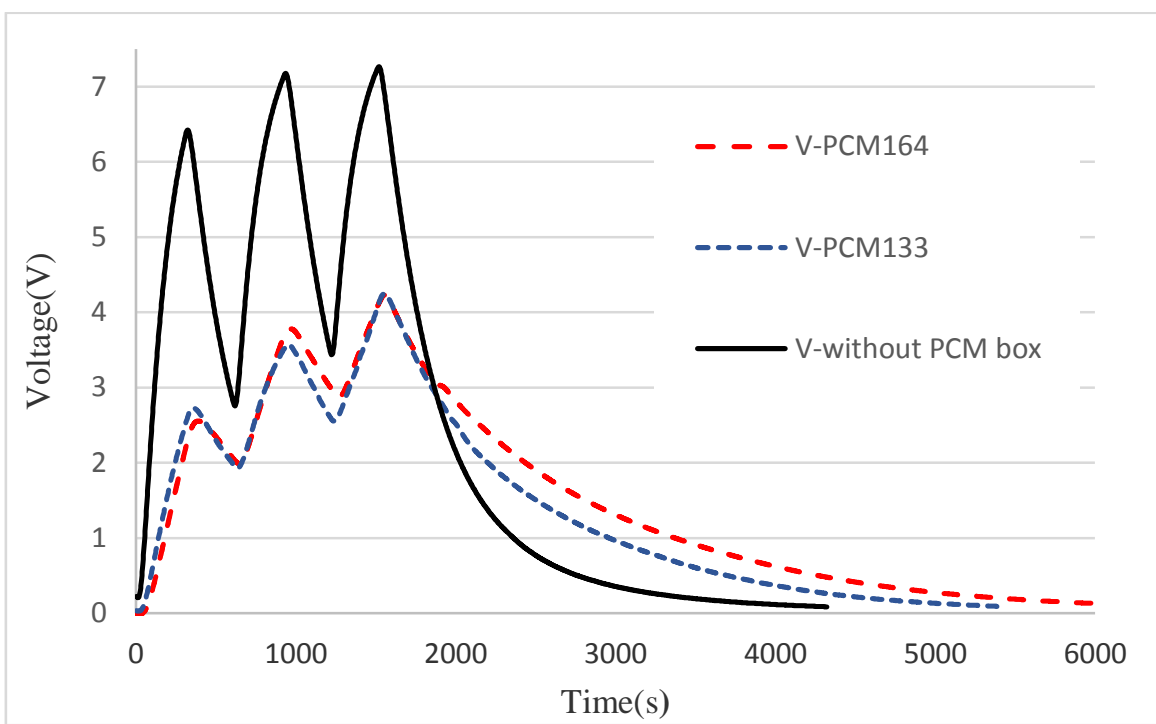

Figure 4. Diagram open circuit voltage generated by TEG for three different tests

\section{5}

\section{Conclusion}

In this study, an experimental investigation is performed to analysis the effect of using phase change materials for protecting the TEM module in the high temperature fluctuations. Three different tests had been done, and the results are presented and compared. The results show that, with a proper design of PCM box and select an appropriate PCM, not only the high temperature fluctuations can be damped, the TEM can operates in the optimum range of temperature for transient boundary conditions. This technique protects the TEM from failure in high pulse of heat flux form the heat source.

\section{References}

[1] D.M. Rowe (Ed.), "CRC Handbook of Thermoelectrics," CRC Press, Boca Raton, FL, 1995.

[2] K.Mizuno,K.Sawada et al, "Development of a thermal buffering device to cope with temperature fluctuations for a thermoelectric power generator," Journal of Electronic Materials, Vol. 41, No. 6, 2012

[3] M. K.Altstedde, F Rinderknecht and H., " Integrating phase-change materials into automotive thermoelectric generators," Journal of Electronic Materials, Vol. 43, No. 6, (2014)

[4] N. R. Jankowski, F. P. McCluskey, "A review of phase change materials for vehicle component thermal buffering," Applied Energy 113 (2014) 1525-1561

[5] K Ismail, M Goncalves, "Thermal performance of a PCM storage unit," Energy Convers Manage 1999;40:115-38 
$10^{\text {TH }}$ INTERNATIONAL CONFERENCE ON SUSTAINABLE ENERGy AND ENVIRONMENTAL

Protection (June $27^{\mathrm{TH}}-30^{\mathrm{TH}}, 2017$, Bled, SLOVEnia), WASte ENERGy AND

MANAGEMENT

S. Ahmadi Atouei, A. Rezaniakolaei, A.Akbar Ranjbar \& L. Aistrup Rosendahl: Protection Of TEG Module at High Temperature Transient Boundary Condition Using Phase Change Materials, an Experimental Investigation

[6] J.P. da Cunha, P. Eames, "Thermal energy storage for low and medium temperature applications using phase change materials - A review," Applied Energy 177 (2016) 227238 



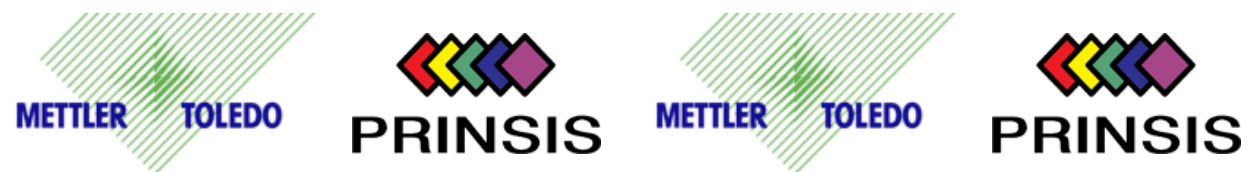

$€$ energetika ljubljana $€$ energetika ljubljana

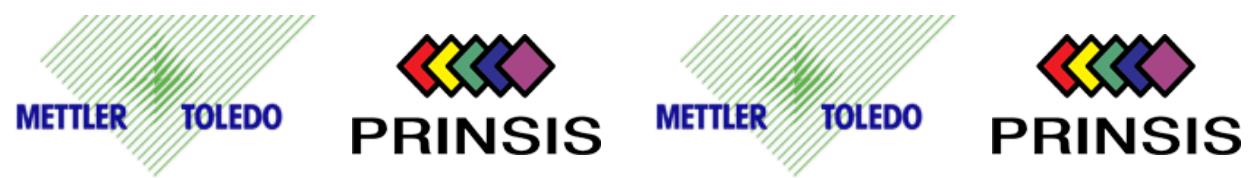

$€$ energetika ljubljana $€$ energetika ljubljana

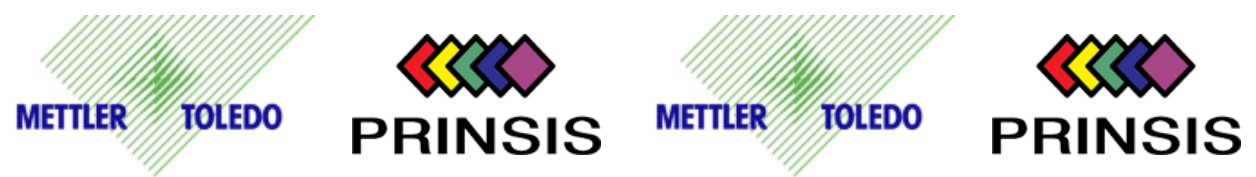

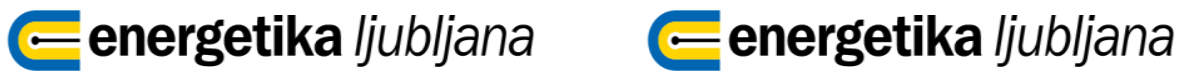

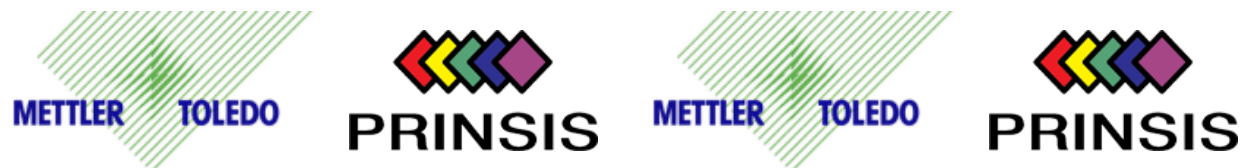

$€$ energetika ljubljana $€$ energetika ljubljana

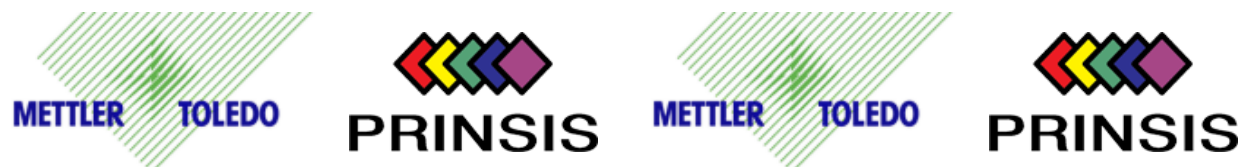

$€$ energetika ljubljana $€$ energetika ljubljana 